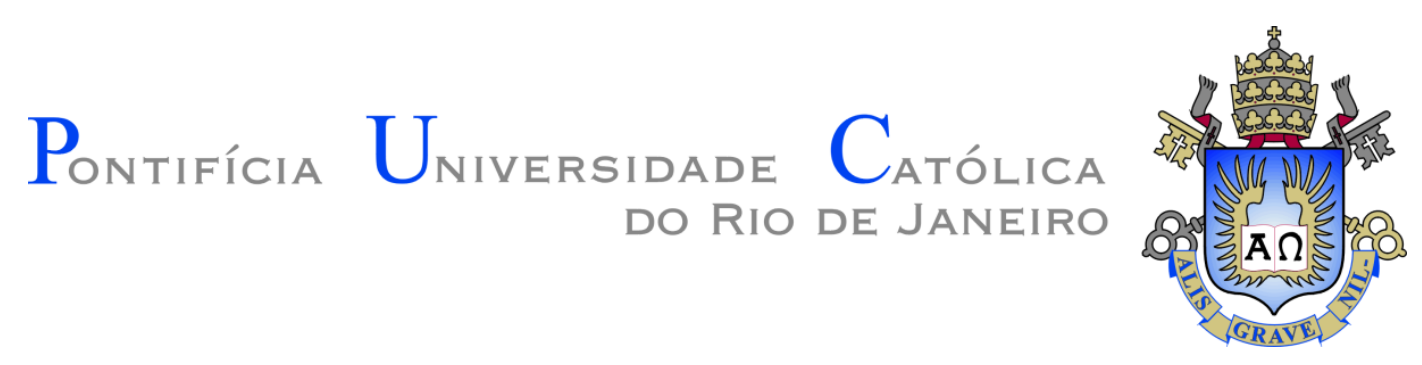

JIVALDO DOS SANTOS FILHO

\title{
O Espírito gera filhos: Estudo exegético de Rm 8,14-17
}

\section{Dissertação de Mestrado}

Dissertação apresentada como requisito parcial para obtenção do grau de Mestre pelo Programa de PósGraduação em Teologia do Departamento de Teologia do Centro de Teologia e Ciências Humanas da PUC-Rio.

Orientador: Prof. Waldecir Gonzaga 


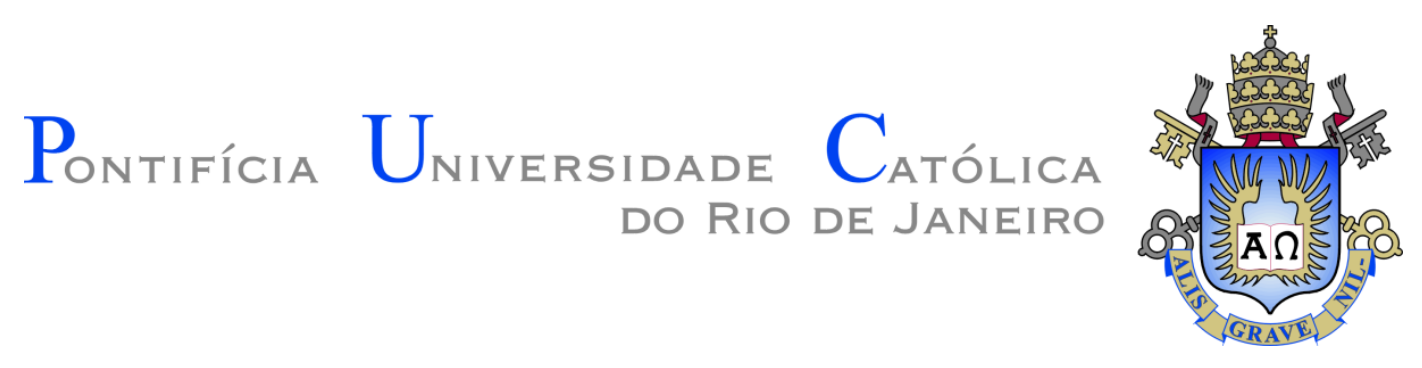

JIVALDO DOS SANTOS FILHO

\section{O Espírito gera filhos: Estudo exegético de Rm 8,14-17}

Dissertação apresentada como requisito parcial para obtenção do grau de Mestre pelo Programa de PósGraduação em Teologia do Departamento de Teologia do Centro de Teologia e Ciências Humanas da PUC-Rio. Aprovada pela Comissão Examinadora abaixo assinada.

Prof. Waldecir Gonzaga

Orientador

Departamento de Teologia - PUC-Rio

Prof. Leonardo Agostini Fernandes

Departamento de Teologia - PUC-Rio

Prof. Romeu Leite Izidório PUC- Campinas

Profa. Denise Berruezo Portinari

Coordenadora Setorial de Pós-Graduação e Pesquisa do

Centro de Teologia e Ciências Humanas - PUC-Rio

Rio de Janeiro, 28 de dezembro de 2017 
Todos os direitos reservados. É proibida a reprodução total ou Parial do trabalho sem autorização da universidade, do autor e do orientador.

\section{Jivaldo dos Santos Filho}

Graduou-se em Filosofia na Faculdade Batista Brasileira em 2011. Graduou-se em Direito na Faculdade de Administração e Negócios de Sergipe em 2015.

Ficha Catalográfica

Santos Filho, Jivaldo dos

O Espírito gera filhos: estudo exegético de Rm 8,14-17 / Jivaldo dos Santos Filho; orientador: Waldecir Gonzaga. - 2017.

$88 \mathrm{f.} ; 30 \mathrm{~cm}$

Dissertação (mestrado)-Pontifícia Universidade Católica do Rio de Janeiro, Departamento de Teologia, 2017.

Inclui referências bibliográficas

1. Teologia - Teses. 2. Paulo. 3. Romanos. 4. Espírito. 5. Filiação. 6. Abba. I. Gonzaga, Waldecir. II. Pontifícia Universidade Católica do Rio de Janeiro. Departamento de Teologia. III. Título.

CDD: 200 


\section{Agradecimentos}

A Deus que é Princípio e Fim, autor da Vida, que iluminando minha vida, e concedendo-me saúde e discernimento ajudou a realizar com grande labuta esta pesquisa.

À minha adorável Mãe, mulher de enorme fé, guerreira incansável, sustentáculo de unidade da minha família, razão da minha insistência acadêmica e presença MATERNA DE DEUS, que nos momentos mais difíceis da minha vida, colocou-me nos braços e lembrou os motivos pelos quais precisamos seguir nos caminhos da vida.

Ao meu Pai, homem inteligente e lutador que, com seu exemplo, orientoume na direção desta etapa importante da minha formação acadêmica.

Ao meu querido tio Renato que com sua presença alegre motivou a minha vida nos momentos de tristeza.

Aos meus filhos João Pedro e Paulo Victor, que mesmo tendo pouca idade e experiência é fonte inspiradora e razão para continuidade de minhas lutas a cada amanhecer. Agradeço à minha sobrinha Elisa Maria que me renova sempre com seu sorriso e pureza nos constantes entraves que enfrentamos.

À minha querida irmã Jeane que, com sua experiência pedagógica e senso materno ouviu minhas angústias e acolheu todas minhas limitações.

A meu irmão Jackson, homem valoroso, que assumi todos os dias com carinho e empenho as responsabilidades mais difíceis da nossa família.

A meu irmão Jadson, homem de fé e inteligente que a cada dia orienta nossa jornada com as palavras santas da Sagradas Escrituras.

Às minhas cunhadas Roseli e Everly, atenciosas e prestativas, sempre preocupadas com as minhas necessidades, nunca mediram esforços para solucionar os problemas que pudessem oferecer dificuldades na minha caminhada.

A Don Stélio e paroquianos de San Rocco, à Ir. Maria Carmem Soler, à Elida e família Vitali e, por fim, em memória, de Inês Alves Mota, Mari Menezes, José Pedro, Francisco de Lima e Dina Vitali.

Ao meu orientador Prof. Dr. Pe. Waldecir Gonzaga pela amizade, compreensão e inclusive pela inteligência prática, lendo todo nosso trabalho por 
diversas vezes, com louvor, paciência e enorme conteúdo acadêmico, orientou-me na elaboração deste estudo.

Ao professor Coordenador da Pós-graduação Prof. Dr. Pe. Abimar que sempre disponível para aprimoramento do curso, nos acolhe na Instituição com grande alegria concedendo todo apoio acadêmico e humano para o bom êxito da nossa formação.

Aos professores Prof. Dr. Leonardo Agostini e a Prof ${ }^{\mathbf{a}}$. Dr ${ }^{\mathbf{a}}$. Maria de Lourdes Corrêa Lima que, com louvor durante os períodos acadêmicos estudados nesta Instituição, contribuíram com seus ensinamentos e exemplos ao arcabouço teológico bíblico que nos foi proporcionado.

Ao Prof. Dr. Pe. Romeu pela fraternidade, por ter participado da banca examinadora e contribuído para minha formação.

Ao Prof. Dr. Pe. Otácio, Prof. Dr. Pe. Heitor, Prof. Dr. Pe. André, Pe. Mário e Pe. Bruno e ajuda concedida para a realização deste projeto acadêmico.

Ao Arcebispo da Arquidiocese de Nitéroi Dom José Francisco e seu Auxiliar Dom Luiz Antônio Lopes Ricci, à Nilze Mara, Cristiane, Angela, Klécio, Alexandre e família, Nilo e família, Adelma e família na pessoa do meu irmão de caminhada na fé Pe. Leandro Azevedo e sua família que me acolheram em sua Paróquia com espírito fraterno, concedendo todo apoio necessário para minha estadia no Rio de Janeiro e demonstrando com quão grande é a beleza da comunhão na Igreja.

À CAPES e à PUC-Rio pelo auxílio financeiro sem os quais não seria possível a realização desta pesquisa.

Aos meus nobres colegas Doaldo, Leniziane, Bruno, Rafael, Marcelo, Cláudio e Pe. Fábio companheiros de jornada e de estudos acadêmicos.

A Jorge dos Santos e Nilton do Rosário Vollotão, membros da Coordenação Central de Pós-graduação e Pesquisa por todo apoio e disponibilidade dispensado indistintamente aos alunos da PUC-Rio.

Por fim, agradeço aos funcionários do Departamento de Teologia e de Direito, aos funcionários do setor médico, no qual frequentei nos momentos de crise de saúde e a toda família PUC-Rio pela estrutura, disponibilidade e auxilio ao qual me foram dados durante meus estudos na Instituição ao longo deste ano 2017, ano que cursei os créditos, fiz o exame complexivo, escrevi este texto da dissertação e fui examinado pela banca. 


\section{Resumo}

Dos Santos Filho, Jivaldo; Gonzaga, Waldecir. O Espírito gera filhos: Estudo exegético de Rm 8,14-17. Rio de Janeiro, 2017. 88p. Dissertação de Mestrado - Departamento de Teologia, Pontifícia Universidade Católica do Rio de Janeiro.

Dentro do epistolário paulino a Carta aos Romanos é consagrada por vários estudiosos como o testemunho maior da missão do araldo Paulo. Composta por dezesseis capítulos, ela traz em seu bojo, entre outros, temas relevantes como a justificação pela fé, a Lei, a vida no Espírito e a filiação divina. O centro desta Epístola encontra-se aparentemente no capítulo 8 onde se desenvolve um tratado sobre o $\pi v \varepsilon v \tilde{\mu} \alpha$. A presente pesquisa desenvolverá um estudo na unidade literária de $\mathrm{Rm}$ 8,14-17 sob a ótica do acolhimento da vida no Espírito que, consequentemente, gera filhos de Deus, tornando o homem herdeiro do Pai e coherdeiro de Cristo. Todavia, vale salientar que o mistério da filiação divina não era estranho ao povo escolhido, pois Deus era considerado o Pai das Nações e de tudo que fora criado no céu e na terra conforme a TANAK (Gn 1,1-2,4a). Entretanto, com Cristo, é inaugurado uma nova perspectiva sem precedente na história da salvação. Por este viés, essa temática sempre será atual, haja vista que os textos neotestamentários têm como meta maior a epifania da pessoa de Jesus Cristo, Filho de Deus, que em si é a plenitude da revelação do Pai na vida do cristão (Jo 12,45; 14,6-11). Desta forma, em Cristo por intermédio do Espírito Santo, foi-nos dado a possibilidade de participar da vida divina, que no Batismo recebemos e nos permite a intimidade filial para gritarmos $A b b a$ Pai. Por fim, toda essa reflexão somente nos foi possível pela riqueza que encontramos nas ferramentas utilizadas, proporcionadas pelos métodos histórico-crítico, retórico e a vasta contribuição literária disposta em dicionários e comentários exegéticos.

\section{Palavras - chave}

Paulo; Romanos; Espírito; Filiação; Abba. 


\section{Abstract}

Dos Santos Filho, Jivaldo; Gonzaga, Waldecir (Advisor). The Spirit begets children: Exegetical study of Romans 8, 14-17. Rio de Janeiro, 2017. 88p. Disssertação de Mestrado - Departamento de Teologia, Pontifícia Universidade Católica do Rio de Janeiro.

Within the Pauline epistolary the Letter to the Romans is consecrated by several scholars as the greatest testimony of the mission of Araldo Paul. Comprising sixteen chapters, it brings in its bulge, among others, relevant themes such as justification by faith, the Law, life in the Spirit and divine filiation. The center of this Epistle is apparently in chapter 8 where a treatise on $\pi v \varepsilon v \tilde{\mu \alpha}$ is developed. The present research will develop a study in the literary unit of Rm 8,14-17 from the viewpoint of the reception of the life in the Spirit that, consequently, generates children of God, making the man heir of the Father and co-heir of Christ. However, it is worth noting that the mystery of the divine sonship was not foreign to the chosen people, for God was considered to be the Father of Nations and everything created in heaven and on earth according to Tanak (Gen 1,1-2,4a). However, with Christ, an unprecedented new perspective is inaugurated in the history of salvation. By this bias, this theme will always be current, since the New Testament texts have as their main goal the epiphany of the person of Jesus Christ, the Son of God, who in himself is the fullness of the revelation of the Father in the life of the Christian (John 12,45; 14,6-11). In this way, in Christ through the Holy Spirit, we were given the possibility to participate in the divine life, which we received in Baptism and allow us the filial intimacy to shout Abba Father. Finally, all this reflection was only possible to us by wealth which we find in the tools used, provided by historicalcritical, rhetorical methods and the vast literary contribution set forth in exegetical dictionaries and commentaries.

\section{Keywords}

Paul; Romans; Spirit; Affiliation; Abba. 


\section{Sumário}

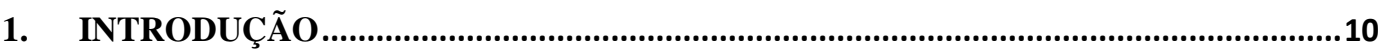

2. QUESTÕES PRELIMINARES DA CARTA AOS ROMANOS..................................13

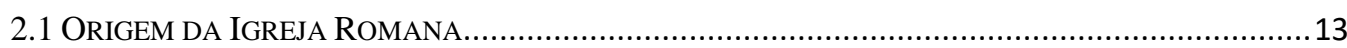

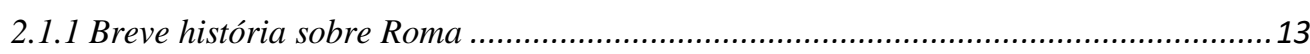

2.1.2 Momento histórico-social-cultural-religioso-econômico.............................................14

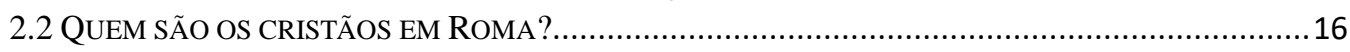

2.2.1. Autoria, destinatário, ocasião, data, lugar de composição e autor.............................18

2.2.1.1. Paulo, apóstolo e autor da carta ........................................................................................ 18

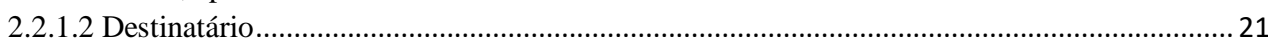

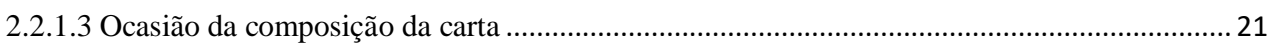

2.2.1.4 Data e lugar da composição ............................................................................................... 22

2.2.2 Significado da Carta aos Romanos.....................................................................23

3. DISPOSIÇÃO RETÓRICA, TEXTO E CRÍTICA TEXTUAL .......................................25

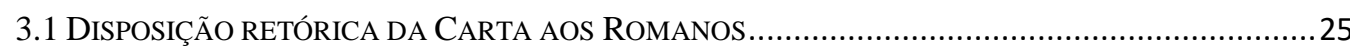

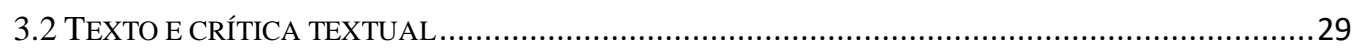

3.3 DiSPOSIÇÃo RETÓRICA DE RM 8,14-17 NO CONTEXTO IMEDIATO DE RM 8 ……....................32

3.4 UM TEMA DESENVOLVIDO EM RM 8,14-17 E CRUCIAL NA CARTA AOS GÁLATAS ....................34

4. COMENTÁRIO EXEGÉTICO DE RM 8,14-17 .......................................................37

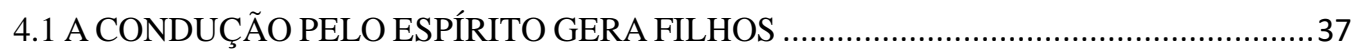

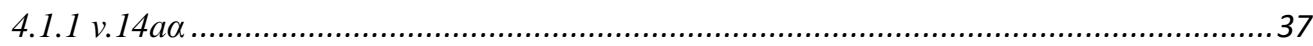

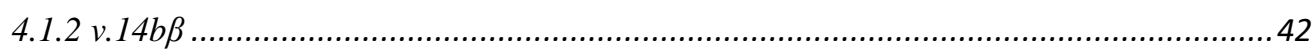

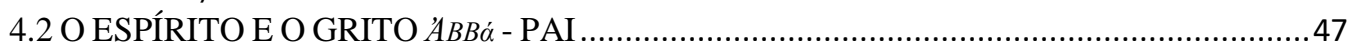

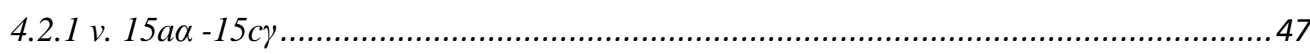

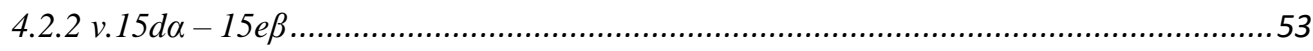

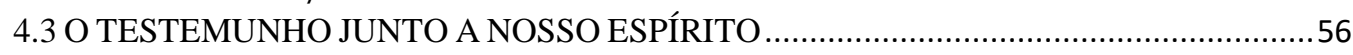

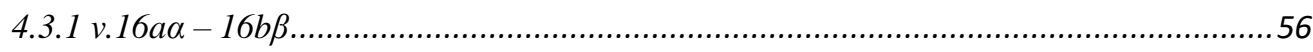

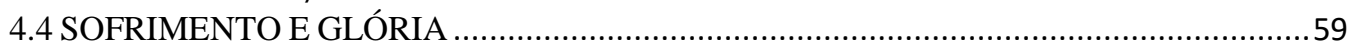

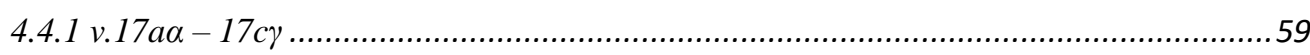

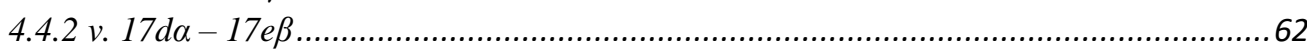

5. SÍNTESE TEOLÓGICA DE RM 8,14-17 ..................................................................65

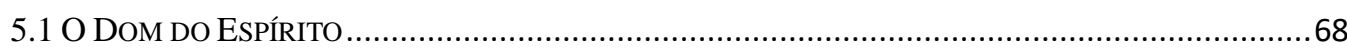

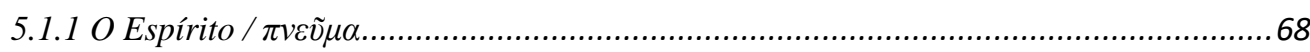

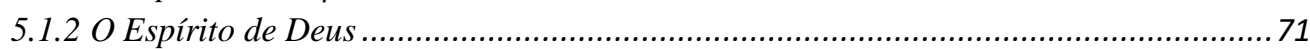

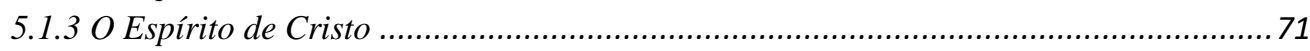

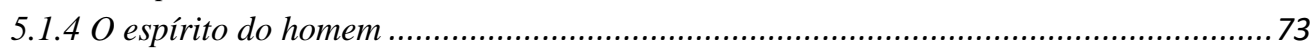

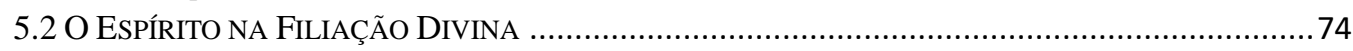

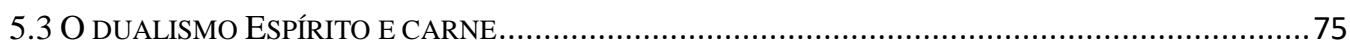

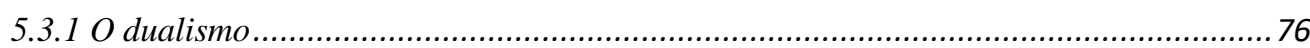

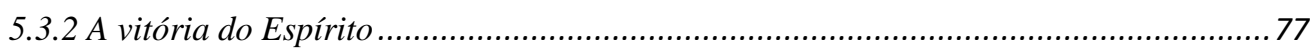

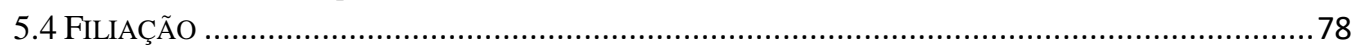

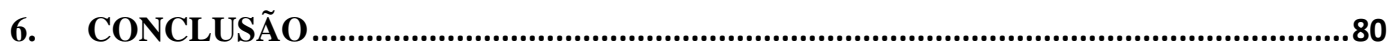

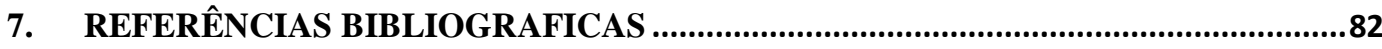

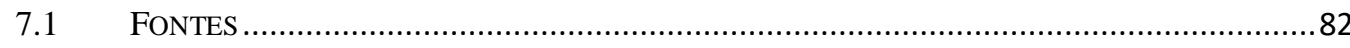

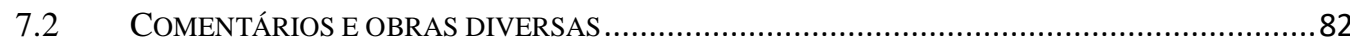




\section{Siglas e abreviações}

\begin{tabular}{|c|c|}
\hline a.C. & Antes de Cristo \\
\hline AT & Antigo Testamento, Antico Testamento \\
\hline et al. & Indicação para citação de mais de três autores \\
\hline $\mathrm{CIC}$ & Catecismo da Igreja Católica \\
\hline d.C. & depois de Cristo \\
\hline DCBNT & Dizionario dei Concetti Biblici del NT Bologna: EDB, 1976. \\
\hline DENT & $\begin{array}{l}\text { Dizionario Esegetico del NT Brescia: Paideia Editrice, } \\
1995,2004^{2} \text {. }\end{array}$ \\
\hline DPL & $\begin{array}{l}\text { Dizionario di Paolo e delle sue Lettere. Torino: San Paolo, } \\
1999 .\end{array}$ \\
\hline EB & Estudios Bíblicos \\
\hline ed. & Edição \\
\hline $\mathrm{EDB}$ & Edizioni Dehoniane Bologna \\
\hline etc. & Et coetera \\
\hline GCB & Grande Comentário Bíblico \\
\hline GLNT & Grande Lessico dell'AT Brescia: Paideia Editrice, 2003. \\
\hline IEB & Intoducción al Estudio de la Biblia \\
\hline LBNT & I Libri Biblici Nuovo Testamento \\
\hline NewDocs & New documents Illustrating Early Christianity \\
\hline NT & Novo Testamento; Nuovo Testamento; Nuevo Testamento \\
\hline p. & Página \\
\hline$P D B$ & $\begin{array}{l}\text { Piccolo Dizionario Biblico. Cinisello Balsamo: San Paolo, } \\
1988,1997^{7} \text {. }\end{array}$ \\
\hline$P S V$ & Parola Spirito e Vita \\
\hline SB & Studi biblici. Brescia 1971 ff. \\
\hline ss. & Seguintes \\
\hline TOB & Traduction Oecuménique de la Bible \\
\hline v. & Versículo \\
\hline VTB & $\begin{array}{l}\text { Vocabulario de Teología Bíblica. Barcelona: Herder, 1965, } \\
1996^{17} \text {. }\end{array}$ \\
\hline WBC & Word Biblical Commentary \\
\hline
\end{tabular}




\section{Introdução}

A exortação feita pelo apóstolo Paulo na Carta aos Romanos, em nossa perícope Rm 8,14-17, chama a nossa atenção para a realidade da filiação, pela qual o povo de Deus foi chamado a uma relação de intimidade com o Pai na plenitude dos tempos, por intermédio do seu único Filho Jesus Cristo.

A filiação para o povo de Deus do antigo Israel não era uma realidade nova. As Escrituras já relatavam a paternidade de Deus como Pai das nações (cf. Gn 1,2631; S1 24,1; Sl 89,12) entretanto, também de indivíduos como Davi (S1 89,27),

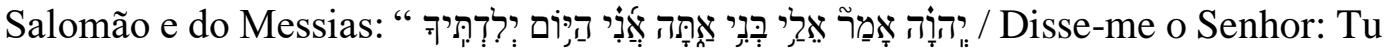
és meu Filho, eu hoje te gerei" (S1 2,7; cf. At 13,33; Hb 1,5; 5,5).

Da mesma forma, o apóstolo Paulo tinha consciência de que a filiação não tinha raízes novas. Contudo, foi após a experiência a caminho de Damasco, que se manifestou se a filiação de Jesus como realidade que não havia precedentes porque se diferenciaria da revelada nas Escrituras ao povo judeu. Essa experiência o

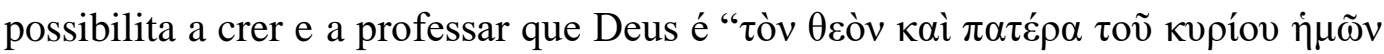
'I 1,3) e assim sendo, o ressuscita dos mortos (Gl 1,1). A ideia da paternidade de Deus a Jesus que revela a natureza do nosso Salvador, também é manifestada nos Evangelhos de acordo, por exemplo, com os eventos do Jordão (onde há o Batismo de Jesus, Mt 3,17; Mc 1,11; Lc 3,22) e da Transfiguração (Mt 17,5; Mc 9,7 e Lc $9,35)$.

Com Jesus, Paulo adquire uma nova visão da humana relação com Deus, e faz questão de expor, através de suas cartas, como se vê com clareza em sua mensagem à Igreja da Galácia, como também em outras cartas, em que saúda os

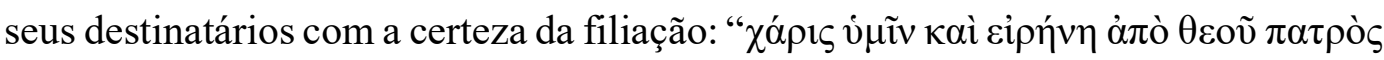

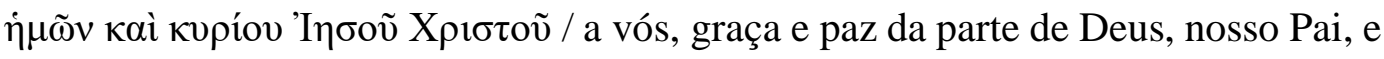
da parte do Senhor Jesus Cristo" (Gl 1,3). Assim, deixa evidente na sua saudação que Deus também é nosso Pai. A Igreja corrobora essa verdade, que também o apóstolo Pedro já havia testemunhado (2Pd 1,16-18). Essa ideia também é confirmada pelo $\mathrm{n}^{\circ} .460$ do Catecismo da Igreja Católica (CIC): 
$\mathrm{O}$ verbo se fez carne para torna-nos participantes da natureza divina $(2 \mathrm{Pd} 1,4)$. Santo Irineu declara: "Pois esta é a razão pela qual o Verbo se fez homem, e o Filho de Deus, Filho do homem: é para que o homem entrando em comunhão com o Verbo e recebendo assim a filiação divina, se torne fillho de Deus"; Também Santo Tomás de Aquino afirma: Unigenitus Dei Filius, suae divinitatis volens nos esse participes, naturam mostram assumpsit, ut homines deos faceret factus homo - "O Filho Unigênito de Deus, querendo-nos participantes da sua divindade, assumiu a nossa natureza para que aquele que se fez homem, dos homens fizesse deuses".

Duas são as motivações que levaram ao desenvolvimento do devido estudo: a primeira é um ato de gratidão ao Bom Deus por nos permitir participar da sua vida divina; e a segunda, é de cunho científico que têm como fundamental importância o caminho da reflexão Bíblica, pelo estudo do texto, com sua história e sua teologia. E assim, o objetivo geral deste trabalho é demonstrar que o homem passa a ser filho de Deus por meio do seu único Filho Jesus Cristo no Espírito Santo na adesão pela Fé.

A nossa dissertação usufruirá da metodologia Retórica Literária que é um particular instrumento do mundo Apostólico de Paulo, do Método Histórico Crítico, do estudo exegético dos termos que compõem a perícope estudada e da vasta publicação de comentadores da obra paulina.

A presente dissertação está dividida em seis capítulos: partindo da delimitação do nosso texto de $\mathrm{Rm} 8,14-17$, no primeiro capítulo faremos uma introdução na qual será exposto o panorama geral deste trabalho com suas motivações e divisões; no segundo capítulo exporemos as questões preliminares que compõem a Carta aos Romanos como o contexto histórico do mundo Romano e a pessoa de Paulo, para que, os conhecendo possamos ter uma melhor compreensão do destinatário, isto é, quem são, o porquê do envio da Carta e qual o seu significado, e com isto usufruirmos melhor da sua mensagem e termos em vista as dificuldades que o apóstolo enfrentou para cumprir sua missão de araldo; no terceiro capítulo, de caráter textual, apresentaremos a disposição retórica, sua composição, a perícope em si com uma tradução sugerida e a crítica textual realizada a partir do aparato crítico encontrado na $28^{\text {a }}$ edição de Nestle-Aland; no quarto capítulo partindo da metodologia supra citada tentaremos exegeticamente colher o máximo possível da mensagem do texto na língua original, observando o que Paulo disse para o povo daquela época e o que isso quer dizer atualmente para nós com seu aspecto teológico-bíblico; o quinto capítulo de cunho teológico, 
privilegiará os temas centrais desta dissertação e que são ricos à Carta aos Romanos,

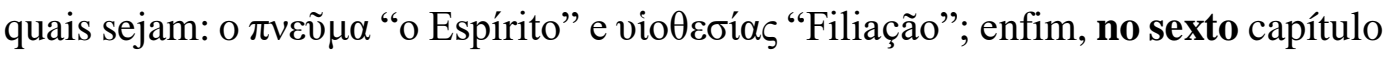
será exposto o entendimento que obtivemos após as jornadas árduas e satisfatórias do estudo realizado na obra magna do apóstolo Paulo. 


\section{Questões preliminares da Carta aos Romanos}

A Carta aos Romanos é tida como o escrito mais importante ${ }^{1}$ de todo epistolário paulino, não somente por ser grande, mas sobretudo porque é a única na qual o apóstolo desenvolve um discurso teológico bastante completo e sistemático, e assim desde o início do cristianismo foi constituída e utilizada. ${ }^{2}$

A partir de agora tentaremos seguir a dinâmica escriturária de cada escritor que ao enviar uma mensagem para um destinatário concreto, já tem consigo um certo conhecimento da realidade pela qual deve ser acolhida tal mensagem. Assim Paulo, apesar de não conhecer pessoalmente a comunidade de Roma, envia seu grande testamento para o anúncio da boa nova: Jesus Cristo.

\subsection{Origem da Igreja Romana \\ 2.1.1 Breve história sobre Roma}

Conforme Fitzmyer, a cidade de Roma foi fundada por descendentes de Enea, Rômulo e Remo aos 23 de abril de 753 a.C. "Roma nasce da união dos Latinos (sediada no Palatino) e dos Sabinos (sediada no Esquilino, no Veminal e no Quirinal), e que inicialmente foi beneficiada por um regime monárquico (os setes reis de Roma)"3.

No princípio era uma vila de pastores que se tornou prolongamento de Alba Longa. Todavia, com sua posição privilegiada na Itália central, sendo vizinha do mar e sobre a foz do rio Tibre, sua população cresce desmedidamente superando os povos vizinhos. Para resumir, vejamos um breve panorama da história de Roma ${ }^{4}$ :

\footnotetext{
1 J.D.G. DUNN. Lettera ai Romani. In: G.F. HAWTHORNE; R.P. MARTIN; D.G. REID. Dizionario di Paolo e delle sue Lettere. Cinisello Balsamo: San Paolo Edizioni, 2000, p. 1353.

${ }^{2}$ G. BARBAGLIO. La persona e l'opera di Paolo. In: A. SACCHI et al. ed. Lettere Paoline e altre Lettere. LCSB 6. Torino: Elledici, 1996, p. 54: "Ad alcuni suoi passaggi alludono già probabilmente la prima lettera di Pietro (Rom 13,1-7 con 1Pe 2,13-117) e con maggiore chiarezza Clemente Romano (1Cor 35,5-6) e Ignazio di Antiochia"; J. SANCHEZ BOSCH. Escritos paulinos. IEB 7, Estalla (Navarra): Editorial Verbo Divino, 1998, p. 170.

${ }^{3}$ J.A. FITZMYER. Lettera ai Romani: Commentario critico-teologico. Casale Monferrato: Edizioni Piemme, 1999, p. 55.

${ }^{4}$ J.A. FITZMYER. Lettera ai Romani: La Lettera ai Romani: Commentario critico-teologico, p. 55; D.E. AUNE. Imperatori Romani. In: G.F. HAWTHORNE; R.P. MARTIN; D.G. REID. Dizionario di Paolo e delle sue Lettere. Cinisello Balsamo: San Paolo Edizioni, 2000, p. 847-848.
} 
- Em 753 a.C. Roma foi fundada.

-Em 510 a.C. fim da Monarquia.

- Em 275 a.C. Roma obtém o controle de toda Itália.

- Em 241 a.C. Roma se movimenta para a guerra e conquista as províncias da Sicília; em 238 a.C. as províncias da Sardenha; em 206 a.C. da Espanha; em 148 a.C. a Macedônia; em 146 a.C. a província de Corinto.

-Entre 135-132 a.C. e 103-101 a.C. Roma é marcada por rebeliões e guerras dos escravos.

-Em 60 a.C. Roma passa a ser governada por um grupo de generais: Pompeu, Crasso e Julio César.

-Em 44 a.C. Julio César é assassinado e com isso, Marco Antônio e César Otávio assumem o poder.

-Em 31 a. C. morre Marco Antônio e César Otávio passa a ser o único senhor do mundo romano.

- Com o passar do tempo, em meados de 27 a.C. o senado confere a César Otávio o título de Augustus proporcionando a soberania total no governo do Império.

- Em torno ao ano 14 a.C. César Otávio morre e seus sucessores assumem o poder.

-Entre os anos 14-37 d.C. Roma é governada por Tibério César.

-Entre os anos 37-41 d.C. é sucedido por Caio Caligula que chega ao poder.

- Entre os anos 41-54 d.C. Roma é governada por Claúdio.

- Entre os anos de 54-68 d.C. é governada por Nero. Vale ressasltar que neste período houve a morte dos apóstolos Tiago menor por volta de 62 d.C., Pedro por volta de 64 d.C, Paulo por volta de 67 d.C. e Judas Tadeu por volta de 70 d.C.

\subsubsection{Momento histórico-social-cultural-religioso-econômico}

A Carta aos Romanos é destinada aos cristãos de Roma, que era a capital do Império Romano ao tempo da composição do documento. Ao lado de Alexandria (Egito), Corinto (Grécia) e Antioquia (Síria), já no séc. I d.C. Roma era uma das cidades mais importantes do mundo mediterrâneo. Como capital do Império, 
dominava a zona oriental do Mediterrâneo, onde o cristianismo havia encontrado um terreno propício no qual pôde estabelecer raízes.

No início da era cristã a cidade de Roma tinha sete colinas e uma média de 1(um) milhão de habitantes ${ }^{5}$. A maioria desses habitantes era constituída por plebeus, libertos ou escravos. Muitos desses eram imigrantes que há pouco tempo tinham chegado à capital do Império, outros eram prisioneiros de guerra ou descendentes deles. Já no alto da escala social estava a aristocracia senatorial apesar de que crescia o poder e influxo dos cavaleiros.

Roma, enquanto capital do Império, constituía o centro do poder (Imperador e Senado). Por um lado, dali partiam as decisões para todo o Império, e se concentrava toda riqueza da Província. E por outro, como todo grande centro também nela se encontravam grandes contradições como: miséria, pobreza, violência, corrupção, problemas no campo da moral sexual, ódio, etc.

Religiosamente falando, Roma era uma cidade tolerante ao culto oriental, na medida que seus integrantes respeitassem a ordem pública. Oficialmente, colocavase uma certa evidência sobre a divindade (Giove, Vênus, Vesta). Também se dava grande importância do culto ao imperador ${ }^{6}$ e a inclinação à superstição.

No I séc. d.C. Roma já era uma cidade de alto nível cultural ${ }^{7}$. Vinham para ela ilustres mestres dos reinos existentes na época, como filósofos, artistas, escritores, gramáticos, matemáticos, astrônomos, médicos. Entretanto, infelizmente esse grande arcabouço cultural era destinado para poucos da população.

Os hebreus constituíam uma parcela considerável da população, cerca de 40.000 habitantes $^{8}$. Uns grupos eram descendestes de uma parte que há séculos atrás viera para Roma. Outra parte chegou depois do ano 63 a.C., ano no qual Pompeu

\footnotetext{
${ }^{5}$ M. REASONER. Roma e il cristianesimo romano. In: G.F. HAWTHORNE; R.P. MARTIN; D.G. REID. Dizionario di Paolo e delle sue Lettere. Cinisello Balsamo: San Paolo Edizioni, 2000, p. 1345. ${ }^{6}$ M. REASONER. Roma e il cristianesimo romano. In: G.F. HAWTHORNE; R.P. MARTIN; D.G. REID. Dizionario di Paolo e delle sue Lettere, p. 1346: "È importante tener presente che la religione romana era strettamente legata al regime politico di Roma. I sacerdoti di questa religione di Stato erano consiglieri del Senato".

${ }^{7}$ M. REASONER. Roma e il cristianesimo romano. In: G.F. HAWTHORNE; R.P. MARTIN; D.G. REID. Dizionario di Paolo e delle sue Lettere, p. 1345: "Nel I secolo d.C. Roma atirava gente da ogni angolo dell' impero, e anche da 27 a.C. - 14 d.C.) per mantenere l'ordine in città si erano creati un corpo di polizia urbana (cohortes urbanae) e un corpo di vigili del fuoco (vigiles). Al pari dei grandi centri urbani oggi, Roma all'epoca dell'impero era una città degna di essere visitata. Affermando che già più volte aveva pensato di visitare i cristiani di Roma, prima di scrivere loro la sua lettera (Rom 1,13), Paolo dice quello che avrebbe detto qualsiasi abitante delle province prima di fare i suoi ultimi preparativi per um viaggio a Roma".

${ }^{8}$ M. REASONER. Roma e il cristianesimo romano. In: G.F. HAWTHORNE; R.P. MARTIN; D.G. REID. Dizionario di Paolo e delle sue Lettere, p. 1346.
} 
conquistou a Palestina e levou consigo para Roma muitos prisioneiros hebreus. Eram várias comunidades autônomas que socialmente pertenciam à classe baixa, $\mathrm{e}$ tinham um estreito relacionamento tanto político quanto cultural e religioso com Jerusalém.

Foi no Império de Augusto que em Roma os judeus conseguiram seus direitos fixados e confirmados, quais sejam: a prática da própria religião, permissão para não participar dos cultos pagãos, autorização para enviar o Didracma ${ }^{9}$ anual ao tempo de Jerusalém.

No ano 49 d.C. os judeus foram expulsos de Roma por mandato do Imperador Cláudio, todavia, com sua morte no ano 54 foi permitido aos hebreus retornarem, graças a Popea que se torna para eles uma grande fonte de influência no Império.

\subsection{Quem são os cristãos em Roma?}

Segundo Penna ${ }^{10}$, quando Paulo escreveu a Carta aos Romanos já existia há muito tempo cristãos ${ }^{11}$ naquela cidade, conforme se deduz indiretamente do texto retirado de $\mathrm{Rm}$ 15,23. Contudo, as circunstâncias do nascimento da nova fé na capital do Império são caracterizadas por algumas incertezas:

- a notícia mais antiga sobre a presença dos cristãos em Roma devemos ao grande historiador pagão Tácito, que, escrevendo pouco depois de 115, narra o suplício sofrido por eles a mando de Nero, após o incêndio de julho de 64 d.C.;

- a notícia mais antiga e explícita sobre a origem dos cristãos em Roma vem do cristianismo com Irineu, bispo de Lion, o qual proclamava em meados do

\footnotetext{
${ }^{9}$ M. MAPILA. Glosarios de numismática antiga. In: http://www.tesorillo.com/roma/1tipos.htm\#D, 2017, [acesso em: 11/10/2017]. "La didracma o doble dracma, era una moneda de plata, llamada también 'estátera', usada por los griegos. Los romanos encargaron a algunas ciudades de la Magna Grecia la acuñación de sus primeras monedas de plata a comienzos del siglo III a.C., y luego las acuñaron ellos mismos, tal vez desde mediados de ese siglo. La didracma circuló aproximadamente entre los años 280 y 211 a.C. y sirvió de precedente para la acuñación del denario, a finales del siglo III a.C."

${ }^{10}$ R. PENNA. Lettera ai Romani: Rm 1-5 (I). Scritti delle origini Cristiane 6. Bologna: Edizioni Dehoniane Bologna, 2004, p. 21.

${ }^{11}$ G. RICCIOTTI. Paolo Apostolo: Biografia con Introduzione Crítica. Roma: Coletti Editore, 1958, p. 386: "A Roma, in realtà, il cristianesimo era penetrato da vari anni. I suoi precisi inizi ci sfuggono, ma indubbiamente non erano stati discepoli di Paolo i primi evangelizzatori dela città dei Cesari”.
} 
séc. II que a Igreja em Roma foi fundada e obteve estabilidade por causa de Pedro e Paulo;

Com relação à fundação da comunidade não temos nada de preciso somente algumas hipóteses como:

- fundada pelos hebreus de Roma (At 2,20), presentes em Jerusalém durante a Festa de Pentecostes e convertidos à fé em Jesus por intermédio da pregação de Pedro mais ou menos no ano 30 d.C.;

- fundada por alguns hebreus ou pagãos como fruto espontâneo da mobilidade de pessoas e ideias que atravessavam o Mediterrâneo e chegavam em Roma. Neste caso se hipotiza a fundação da comunidade mais ou menos em torno dos anos 40 d.C.;

Enfim, desta forma, se por uma parte podemos intuir que a população era

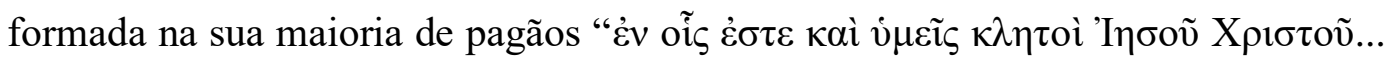

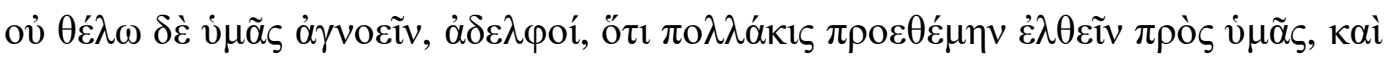

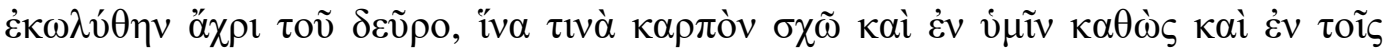

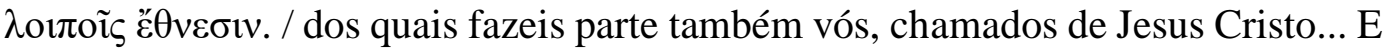
não escondo, irmãos, que muitas vezes me propus ir ter convosco e fui impedido até agora para colher algum fruto também entre vós, como entre os gentios (Rm 1,6.13; cf. Rm 11,13; 15,16) $)^{12}$, por outra parte, lendo a Carta aos Romanos descobre-se uma forte presença de Judeus cristãos (Rm 2,1-24; 3,9.29-30; 4,1; 7,1; 9-11; 13-16).

\footnotetext{
${ }^{12}$ M. REASONER. Roma e il cristianesimo romano. In: G.F. HAWTHORNE; R.P. MARTIN; D.G. REID. Dizionario di Paolo e delle sue Lettere, p. 1345: Com relação a pluralidade étnica de Roma: "A cominciare almeno dal III secolo a.C., Roma divenuta un centro d'attrazione per gente di estrazione etnica diversa. L'immigrazione dalle province dell'Italia e della Grecia, avvenuta all'epoca della repubblica, fu offuscata all'inizio dell'impero da quella di genti provenienti dalla Siria, dall'Asia Minore (Turchia odierna), dall'Egito, dall'Africa, dalla Spagna e più tardi anche dalla Gallia e dalla Germania.(...) Secondo alcuni storici, prendendo spunto da At 2,10 e dal decreto di espulsione di Claudio (anno 49), hanno ipotizzato che prima dell'espulsione la comunità cristiana di Roma era nella maggioranza giudaica, dopo la espulsione, da étnico-cristiani."
} 
2.2.1. Autoria, destinatário, ocasião, data, lugar de composição e autor 2.2.1.1. Paulo, apóstolo e autor da carta ${ }^{13}$

A vida de Paulo pode ser reconstruída em base a duas fontes essências: as Cartas e os Atos dos Apóstolos (At 7,58; 8,1-3; 9,1-30; 11,25-30; 12,25; 13,1-28,31; 1Ts 2,1-2.17-18; 3,1-3a; Rm 11,1c; 15,19b.22-23; 16,1; 1Cor 5,9; 7,7-8; 16,1-9; 2Cor 2,1.9-13; 11,7-9.23-27,32-33; 12,2-4.14.21; 13,1.10; Gl 1,13-23; 2,1-14; 4,13; Fl 3,5-6; 4,15-16). Segundo estudos feitos, certamente sete cartas (Romanos, 1 e 2 Coríntios, Gálatas, Filipenses, 1Tessalonicenses e Filemon) sem dúvida foram escritas ou ditadas de viva voz pelo próprio Paulo, sendo consideradas escritos paulinos genuínos. Essas são consideradas autênticas e constituem um testemunho direto, e, por isto, têm um valor muito importante. As outras seis cartas: Efésios, Colossenses, 2 Tessalonicenses, 1 e 2 Timóteo e Tito são atribuídas a Paulo ou no pior dos casos, a profundos conhecedores do Apóstolo ${ }^{14}$. Ao lado das cartas colocase, como fonte secundária, os Atos dos Apóstolos, que segundo a tradição foi escrito por Lucas, o mesmo que escreveu o Terceiro Evangelho.

De acordo com Lc e At podemos traçar uma breve cronologia da vida do Apóstolo Paulo (At 7,58; 9,23-26; 11,27-30; 12,25; 13-18; 23,24; 24,1-7; 28,30; Rm 15,24.28.30-31; 1Cor 16,1-4; 2Cor 11,32-33; Gl 1, 18.21; 2,5.11-14; 4,13) ${ }^{15}$ que servirá para se ter uma noção concreta deste que é considerado um dos maiores marcos da evangelização e anunciador do Crucificado-Ressuscitado ${ }^{16}$ :

-6-8 d.C.: Nascimento de Paulo

•33-36 d.C.: Conversão ou chamado ${ }^{17}$ (At 9,1-19,25)?

\footnotetext{
${ }^{13}$ G. BARBAGLIO. La persona e l'opera di Paolo. In: A. SACCHI et al. ed. Lettere Paoline e altre Lettere, p. 53-60; A. SACCHI. La cronologia Paolina. In: A. SACCHI et al. ed. Lettere Paoline e altre Lettere, LCSB 6. Torino: Elledici, 1996, p. 61-68.

${ }^{14}$ J. SANCHEZ BOSCH. Escritos paulinos. IEB 7, Estalla (Navarra): Editorial Verbo Divino, 1998, p. 15.

${ }^{15}$ A. SACCHI. La cronologia Paolina. In: A. SACCHI et al. ed. Lettere Paoline e altre Lettere, p. 67.

${ }^{16}$ R. PENNA. I Ritratti originali di Gesù il Cristo: Inizi e sviluppi della cristologia neotestamentaria, I. Gli sviluppi, Studi sulla Bibbia e il suo Ambiente. Cinisello Balsamo: San Paolo Edizioni, 1996, 200133, p. 137: Termo usado por Romano Penna: "Il Crocifisso Risorto".

${ }^{17}$ R. PENNA. I Ritratti originali di Gesù il Cristo: Inizi e sviluppi della cristologia neotestamentaria, I, p. 101: "Ci si potrebbe chiedere a questo punto (e la cosa ha pure un risvolto cristologico) se l'esperienze vissuta da Paolo a Damasco possa essere definita con la tradizionale categoria 'conversione' o se invece sai più appropriata la definizione di 'chiamata'. Questa seconda sarebbe più pertinente, stando al giudizio di alcuni esegeti, dato che l'Apostolo per illustrare il proprio caso

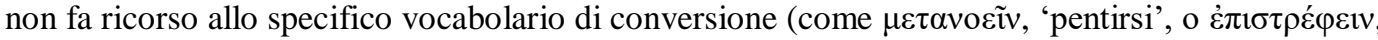
'rivolgersi, tornare') ma utiliza vocaboli di altro tipo (come $\kappa \alpha \lambda \varepsilon \tilde{v}$, 'chiamare', $\alpha \varphi \rho \rho i ́ \zeta \varepsilon 1$, 'mettere
} 
-37 d.C.: Primeira visita a Jerusalém e encontro com Pedro (At 9,26.30)

-45-49 d.C.: Primeira viagem missionária (At 13,1;14,28) ${ }^{18}$

- 49 d.C.: Assembleia de Jerusalém

-49-52 d.C.: Segunda viagem missionária e permanência em Corinto (At $15,36-18,17)^{19}$

-52-54 d.C.: Terceira viagem. Permanência de 2 anos e meio em Éfeso

-54-55 d.C.: Permanência de 3 meses em Corinto (inverno) e viagem a Jerusalém

-56-58 d.C.: Prisão em Cesareia

•58-59 d.C.: Viagem em direção a Roma (inverno), onde foi levado como prisioneiro.

• 59-61 d.C.: Prisão romana

- 67 d.C.: Morte em Roma

Com a precedente cronologia obtemos um certo conhecimento do trajeto percorrido durante a vida de Paulo. No entanto, fica ainda a pergunta quem é Paulo de Tarso que será conhecido depois como apóstolo dos pagãos $(\operatorname{Rm} 11,13)^{20}$ ?

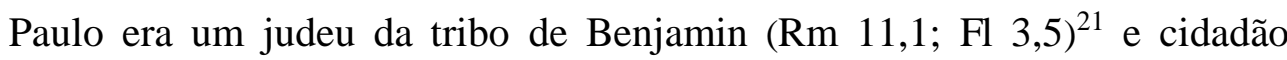
romano (At 16,37; 25,11-12; 26,32; 28,19)22, nascido em Tarso da Cilícia (At $21,39)^{23}$, contudo, crescido em Jerusalém (At 22,3). Formado na escola do rabino

a parte', scegliere, e $\dot{\alpha} \pi \circ \kappa \alpha \lambda v ́ \pi \tau \varepsilon ı$, 'rivelare') che insistono meno sul livello antropologico dell'evento e più su quello propriamente teológico; perciò il caso-Paolo viene accostato a quello degli antichi profeti come Isaia e Geremia, di cui appunto non si può dire che si siano convertiti ma solo che sono stati chiamati"; K. STENDAHL. Paolo tra ebrei e pagani. Picolla Collana Moderna, Serie Teologica 74. Torino: Claudiana Editrice, 1995, p. 59: "Ci troviamo di fronte a una chiamata alla missione, non a una conversione".

${ }^{18}$ L.C.A. ALEXANDER. Cronologia di Paolo. In: G.F. HAWTHORNE; R.P. MARTIN; D.G. REID. Dizionario di Paolo e delle sue Lettere. Cinisello Balsamo: San Paolo Edizioni, 2000, p. 414: "Primo viaggio missionario: Antiochia, Cipro, Panfilia, Psidia, Iconio, Listra, Derbe, Antiochia".

19 L.C.A. ALEXANDER. Cronologia di Paolo. In: G.F. HAWTHORNE; R.P. MARTIN; D.G. REID. Dizionario di Paolo e delle sue Lettere. p. 414: "Secondo viaggio missionario: Siria e Cilicia, Frigia, Galazia, Filippi, Tessalonica, Berea, Atene, Corinto".

20 J.D.G. DUNN. Lettera ai Romani. In: G.F. HAWTHORNE; R.P. MARTIN; D.G. REID. Dizionario di Paolo e delle sue Lettere, p. 1353.

${ }^{21}$ S. LÉGASSE. Paolo Apostolo: Biografia crítica. Roma: Città Nuova, 1994, p. 30-31.

22 J. MURPHY-O'CONNOR. Vita di Paolo. Introduzione allo Studio della Bibbia, Supplementi 13, Brescia: Editrice Paideia, 2003, p. 57.

${ }^{23}$ H. OBERMAYER et. al. Paolo. In: H. OBERMAYER; K. SPEIDEL; K. VOGT; et. al. ed. Piccolo Dizionario Biblico. Cinisello Balsamo: San Paolo Edizioni, 1997, p. 239: "La sua origine da Tarso (importante città portuale) consentì di apprendere la lingua parlata dovunque, di conoscere la cultura greca, la filosofia popolare e la religione, come pure l'ambiente dell'impero romano. Paolo pensava e parlava disinvoltamente greco ed era così aperto per un contato con il centro del mondo di allora, 
Gamaliel com as mais rígidas normas da Lei Paterna, cheio de zelo por Deus (At 22,3; Gl 1,13; Fl 3,6). Como fariseu viveu na mais rígida corrente farisaica preponderante da época (At 26,5). Ademais, podemos indicar duas realidades que caracterizam o nosso extraordinário autor antes de seu chamado ${ }^{24}$ :

- participação convicta e zelante na religiosidade judaica dos seus antepassados (2Cor 11,22; Gl 1,13-14; Fl 3,5-6).

- hostilidade não privada de violência externa no confronto com o neonascido movimento cristão (At 22,4; 1Cor 15,9; Fl 3,5-6; 26,10-11). E. Hänchen $^{25}$ diz que o autor sagrado nestes textos (At 9,1; 22,4; 26,10-11) fala de Paulo não somente como um simples perseguidor, mas quase como a perseguição em pessoa.

Mesmo com uma vida zelante na religiosidade judaica, na existência de Paulo verifica-se uma mudança decisiva quando na estrada de Damasco ${ }^{26}$ encontra o Senhor ressuscitado e assim o acolhe ${ }^{27}$ como realidade única da sua vida.

\footnotetext{
Roma, dove si parlava pure greco. Egli apprese la tecnica artigianale del fabbricatore di tende (tessitore o solo sarto delle tende o le due cose insieme?), che egli praticava ancora da apostolo (At 18,$3 ; 1$ Tes 2,9). Dal punto di vista medico, egli era disturbato da un indebolimento o malattia non meglio identificabile (At 21,39,13ss.; 2Cor 12,7ss., Gal 4,13ss.)".

${ }^{24}$ G. BARBAGLIO. La persona e l'opera di Paolo. In: A. SACCHI et al. ed. Lettere Paoline e altre Lettere, p. 54

${ }^{25}$ HÄNCHEN apud G. BARBAGLIO. La persona e l'opera di Paolo. In: A. SACCHI et al. ed. Lettere Paoline e altre Lettere, p. 54

${ }^{26}$ R. PENNA. I Ritratti originali di Gesù il Cristo: Inizi e sviluppi della cristologia neotestamentaria, I, p. 96-97: "Certo Paolo aveva sentito parlare di Gesù anche prima di Damasco. Lo possiamo dedurre non soltanto dal fatto che egli condusse una fiera persecuzione nei confronti della comunità dei suoi discepoli (Gal 1,13-14; At 8,3), ma anche da quei passi delle lettere in cui si può intravedere un riferimento autobiografico sufficientemente chiaro alle sue concezioni su Gesù anteriori all'evento damasceno. Per esempio, se in 1Cor 1,23 egli dichiara che Gesù crocifisso è 'scandalo per i Giudei', possiamo ben ritenere che tale in passato egli fosse considerato anche da lui, che era stato un giudeo quanto mai rigoroso. Analogamente, se in Gal 3,13 egli cita il passo Deut 21,23 secondo cui 'è maledetto chiunque sia appeso al legno', è evidente che il testo biblico deve essergli servito già prima come motivo di rifiuto e di condanna del crocifisso Gesù"; M. HENGEL. Il Paolo prescristiano. SB 100. Brescia: Paideia Editrice, 1992, p. 153-192.

${ }^{27}$ R. PENNA. I Ritratti originali di Gesù il Cristo: Inizi e sviluppi della cristologia neotestamentaria, I, p. 98.103-104: "La Cristologia di Paolo ha dunque un punto di partenza non dottrinale, ma vissuto; E comunque chiaro dal caso di Paolo che propriamente non ci si converte né ad una dottrina né ad una istituzione ma ad una persona, così da stabilire con essa una relazione viva e totalizzante. Nient'altro che questo significa l'Apostolo quando scrive: 'Non sono più io che vivo, ma Cristo vive in me' $($ Gal 2,20) o quando dice: 'Per me vivere è Cristo' (Flp 1,21); cioè: la persona di Cristo è ormai la vera ragion d'essere e costituisce tutto il senso della vita di Paolo dopo l'incontro con Luil'.
} 


\subsubsection{Destinatário}

Do que é possível coletar de informações retirada da própria introdução à Carta, não resta dúvidas que Paulo envia seu testamento "a todos aqueles que chama de amados de Deus e chamados à Santidade" $(\mathrm{Rm} 1,7)^{28}$, isto é, à comunidade cristã em Roma. Ademais, a Igreja de Roma era composta por cristãos vindos tanto do judaísmo como do paganismo, provenientes de todas as partes do Império ${ }^{29}$.

\subsubsection{Ocasião da composição da carta}

Para tentarmos determinar com maior precisão qual foi o motivo pelo qual Paulo escreveu sua carta à comunidade de Roma, nos apoiaremos na posição de Sanchez Bosch e Romano Penna ${ }^{30}$, que tratam da temática em suas obras.

Segundo Sanchez Bosch, o apóstolo tinha consciência de ter concluído uma grande obra, mas tinha dentro de si, o desejo de evangelizar ainda os confins da terra. Com isto Paulo pensa que é o momento de escrever uma espécie de testamento, uma opus maius, onde pudesse resumir o período mais importante de sua vida. No mais, o apóstolo dos gentios dirige esta carta a Roma pelo fato que ele tinha sempre diante de si o futuro, onde a fé dos romanos, que já era anunciada por todo o mundo ( $\mathrm{Rm} 1,8)$, o permitiria, do ponto de vista prático, preparar a viagem ${ }^{31}$ para seu novo ponto de evangelização, a Espanha ${ }^{32}$.

Já Romano Penna ${ }^{33}$, para determinar o motivo pelo qual Paulo escreve sua carta à comunidade de Roma, utiliza um dado importante citado por Baur ${ }^{34}$, da Universidade de Tubinga, mostrando a situação daquela comunidade:

\footnotetext{
${ }^{28}$ U. VANNI. Lettere ai Galati e ai Romani. Torino: Claudiana, 1989, 72, p. 91.

${ }^{29} \mathrm{O}$ evento de Pentecostes relata a presença de Romanos (At 2,10). Esta ideia confirma o fato que a comunidade cristã presente no local não foi fundada por Paulo.

${ }^{30}$ J. SANCHEZ BOSCH. Escritos paulinos, p. 286; R. PENNA. Lettera ai Romani: Rm 1-5 (I), p. 43-50.

${ }^{31}$ Dois fatores dão a Roma uma certa importância: a) Roma é uma capital, e as capitais são grandes pontos de referimento para a evangelização de Paulo; b) Roma é um grande centro de informações geográficas, demográficas e de potencial econômico importante para a ajuda às comunidades.

32 J.D.G. DUNN. Lettera ai Romani. In: G.F. HAWTHORNE; R.P. MARTIN; D.G. REID. Dizionario di Paolo e delle sue Lettere, p. 1356.

${ }^{33}$ R. PENNA. Lettera ai Romani: Rm 1-5 (I), p. 15-32.

${ }^{34}$ BAUR apud R. PENNA. Lettera ai Romani: Rm 1-5 (I), p. 44; Com relação a esta posição de Baur, hoje muitos autores se pronunciam neste mesmo sentido como por exemplo: J.W. DRANE. Why did Paul write Romans? In: D.A. HANGER; M.J. HARRIUS ed. Exter: Pauline Studies, 1980, p. 208-227; J.A. CRAFTON. Paul's Rhetorical Vision and the Purpose of Romans. Toward a New Understanding. NT 32. Evanston, Il: Biblical studies,1990, p. 317-339.
} 
Baur servia-se de uma visão da história construída pela escola de Tubinga, que via o desenvolvimento protocristão como uma tensão dialética entre o judaísmo e o paulinismo (com a posição mediana do petrinismo). De modo concreto ele afirmava que Paulo com sua carta direcionava-se à Igreja Romana para estimular os seus membros judeus-cristãos a abrirem-se ao Universalismo do Evangelho contra toda forma de particularismo judaico ou judaista.

\subsubsection{Data e lugar da composição}

Normalmente a posição aceita pelos estudiosos é que em um inverno tranquilo, provavelmente ao fim da terceira viagem entre os anos 55 e 58 d.C. ${ }^{35}$, na cidade de Corinto $^{36}$, com esperança de futuras evangelizações "até o extremo da terra" (Rm 15,24.28) e com certo temor de um possível fim trágico em Jerusalém, Paulo dedicou seu testamento espiritual à comunidade de Roma ${ }^{37}$. Provavelmente Paulo está no fim da terceira viagem missionária ${ }^{38}$, em Corinto.

\footnotetext{
${ }^{35}$ U. VANNI. Lettere ai Galati e ai Romani, p. 72: "Segundo Vanni, existe entre os autores opiniões diversificadas sobre a data de composição da Carta aos Romanos. Sabemos que entre os anos de 5254 ele tinha iniciado sua terceira viagem missionária, um terminus post quem. No ano 59 com a chegada de P. Festo a Cesareia, constitui um terminus ante quem. Entre esses dois extremos oscilam a verificação dos particulares períodos descritos pelos Atos dos Apóstolos e deduzidos pelas Cartas, e em proporção oscila também a data da Carta aos Romanos. Por exemplo S. ZEDDA. Prima lettura di S. Paolo. Brescia: Paideia Editrice, 1963, 19735 p. 303, fala de inverno 57-58; F. J. LEENHARDT. L'Epître de St. Paul aux Romains. Neuchâtel-Paris: Desclée de Brouwer, 1962, p. 7 e J. M. LAGRANGE. L'Epître aux Romains. Paris: Etudes Bibliques 1916, p. XVIII-XX, falam da primavera de $57^{\prime \prime}$.

36 J.D.G. DUNN. Lettera ai Romani. In: G.F. HAWTHORNE; R.P. MARTIN; D.G. REID. Dizionario di Paolo e delle sue Lettere, p. 1354: "La relazione tra Rom 15,25 e At 20 rivela anche quale sia il luogo di origine della lettera, poiché At 20,3 parla di tre mesi trascorsi in Grecia prima di iniziare il viaggio finale verso Gerusalemme. Questo ci fa pensare a Corinto, che è la residenza principale di Paolo in Grecia, e concorda con quanto è detto in Rom 16: Febe era di Cencre, uno dei porti di Corinto (Rom 16,1-2), e Gaio ed Erasto (Rom 16,23) abitavano probabilmente a Corinto (1Cor 1,14; NewDocs 4.160-161). Ma la cosa più importante è che un soggiorno di tre mesi in una sola località può aver lasciato a Paolo tutto il tempo necessario per progettare, compore e dettare quella che è la sua lettera meglio elaborata e formulata".

${ }^{37}$ J. SANCHEZ BOSCH. Escritos paulinos, p. 287.

${ }^{38}$ J.D.G. DUNN. Lettera ai Romani. In: G.F. HAWTHORNE; R.P. MARTIN; D.G. REID Dizionario di Paolo e delle sue Lettere, p.1353: "Per quanto riguarda la data, il punto più significativo è che Paolo ha scritto la sua Lettera nel momento in cui riteneva d'aver portato a termine la fase più importante del suo lavoro, ossia l'evangelizzazione del settore nordoccidentale del Mediterraneo (Rom 15,19.23). La notizia che egli stava partendo per una visita a Gerusalemme (Rom 15,25$)$ concorda con la descrizione più ampia di una visita finale a Gerusalemme che si trova negli Atti, alla conclusione (che si sarebbe rivelata definitiva) della attività da lui svolta in Asi Minore e Grecia (At 20). Questo induce chiaramente a fissare la data di composizione verso la metà degli anni Cinquanta (55-57 d.C.)".
} 


\subsubsection{Significado da Carta aos Romanos}

Romano Penna, na premissa do seu livro sobre a Carta aos Romanos, diz que a Carta é o primeiro escrito neo-testamentário no qual temos um comentário completo desde 243 d.C. herdado do grande alexandrino Orígenes. Desta data até os dias de hoje os trabalhos sobre esta carta têm-se multiplicado de forma exponencial, confirmando a enorme importância ${ }^{39}$ do escrito paulino para a fé, para a teologia, para a espiritualidade e para o formulado pensamento da civilização ocidental $^{40}$.

Entre os escritos Neo-testamentarios a Carta aos Romanos ${ }^{41}$ é provida de um grande valor para o Cristianismo, ela é também aquela na qual encontramos menos controvérsia no que diz respeito ao autor, ao conteúdo, ao tempo e aos destinatários que são grandes problemas para se resolver e para se precisar nos outros escritos neo-testamentários ${ }^{42}$.

$\mathrm{Na}$ antiguidade cristã podemos observar os exemplos claros de Marcião que extrai os motivos para sua concepção herética de separação do cristianismo, da herança antiga testamentária e judaica. Já Agostinho, com a leitura desta Carta, foi impulsionado para a conversão e inspirado decisivamente na polêmica antipelagiana.

Também a Reforma Protestante ${ }^{43}$ utiliza a Carta aos Romanos como texto sagrado de suas inspirações. O próprio Lutero afirma: "Foi como se escancarasse

39 J.D.G. DUNN. Lettera ai Romani. In: G.F. HAWTHORNE; R.P. MARTIN; D.G. REID. Dizionario di Paolo e delle sue Lettere, p. 1353: "La più importante in quanto essa rappresenta la prima elaborazione teologica giunta sino a noi, dovuta a un teologo cristiano, la quale ha avuto un influsso enorme sulla formulazione della teologia cristiana di tutti i tempi, e anzi può essere considerata l'opera teologica cristiana più importante che mai sia stata scritta".

${ }^{40}$ R. PENNA. Lettera ai Romani: Rm 1-5 (I), p. 19.

41 J.A. FITZMYER. La Lettera ai Romani: Commentario critico-teologico, p. 1087: "Rom ha influenzato la successiva teologia cristiana più di qualsiasi altro libro del NT Raramente un ambito della riflessione teologica non ha risentito del suo insegnamento. La sua influenza è evidente anche in altri scritti del NT (1Pe, Heb e Tg) ed opere subapostoliche (Clemente, Ignazio, Policarpo, Giustino). Abbondano i commentari patristici scolastici su Rom; a cominciare da Origene, gli interpreti principali sono Crisostomo, Teodoreto, Giovanni Damasceno, Ecumenio, Teofilatto, Ambrosiaster, Pelagio, Ugo di S. Vittore, Abelardo e Tommaso d'Aquino. Immensa è la parte che Rom ha avutto nel dibattito della Riforma. Famosi commentari sono stati scritti da Martin Lutero, F. Melantone e G. Calvino. Anche il pensiero religioso moderno è stato molto influenzato dai commentari teologici di K. BARTH, Epistola ai Romani; A. NYGREN, Commentary on Romans; H. ASMUSSEN, Der Römerbrief e E. BRUNNER, Der Römerbrief. Il contributo che Rom ha dato al pensiero cristiano occidentale è inestimabile".

${ }^{42}$ J.D.G. DUNN. Lettera ai Romani. In: G.F. HAWTHORNE; R.P. MARTIN; D.G. REID Dizionario di Paolo e delle sue Lettere, p. 1353.

${ }^{43}$ G. BARBAGLIO. Lettere di Paolo, p. 171: "Di fatto, il cammino del protestantismo è stato segnato indelebilmente dai commenti di Lutero, Calvino e Melantone". 
para mim a porta do paraíso"44. Já nos tempos modernos podemos recordar a obra de K. Barth: a sua "tradução radical"45 representou, em 1919, uma nova transformação na teologia protestante alemã, colocando um ponto final ao domínio liberal e inaugurando o dialético. Enfim, vemos a Carta de Romanos no renovado diálogo ecumênico dos nossos dias, onde esta carta não é mais vista tanto como texto que divide, como no séc. XVI, mas usada como texto capaz de unir os que acreditam em Cristo.

Temos como um dos sinais dos tempos, o fato de que em 1965 a tradução ecumênica da Bíblia de língua francesa (TOB) iniciou seus trabalhos com a Carta aos Romanos. Por fim, Barbaglio, fazendo suas as palavras do pastor protestante Bögner, afirma: "o texto das nossas divisões devia transformar-se no texto do nosso encontro" $"$.

\footnotetext{
${ }^{44}$ LUTERO apud G. BARBAGLIO. Lettere di Paolo, p. 171.

${ }^{45}$ BARTH apud G. BARBAGLIO. Lettere di Paolo, p. 171.

${ }^{46}$ BÖGNER apud G. BARBAGLIO. Le Lettere ai Romani, p. 171.
} 


\section{Disposição Retórica, Texto e Crítica Textual}

Com Aristóteles a arte da Retórica $\mathrm{Grega}^{47}$ de seus predecessores, como Gorgia, Protagóras e Platão, é retomada e ampliada nos seus estudos. Sua obra foi a fonte de inumeráveis manuais de Retórica Grega e Latina durante o I séc. d.C. ${ }^{48}$ Segundo Aristóteles, a arte de persuadir depende de três fatores: ethos "o caráter moral de quem fala", pathos "as emoções suscitadas nos ouvintes" e logos "os argumentos lógicos do discurso" $" 49$.

Já na tradição clássica podemos encontrar três tipos de retóricas: a forense, a deliberativa e a epidítica. A forense defende ou acusa alguém pelas ações passadas, a deliberativa exorta ou dissuade com relação às ações futuras e a epidítica afirma valores comuns através de elogios ou críticas para influenciar numa avaliação presente $^{50}$.

\subsection{Disposição retórica da Carta aos Romanos}

Segundo a Hermenêutica da Retórica Clássica e graças à Manualística Latina que teve o mérito na repartição retórica, foram-se determinando as partes de um discurso ou escrito retórico, Assim Cornificio define as cinco partes da partitio:

É necessário que no discurso exista a invenção, a disposição, a elocução, a memória e a pronúncia. A invenção é o lugar das coisas verdadeiras que tornam a causa provável. A disposição é a ordem e distribuição das coisas, ou seja, de que modo devem ser colocadas as coisas. A elocução quer dizer: a modalidade da expressão pela invenção das palavras e das frases. A memória diz respeito à fixação no centro das coisas, das palavras e da disposição. A pronúncia se refere à moderação, com dignidade na voz, no rosto e nos gestos ${ }^{51}$.

\footnotetext{
${ }^{47}$ Segunda métade do IV séc. a.C.

${ }^{48}$ G.W. HANSEN. Critica Retorica. In: G.F. HAWTHORNE; R.P. MARTIN; D.G. REID. Dizionario di Paolo e delle sue Lettere. Cinisello Balsamo: San Paolo Edizioni, 2000, p. 384.

${ }^{49}$ G.W. HANSEN. Critica Retorica. In: G.F. HAWTHORNE; R.P. MARTIN; D.G. REID. Dizionario di Paolo e delle sue Lettere, p. 384.

${ }^{50}$ G.W. HANSEN. Critica Retorica. In: G.F. HAWTHORNE; R.P. MARTIN; D.G. REID. Dizionario di Paolo e delle sue Lettere, p. 385: "W. Wuellner mostra come la discussione sulla legge in Romani possa essere chiarita osservando lo scopo epidittico (non forense, come in Galati) della lettera".

${ }^{51}$ CORNIFICIO apud A. PITTA. Disposizione e messaggio della Lettera ai galati. Analisi retoricoletteraria. Analecta Biblica. Roma: Editore Pontificia Universitá Gregoriana, 1992, p. 54.
} 
No tempo de Paulo o mundo era profundamente fascinado pela oratória pública passada por homens que, através da arte do falar de modo enfático, procuravam "persuadir" seu(s) auditor(es) a uma suposta aceitação ou adesão à mensagem proferida $^{52}$. No cristianismo essa arte da pregação era como um termômetro para determinar a capacidade do orador. No entanto, com base na 1Cor 2,1-5, Winter afirma que o discurso de Paulo era uma demonstração da ação do Espírito $^{53}$ :

No seu discurso e na sua pregação Paulo não usava a retórica persuasiva. Pois, afirmava que era uma demonstração do Espírito e da sua potência. A renúncia, por parte de Paulo, do uso da retórica na pregação, que no seu tempo era muito admirada, foi um passo radical e arriscado. Mas, sua renúncia foi motivada pelo desejo que a fé dos seus fiéis convertidos não se fundasse na sabedoria humana, mas sobre a potência de Deus.

A seguir, para termos uma visão mais apurada da mensagem Paulina e evitarmos uma leitura diretamente teológica ${ }^{54}$ que deturpe a real intenção da mensagem do apóstolo, apresentaremos, na visão de Aletti e Pitta, a dispositio e estrutura da Carta aos Romanos:
A) Dispositio
1,16-17: Propositio principal
1,18-11,36: Probatio - em três partes diversas:
$\bullet 1,18-4,25$ :
1,18: subpropositio
1,19-32: narratio
2,1-3,18: probatio
3,19-20: peroratio
3,21-22a: subpropositio

\footnotetext{
${ }^{52}$ Um grande exemplo são os chamados sofistas que através do uso da oratória convenciam os ouvintes para acolherem as suas ideias. Podemos ver também muito claro ainda hoje, esta arte da oratória no exercício da política e da advocacia.

${ }^{53}$ B.W. WINTER. Retorica. In: G.F. HAWTHORNE; R.P. MARTIN; D.G. REID. Dizionario di Paolo e delle sue Lettere Cinisello Balsamo: San Paolo Edizioni, 2000, p. 1327; 1 Cor 2,1-5: "Eu mesmo, quando fui ter convosco, irmãos, não me apresentei com o prestígio da palavra ou da sabedoria para vos anunciar o mistério de Deus. Pois não quis saber outra coisa entre vós a não ser Jesus Cristo, e Jesus Cristo crucificado. Estive entre vós cheio de fraqueza, receio e tremor; minha palavra e minha pregação nada tinham da persuasiva linguagem da sabedoria, mas eram uma demonstração de Espírito e poder, a fim de que a vossa fé não se baseie sobre a sabedoria dos homens, mas sosbre o poder de Deus".

54 J.N. ALETTI. Romanos: Comentario Bíblico Internacional. Estella (Navarra): W.R. Farmer, 1999, p. 14-16; A. PITTA. Lettera ai Romani: Nuova versione, introduzione e commento, LBNT 6. Milano: San Paolo, 2001, p. 31-33.
} 
3,22b-4,25: probativo

- 5,1 - 8,39:

5,1-11: exordium

5,12-21: narratio

5,20-21: subpropositio

6,1-8,30: probativo

(completa em $6.1,15 ; 7.7 ; 8.1,2$ )

8,31-39: peroratio

$\bullet 9,1$ - 11,36:

9,1-5: exordium seguido de três subdivisões

$\mathrm{A}=9,6-29$ :

9,6a: subpropositio;

9,6b-29: probatio

$\mathrm{B}=9,30-10,21$ :

9,30-10,3: exordium

10,4: subpropopositio

10,5-21: probatio

$\mathrm{A}^{\prime}=11,1-32$ :

11,1: subpropositio;

11,2-32: probatio

11,33-36: peroratio

B) Estrutura

Introdução (Rm 1,1-17)

O pré-escrito $(1,1-7)$

Exórdio (1,18-15)

A tese geral $(1,16-17)$

O corpo espitolar $(\mathbf{R m} 1,18-15,13)$

A. SESSÃO DEMONSTRATIVA $(1,18-11,36)$

A revelação da ira e da justiça divina ( $\mathrm{Rm} 1,18$ - 4,25)

A revelação da ira divina $(\mathrm{Rm} 1,18$ - 3,20)

A narração $(1,18-32)$

As provas $(2,1-3,18)$

A imparcialidade divina (2,1-11)

Os gentios, os judeus e a lei $(2,12-16)$

A paródia $(2,17-24)$

Os judeus, os gentios e a circuncisão (2,25-29)

A vantagem do judeu $(3,1-8)$

A universalidade da culpa (3,9-18)

A defesa da acusação $(3,19-20)$

A manifestação da justiça divina $(3,21-4,25)$ 
A justificação por meio da Fé em Cristo (3,21-26)

A exclusão do orgulho (3,27-31)

O exemplo de Abraão (4,1-25)

A fé de Abraão (4,1-8)

A garantia (4,9-12)

A promessa e a herança $(4,13-22)$

A defesa (4,23-25)

O paradoxo do orgulho cristão $(5,1-8,39)$

Da justificação até a paz (5,1-11)

O confronto entre Jesus e Adão (5,12-21)

A incompatibilidade da graça e o pecado $(6,1-14)$

O Senhorio da Graça $(6,15-23)$

O pertencer a Cristo e não à lei (7,1-6)

A tragédia do eu e da lei $(7,7-25)$

A tragédia da lei $(7,7-13)$

A tragédia do eu $(7,14-20)$

O epílogo trágico $(7,21-25)$

A Lei do Espírito (8,1-13)

A Filiação no Espírito $(8,14-17)$

Sofrimento e glória (8,18-30)

O Amor de Deus e de Cristo (8,31-39)

A fidelidade da palavra de Deus $(9,1-11,36)$

Uma grande tristeza $(9,1-5)$

Nem todo Israel é fiel $(9,6-29)$

Israel e a eleição $(9,6-13)$

A Justiça e a Misericórdia divina $(9,14-18)$

Como um oleiro $(9,19-23)$

A chamada dos judeus e dos gentios $(9,24-29)$

Cristo o fim da lei $(9,30$ - 10,21)

Israel e a Justiça divina $(9,30-10,4)$

A justiça da fé (10,5-13)

A Palavra de Cristo (10,14-17)

Israel é indesculpável (10,18-21)

Deus não rejeitou o seu povo (11,1-36)

$O$ resto $(11,1-10)$

Queda e inveja (11,11-16)

Oliveira brava e seiva da oliveira $(11,17-24)$

O mistério $(11,25-36)$

B. A PARACLESE $(12,1-15,13)$

O culto da razão $(12,1-13,14)$

O teste $(12,1-2)$

Moderação na comunidade (12,3-8)

O amor como ideal do belo e do bom (12,9-21)

Submissão à autoridade civil $(13,1-7)$

Amor recíproco (13,8-10)

A espera do dia (13,11-14) 
O recíproco acolhimento entre os fortes e os fracos $(14,1-15,13)$

O Acolhimento dos fracos (14,1-12)

Contra o escândalo do irmão (14,13-23)

Cristo, modelo para os fortes (15,1-6)

A defesa sobre o recíproco acolhimento (15,7-13)

\section{O pós-escrito epistolar (Rom 15,14 - 16,27)}

O orgulho da evangelização $(15,14-21)$

Os próximos projetos de viagem $(15,22-33)$

Recomendações e saudações finais (16,1-16)

Admoestação e bênção final (16,17-20)

Saudações da comunidade de partida $(16,21-23)$

Doxologia final $(16,25-27)$

\subsection{Texto e crítica textual}

O texto editado pela $28^{a}$ edição de Nestle-Aland que utilizaremos sobre a Epístola aos Romanos contém 16 capítulos e "na opinião da maior parte dos estudiosos este não levantou dúvidas quanto à sua autenticidade" ${ }^{" 55}$. Conforme a estrutura proposta por J.N. Aletti ${ }^{56}$ nossa perícope encontra-se no centro da Carta dentro da subdivisão que vai de $\operatorname{Rm}$ 5,1- 8,39 sob a denominação de "o paradoxo do orgulho cristão. O capítulo 8 tem importância fundamental na Carta, por se tratar de temática imprescindível para o apóstolo Paulo que, durante seu ministério e em outras epístolas, externa diversas vezes a ação do Espírito Santo. James Dunn diz que o capítulo 8 é "inquestionavelmente o ponto alto da teologia do Espírito de Paulo"57.

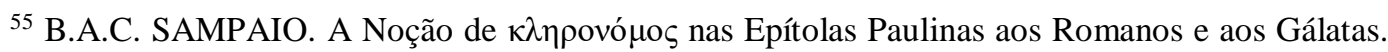
Thesis as Doctoratum in Theologia totaliter edita. Roma: Pontificia Universitas Sanctae Crucis, 2000, p. 110.

${ }^{56}$ J.N. ALETTI. Romanos: Comentario Bíblico Internacional, p. 1416.

${ }^{57}$ J.D.G. DUNN. A teologia do apóstolo Paulo. São Paulo, Paulus, 2003, p. 255.
} 


\begin{tabular}{|c|c|c|}
\hline Texto original & Vers. & Tradução $^{58}$ \\
\hline 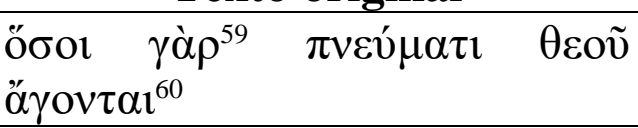 & $14 \mathrm{a}$ & $\begin{array}{l}\text { De fato, todos aqueles que são } \\
\text { conduzidos pelo Espírito de Deus }\end{array}$ \\
\hline oṽ̃ & $14 \mathrm{~b}$ & esses são filhos de Deus. \\
\hline 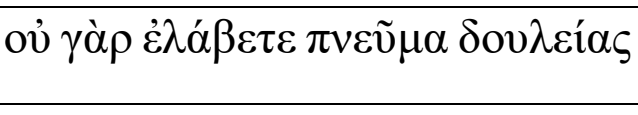 & $15 \mathrm{a}$ & $\begin{array}{l}\text { De fato, vós não recebestes um } \\
\text { espírito de escravidão, }\end{array}$ \\
\hline 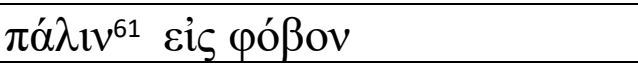 & $15 b$ & novamente para o medo \\
\hline 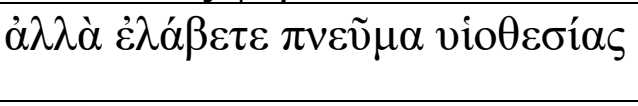 & $15 \mathrm{c}$ & $\begin{array}{l}\text { mas vós recebestes um } \\
\text { Espírito de Filiação, }\end{array}$ \\
\hline$\dot{\varepsilon} \nu \tilde{\hat{\omega}} \kappa \rho \alpha ́ \zeta o \mu \varepsilon v$. & $15 \mathrm{~d}$ & no qual gritamos: \\
\hline$A \beta \beta \alpha^{\prime}$ ó $\pi \alpha \tau \eta ́ p$ & $15 \mathrm{e}$ & Abba, Pai. \\
\hline 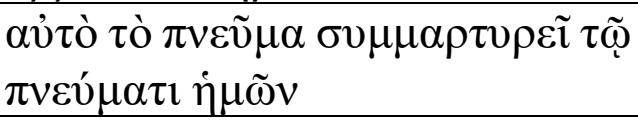 & $16 \mathrm{a}$ & $\begin{array}{l}\text { Ele, o Espírito, testemunha } \\
\text { junto ao nosso espírito }\end{array}$ \\
\hline 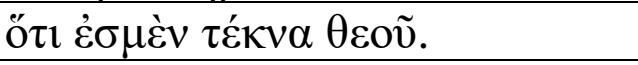 & $16 \mathrm{~b}$ & que somos filhos de Deus. \\
\hline$\varepsilon \grave{l} \delta \dot{\varepsilon} \tau \varepsilon ́ \kappa v \alpha, \kappa \alpha \grave{~} \kappa \lambda \eta \rho o v o ́ \mu o 1 \cdot$ & $17 \mathrm{a}$ & E se filhos, também herdeiros, \\
\hline 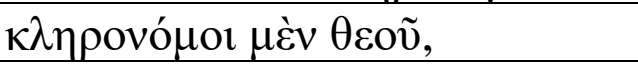 & $17 \mathrm{~b}$ & herdeiros certamente de Deus, \\
\hline 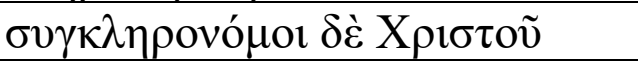 & $17 \mathrm{c}$ & isto é, co-herdeiros de Cristo \\
\hline 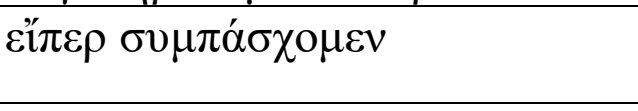 & $17 \mathrm{~d}$ & $\begin{array}{l}\begin{array}{l}\text { porque juntos } \\
\text { sofremos }\end{array} \\
\end{array}$ \\
\hline 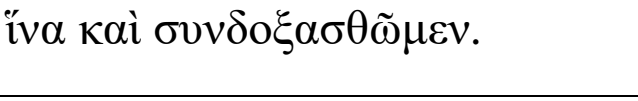 & $17 \mathrm{e}$ & $\begin{array}{l}\text { para também juntos com ele } \\
\text { sejamos glorificados. }\end{array}$ \\
\hline
\end{tabular}

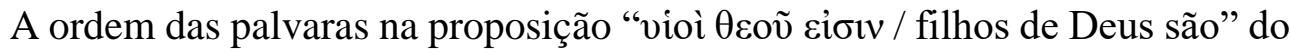
versículo 14 é alterada em alguns testemunhos. Na primeira variante os testemunhos do Vaticanus (B-03, séc. IV), Augiensis (F-010, séc. IX), Boernerianus (G-012, séc. IX), códice Monza (m-86, séc. X), Vulgata edição Stuttgartiensis ( $\left.\mathrm{vg}^{\mathrm{st}}, 1983\right)$, Orígenes (séc. III) e Pelágio (séc. V) alteram a ordem para "vioì દīoıv $\theta \varepsilon$ ov / filhos são de Deus".

\footnotetext{
${ }^{58}$ Nossa tradução seguirá as orientações propostas pela $\operatorname{Prof}^{a} \operatorname{Dr}^{a}$. Maria de Lourdes na seguinte obra: M.L.C. LIMA. Exegese Bíblica: teoria e prática. São Paulo: Paulinas, 2014, p. 79.

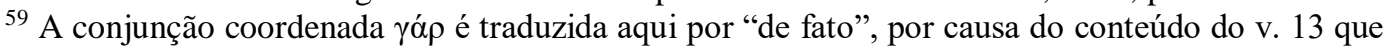
é apoiado pela afirmativa que segue intensificando a importância do Espírito na filiação como garantia antecipada da salvação futura.

${ }^{60}$ No português não tem muito diferença entre "conduzir" e "guiar", pois são sinônimos. Entretanto no grego, a voz média que representa o verbo ö $\gamma \omega$ declinado e intransitivo na perícope, por força do contexto, direciona o sentido para uma ação em conjunto e não totalmente extática, onde o indivíduo se deixa conduzir assumindo também o protagonismo interior em permitir a ação do Espírito. Essa

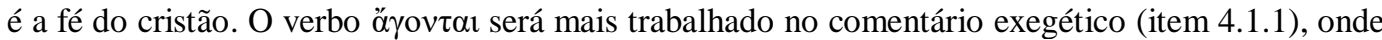
adotamos a posição de U. WILCKENS. La Carta a los Romanos 6-16 (II). BEB 61, 62. Salamanca: Ediciones Sigueme, 1992, p. 169.

${ }^{61} \mathrm{O}$ advérbio de modo " $\pi \alpha \dot{\lambda} \lambda \mathrm{v}$ / novamente" sustenta a ideia do não retorno ao status quo (da condição de escravos), no qual os fiéis haviam superado pela força do Espírito, e que pela inconstância cristã movida pelo medo, indicado com o acusativo masculino singular póßov, encontravam-se necessitados de uma nova motivação. Com isto, o apóstolo Paulo retoma a ideia do recebimento do Espírito de Filiação em contrapartida ao espírito de escravidão que encarcerava a população.
} 
Na segunda variação composta pelos manuscritos de comentário (K-018, séc.

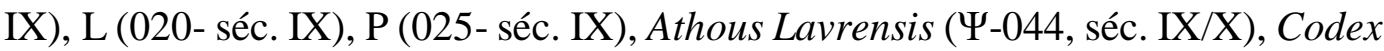
Colbertinus (33 - séc. IX), 104 (ano 1087), 1175 (séc. IX), 1241 (séc. XII), 1505 (séc. XII), 1881 (séc. XIV). 2464 (séc. IX), M (texto Majoritário Bizantino), Vulgata, Edição Clementina ( $\operatorname{vg}^{\mathrm{cl}}$ - 1592), Irenaeus e tradução latina (Ir ${ }^{\text {lat }}$ ano 395) alteram o texto para "cỉøıv viò̀ $\theta \varepsilon$ võ / são filhos de Deus".

Por sua vez, temos um grande grupo de testemunhos, dentre esses, 3 dos mais antigos e importante, que apoiam o texto editado, a saber: Codex Sinaiticus ( $\aleph-01$, 土 380), Codex Alexandrinus (A-02, séc. V), Codex Ephraemi Syri Rescriptus (C04, séc. séc. V), Codex Bezae Cantabrigensis (D-06, séc. V), 81 (ano 1044), 630 (séc. XII/XIII), 1506 (ano 1320), 1739 (séc. X), o Códice latino (ar-61, séc. IX), o Códice latino (b-89, séc. VIII/IX), Ambrosiaster (366-384) e Speculum/OsAugustine (séc. V).

Após realizada a análise, concluímos que as variantes não mudam a substância do texto pois, o mesmo mantém seu sentido original. É possível que as variações tenham sido alteradas por questões de estilo, erros de cópia ou ditado, ou por própria influência do contexto anterior à perícope estudada com o intuito de "harmonizar com o genitivo $\theta \varepsilon$ ṽ que conclui a maioria das frases $(1,1 ; 2,3.5 .29$; $3,3.23 ; 5,2)^{\prime 62}$ e facilita a leitura. Assim sendo, o texto editado é o mais apropriado e o qual optamos.

Com relação o versículo 16, o aparato crítico indica a inclusão da conjunção

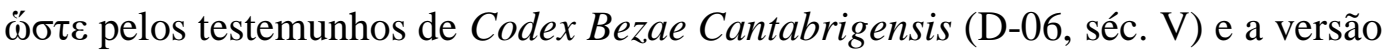
Siríaca Peshita (séc. IV/V). Tal acréscimo de uma conjunção subordinada pode ter sido pela necessidade de conectar os versículos, facilitando a leitura corrente entre eles. Entretanto, os testemunhos são unícos no caso em tela, demonstrando assim, que a maioria aprova o texto editado, não vendo imprescindibilidade da conjunção para facilitar a leitura. Portanto, a lectio difficilior probabilior ${ }^{63}$ prevalece como opção provável.

62 F.A. VASCONCELOS. Abba ho Patēr e Syn-Construtos: Formas de Antitéticas à Idolatria/Sincretismo em Rm 8,14-17. Doutorado (Teologia Bíblica). Rio de Janeiro: Pontíficia Universidade Católica do Rio de Janeiro, p. 113.

${ }^{63}$ W. GONZAGA. A Sagrada Escritura, a Alma da Sagrada Teologia. In: I. MAZZAROLO; L.A. FERNANDES; M.L.C. LIMA. Exegese, Teologia e Pastoral: relações, tensões e desafios. Santo André: PUC-Rio Academia Cristã, 2015, p. 221. 
Por fim, o Papiro de Chester Beatty ( $\mathfrak{P}^{46}$, antes da metade do séc. III), o manuscrito da Vulgata ( $\mathrm{vg}^{\mathrm{ms}}$, séc. IV/V) e os manuscritos da versão Copta, do dialeto Sahídico ou Boháirico ( $\mathrm{sa}^{\mathrm{ms}}$, a partir do terceiro século), omitem a conjunção кaí que tem sentido reforçativo ou aditivo, e que intensifica a situação daqueles que com Cristo sofrem para que com Ele sejam glorificados. Os testemunhos maiores que foram referidos na leitura de todo o aparato crítico da perícope, não se pronunciam sobre o fato, levando a crer que a omissão manifestada pelos testemunhos acima, não surtem efeitos modificativos no sentido do texto. Logo, concordamos com o princípio de que a lectio difficilior probabilior ${ }^{64}$ de fato é a mais provável aqui. Portanto, optamos pelo texto editado da $28^{a}$ edição de NestleAland.

\subsection{Disposição Retórica de Rm 8,14-17 no contexto imediato de Rm 8}

Neste subtópico iremos tabelar a perícope da Carta aos Romanos com o intuito de estabelecer uma provável estrutura que nos conceda, no trabalho exegético da leitura particularizada, obter uma melhor compreensão da mensagem que melhor representa o texto estudado em tela:

\begin{tabular}{|c|c|c|c|c|}
\hline \multirow[t]{2}{*}{ PARTE I } & \multirow{2}{*}{$\begin{array}{l}\text { Segmento } \\
1\end{array}$} & $14 \mathrm{a} \alpha$ & $\mathrm{A}$ & 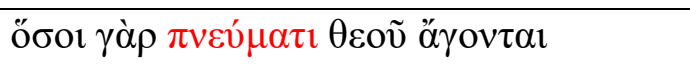 \\
\hline & & $14 \mathrm{~b} \beta$ & $\mathrm{B}$ & 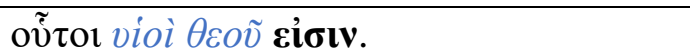 \\
\hline \multirow[t]{5}{*}{ PARTE II } & \multirow{3}{*}{$\begin{array}{c}\text { Segmento } \\
2\end{array}$} & $15 \mathrm{a} \alpha$ & $\mathrm{C}$ & 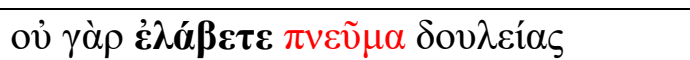 \\
\hline & & $15 \mathrm{~b} \beta$ & $\mathrm{D}$ & 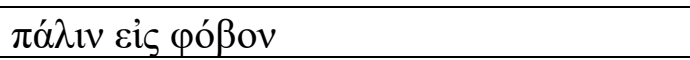 \\
\hline & & $15 \mathrm{c} \gamma$ & $\mathrm{E}$ & $\dot{\alpha} \lambda \lambda \grave{\alpha} \mathbf{\varepsilon} \lambda \boldsymbol{\alpha} \boldsymbol{\beta} \varepsilon \boldsymbol{\tau} \varepsilon \pi v \varepsilon v \tilde{\mu} \mu \alpha$ vio $\theta \varepsilon \sigma i \alpha \varsigma$ \\
\hline & \multirow{2}{*}{$\begin{array}{c}\text { Segmento } \\
3\end{array}$} & $15 \mathrm{~d} \alpha$ & $\mathrm{F}$ & 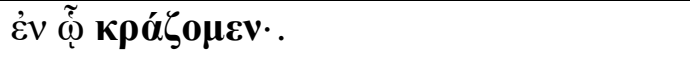 \\
\hline & & $15 \mathrm{e} \beta$ & $\mathrm{G}$ & $\dot{A} \beta \beta \alpha \dot{\alpha} \pi \alpha \tau \eta \dot{\rho} \rho$ \\
\hline \multirow[t]{2}{*}{ PARTE III } & \multirow[t]{2}{*}{$\begin{array}{c}\text { Segmento } \\
4\end{array}$} & $16 a \alpha$ & $\mathrm{G}^{\prime}$ & 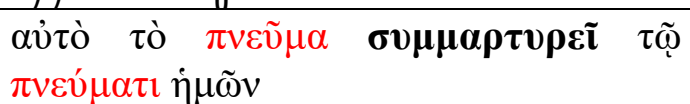 \\
\hline & & $16 \mathrm{~b} \beta$ & $F^{\prime}$ & 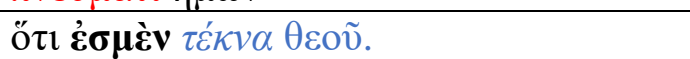 \\
\hline \multirow[t]{5}{*}{ PARTE IV } & \multirow{3}{*}{$\begin{array}{c}\text { Segmento } \\
5\end{array}$} & $17 \mathrm{a} \alpha$ & $E^{\prime}$ & 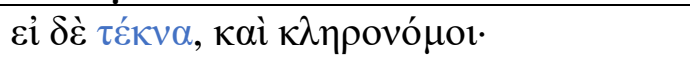 \\
\hline & & $17 \mathrm{~b} \beta$ & $\mathrm{D}^{\prime}$ & 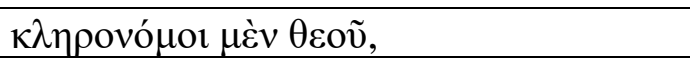 \\
\hline & & $17 \mathrm{c} \gamma$ & $\mathrm{C}^{\prime}$ & $\sigma v \gamma \kappa \lambda \eta \rho о v o ́ \mu o \imath ~ \delta \dot{\varepsilon} \mathrm{X} \rho 1 \sigma \tau о \tilde{v}$ \\
\hline & \multirow{2}{*}{$\begin{array}{l}\text { Segmento } \\
6\end{array}$} & $17 \mathrm{~d} \alpha$ & $\mathrm{B}^{\prime}$ & $\varepsilon i ̈ \pi \varepsilon \rho \sigma 0 \mu \pi \alpha ́ \sigma \chi 0 \mu \varepsilon v$ \\
\hline & & $17 \mathrm{e} \beta$ & $\mathrm{A}^{\prime}$ & 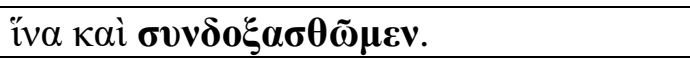 \\
\hline
\end{tabular}

${ }^{64}$ W. GONZAGA. A Sagrada Escritura, a Alma da Sagrada Teologia. In: I. MAZZAROLO; L.A. FERNANDES; M.L.C. LIMA. Exegese, Teologia e Pastoral: relações, tensões e desafios, p. 221. 
Com a aplicação do Método da Análise Retórica e do método Histórico Crítico visualizamos uma divisão tripartida, com 6 segmentos. Na Primeira Parte, que serve de introdução, encontra-se o segmento 1, que apoiando o versículo 13 que

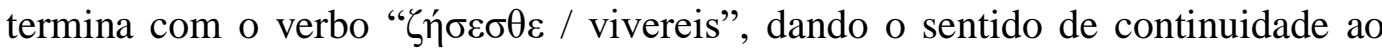
contexto imediato do capítulo 8 da Carta aos Romanos.

A Segunda Parte, composta pelos segmentos 2 e 3, inicia com o segmento trimembro 2, caracterizado pela contraposição em forma de quiasmo entre o

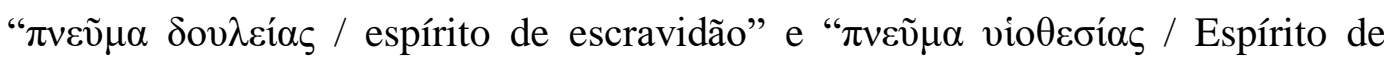
Filiação", onde o medo, fruto da escravidão, abre passagem para a virtude intrínseca

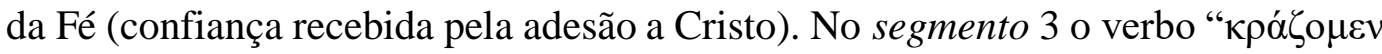

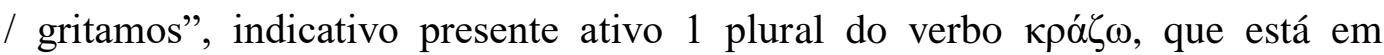
consonância e consequência do ser conduzido pelo Espírito, onde ressoa o hebraísmo A A $\beta \beta \alpha ́$.

$\mathrm{Na}$ Terceira Parte no segmento 4, identificado pelo versículo $16 \mathrm{a} \alpha$ e $16 \mathrm{~b} \beta$,

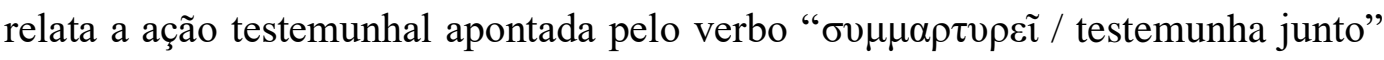
ao nosso espírito a nossa Filiação.

A perícope se conclui na Quarta Parte que traz os segmentos 5 e 6 . No segmento trimembro 5 Paulo expõe a consequência da nossa filiação dada pelo

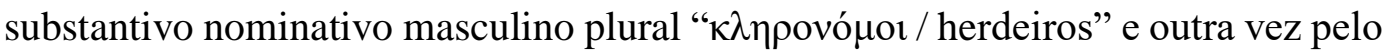

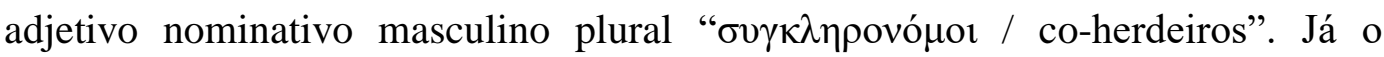
segmento bimembro 6 apresenta as condições necessárias para participarmos da vida divina quando sofremos com Cristo e somos glorificados com Ele. Assim sendo, com a segmentação realizada e tendo obtido uma tradução de nossa perícope chegamos à seguinte estruturação:

\section{PARTE I - A CONDUÇÃO PELO ESPÍRITO GERA FILHOS}

$$
\text { segmento 1: } 14 \mathrm{a} \alpha-14 \mathrm{~b} \beta
$$

PARTE II - O ESPÍRITO E O GRITO $A \beta \beta \alpha \dot{\alpha}$ - PAI

$>$ Segmento 2: o espírito de escravidão e o Espírito de Filiação $(15 \mathrm{a} \alpha-15 \mathrm{c} \gamma)$

Segmento 3: o grito $A \beta \beta \dot{\alpha}$ - Pai $(15 \mathrm{~d} \alpha-15 \mathrm{e} \beta)$

PARTE III - O TESTEMUNHO JUNTO AO NOSSO ESPÍRITO

Segmento 4: $(16 a \alpha-16 b \beta)$ 
PARTE IV - SOFRIMENTO E GLÓRIA

Segmento 5: herdeiro de Deus e co-herdeiro de Cristo (17a $\alpha-$ $17 \mathrm{c} \gamma)$

Segmento 6: sofremos juntos com Ele e glorificamos juntos com Ele $(17 \mathrm{~d} \alpha-17 \mathrm{e} \beta)$

\subsection{Um tema desenvolvido em Rm 8,14-17 e crucial na Carta aos Gálatas}

Para precisarmos a composição retórica no contexto imediato é importante reafirmar o que foi apresentado no tópico “3.1”, que relata a disposição retórica de toda a Carta aos Romanos identificando o nosso texto na segunda metade da sessão "A". Assim sendo, permitindo a retomada de alguns temas que foram citados na estrutura, mas não devidamente detalhados por nós.

Conforme o estudado e o conteúdo disposto no capítulo 8 da Carta aos Romanos, não resta dúvidas que a temática do Espírito Santo tem uma relevância crucial e é um dos temas mais caros ao apóstolo, pois perpassa praticamente toda sua obra magna ${ }^{65}$ :

Esta sessão pode ser subdividida em quatro partes segundo a linha de pensamento. No primeiro estágio 8,1-13, Paulo toma em consideração o conflito entre a 'carne' e o 'Espírito'. Uma vez reconhecida a vitória do Espírito vem exposto em 8,14-17, tudo o que ganha o cristão: a filiação divina que o une a Deus. Não obstante esta situação ser segura, tudo permanece imperfeito até que Deus coloque um fim na história atual do mundo: é isto que sublinha a terceira parte 8,18-30 onde descobrimos as perspectivas escatológicas do apóstolo. Enfim, em 8,31-39, segundo o apóstolo, começa um discurso em defesa do amor de Deus manifestado em Cristo.

Entretanto, esta temática não é somente referida no nosso texto, mas também na Carta que o apóstolo escreveu à comunidade dos Gálatas. Segundo Pitta, para

\footnotetext{
${ }^{65}$ G. BARBAGLIO, La teologia di Paolo. Bologna: EDB, 1999, p. 642: "La parola $\pi v \varepsilon v \tilde{\mu} \alpha$ appare 19 volte in questo capitolo del quale costituisce la parola chiave; "Anche so un rilievo statistico permette d'individuare il centro focale del brano: il vocabolo 'spirito' ricorre 34 volte in Rom, ma più della metà in questo capítolo"; J.A. FITZMYER. La Lettera ai Romani: Commentario criticoteologico, p. 592: "Paolo procede oltre nella sua spiegazione dell'argomento esposto in 5,1-11, mostrando quale sia l'influenza esercitata dello Spirito di Cristo sulla vita cristiana. Lo Spirito non solo abilita il cristiano a far morire le opere del corpo, non solo dà una nuova vita; egli stabilisce per gli uomini un rapporto com Dio in termini di figliolanza adottiva e di eredità. Questa adozione, a sua volta abilita il cristiano a invocare Dio come 'Padre' ed è garanzia del destino escatologico che li attende"; S. LÉGASSE. L'Êpître de Paul aux Romains. Paris: Cerf, 2002, p. 370.
} 
colher a riqueza e originalidade de $\mathrm{Rm}$ 8,14-17 é necessário colocar estes versículos em relação com Gl 4,6-7, pois parecem claramente co-relacionados ${ }^{66}$ :

$\operatorname{Rm} 8,14-17:$

De fato, todos aqueles que são conduzidos pelo Espírito de Deus esses são filhos de Deus. De fato, vós não recebestes um espírito de escravidão, novamente para o medo, mas vós recebestes um Espírito de Filiação, no qual gritamos: Abba, Pai. Ele, o Espírito, testemunha junto ao nosso espírito que somos filhos de Deus. E se filhos, também herdeiros, herdeiros certamente de Deus, isto é, co-herdeiros de Cristo porque juntos com Ele sofremos para também juntos com ele sejamos glorificados.
Gl 4,6-7:

${ }^{6} \mathrm{E}$, porque vós sois filhos, enviou Deus ao nosso coração o Espírito de seu Filho, que clama: Abba, Pai! ${ }^{7} \mathrm{De}$ sorte que já não és escravo, porém filho; e sendo filho, também herdeiro por Deus.

\section{A) Elementos de continuidade}

1. Nos dois textos, vemos a invocação da filiação: Abba, Pai, com a transliteração semítica e a tradução grega.

2. Em Gl 4,6 e em Rm 8,15-16 é expressa uma estreita relação entre o Espírito e a filiação, entre filiação e herança.

\section{B) Elementos de descontinuidade}

1. O processo diverso entre o grito e o Espírito, ou seja, em Gl 4,6 o Espírito clama em nós, já em Rm 8,15 nós gritamos no Espírito.

\footnotetext{
${ }^{66}$ A. PITTA. Lettera ai Romani: Nuova versione, introduzione e commento. LBNT 6. Milano: San Paolo, 2001, p. 294-295.
} 
2. Acentuação relacional: em Gl 4,6 é mais explícita a relação entre Espírito e o Filho de Deus, já em Rm 8,17 a acentuação é mais entre a herança de Cristo e a nossa.

\section{C) Novidades em Rm 8,14-17 que não se encontram em Gl 4,6-7}

v.14: a condução é obra do Espírito

v.15a: a oposição entre o espírito do medo e o espírito de filiação

v.16: o testemunho do Espírito de Deus ao nosso espírito

v.17b: a participação no Sofrimento e na Glória

Por um lado, desta relação podemos colher algumas informações que corroboram à temática do Espírito e da Filiação nas duas Cartas, entretanto, por outro, há um claro desenvolvimento na Carta aos Romanos que demonstra o quanto foi importante para o Apóstolo Paulo esta comunidade e quão grande foi a necessidade de esmiuçar essas temáticas.

Os critérios que delineiam a continuidade mostram a consonância temática na qual é desenvolvida as duas perícopes. Todavia, a dimensão da relação e colaboração humana é acentuada mais na Carta aos Romanos onde o Apóstolo dos Gentios indica a importância da ação do homem que, escolhendo viver conduzido pelo Espírito Santo, recebe no Batismo a Filiação que nos foi dada por Cristo Jesus, nos fazendo participantes hoje do seu sofrimento para participarmos amanhã da sua glória nos céus.

Assim sendo, podemos acolher a opinião defendida por Pitta quando afirma que as novidades propostas na Carta aos Romanos nos induzem a termos presente que no texto de Gl 4,6-7 se encontra a fórmula original de envio do Espírito, à qual Paulo desenvolve aqui, em $\operatorname{Rm} 8,14-17^{67}$.

\footnotetext{
${ }^{67}$ A. PITTA. Lettera ai Romani: Nuova versione, introduzione e commento, p. 294.
} 


\section{Comentário Exegético de $\mathrm{Rm} 8,14-17$}

\subsection{A CONDUÇÃO PELO ESPÍRITO GERA FILHOS}

$4.1 .1 \mathrm{v} .14 \mathrm{a} \alpha$

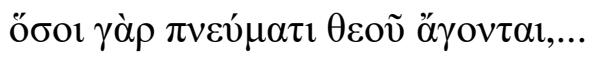

De fato, todos aqueles que são conduzidos pelo Espírito de Deus, ...

O v.14 começa com uma proposição didascálica em terceira pessoa: “őбor

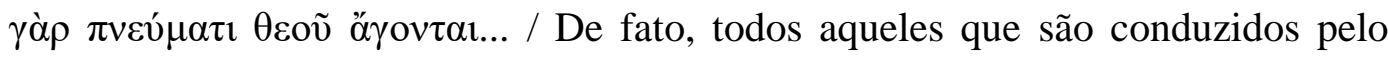
Espírito de Deus, ..." A pergunta retórica que podemos fazer no início da nossa reflexão é: Qual será a vida daqueles que no Espírito mortificam as obras da carne? Com a devida interrogação, podemos já entrar na reflexão tendo presente que toda a argumentação será orientada à herança, no v. 17, e que há uma conexão com

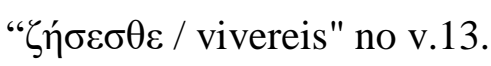

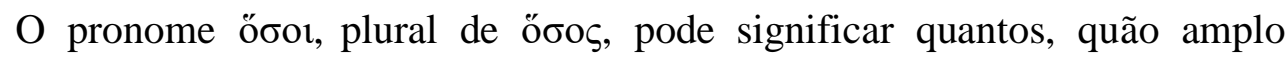
(também no sentido de igualdade) e quão longo (também no sentido de tempo). No NT este termo aparece 110x, quase sempre no nominativo ou acusativo. Pode ter valência de espaço (1), de tempo (2), ${ }^{68}$. Por exemplo ${ }^{69}:$ 1) quando o autor do Livro do Ap 21,16 descreve o evento no qual o anjo mostra a Jerusálem messiânica. Aqui

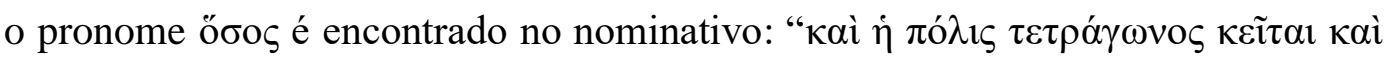

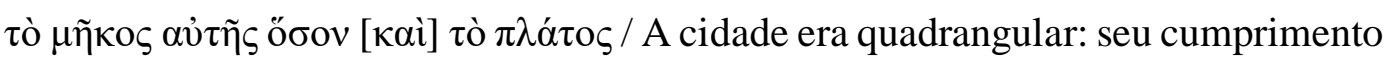
é igual à largura"; 2) neste caso sobre o discurso feito por Jesus no Evangelho de

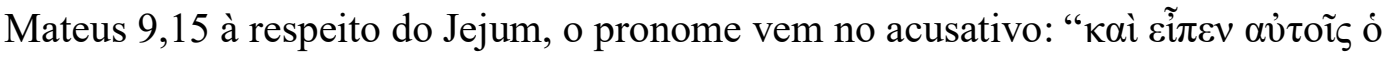
'I

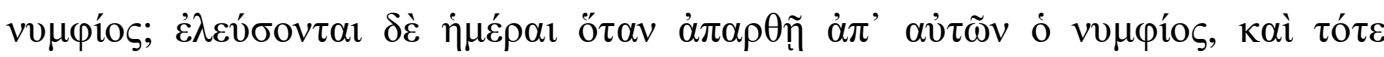

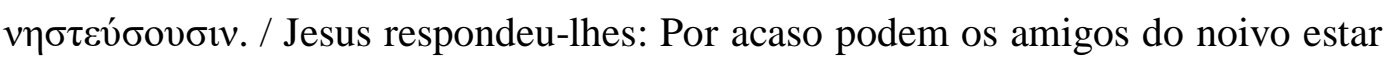
de luto enquanto o noivo está com eles? Dias virão, quando lhes será tirado; então, sim, jejuarão."

\footnotetext{
${ }^{68}$ W. RADL. őбoৎ. In: H. BALZ; G. SCHNEIDER. Dizionario Esegetico del NT. Brescia: Paideia Editrice, 2004, p. 661.

${ }^{69}$ Para os exemplos de citações bíblicas, serão adotados os textos de acordo com a tradução proposta pela de Bíblia de Jerusalém. São Paulo: Paulus, 1995.
} 
O termo ő $\sigma o ı$ pode obter um sentido de força restritiva: "somente aqueles que", como diz Lagran Michel ${ }^{70}$ e como sugere o v.13. Porém, pode obter também um sentido de força inclusiva: "todo aquele que" como defendem Cranfield"1, Schlier $^{72}$, Fitzmeyer ${ }^{73}$ e Dunn ${ }^{74}$. Já Käsemann ${ }^{75}$ faz prevalecer os dois significados, ou seja, dependendo da situação podemos obter um ou outro significado.

O termo ressoa como ambiguidade deliberada. Porém, é a dependência ao Espírito que decide se esta é uma afirmação com implicações inclusivas, além dos limites de Israel, e restritivas, determinada pela extensão do Espírito fora do povo, ou seja, além dos limites do povo de Israel, atingindo assim outros povos.

Também muito importante é a ocorrência de $\gamma$ óp, pois é a quarta conjunção

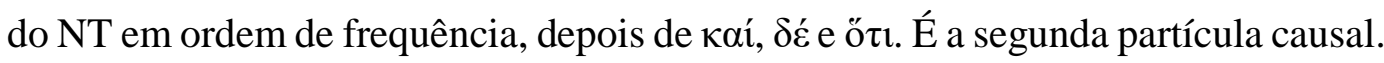
No complexo lexical encontra-se em 1042 passos, especificamente em Mateus, nos escritos paulinos, na 2 Pedro e em Hebreus, com siginificado de "de fato, porque, em seguida e portanto" 76 .

A conjunção yà $\rho$ indica uma relação causal entre duas expressões onde aquela que prossegue, motiva ou explica aquela que precede. Com grande frequência pressupõe uma inexpressada e maravilhada reação do ouvir, no qual o entendimento pode-se deduzir da motivação ou pode ser usado também como reforço para uma pergunta. Porém, existem alguns casos, que não obstante tantas tentativas, não se consegue dar uma interpretação plausível sobre o verdadeiro sentido de yó $\rho$ se é de reforço ou se é de motivação, como nos recorda Pridik ${ }^{77}$.

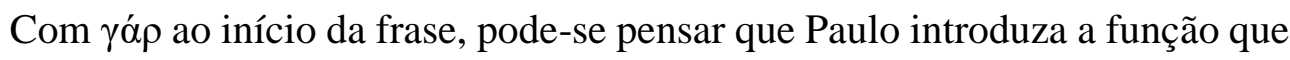
o Espírito Santo tem de guia para as mortificações ${ }^{78}$ das ações do corpo àqueles que creem (cf. v.13). Assim diz Pitta que não obstante essa conexão, a afirmação do

${ }^{70}$ LAGRAN MICHEL apud J.A. FITZMYER. La Lettera ai Romani: Commentario criticoteologico, p. 595.

${ }^{71}$ C.E B. CRANFIELD. Carta aos Romanos. GCB. São Paulo: Paulinas, 1992, p. 181.

${ }^{72}$ H. SCHLIER. La Lettera ai Romani. Brescia: Paideia Editrice, 1982, p. 416.

${ }^{73}$ J.A. FITZMYER. La Lettera ai Romani: Commentario critico-teologico, p. 595.

${ }^{74}$ J.D.G. DUNN. Romans 1-8. WBC 38. Dallas: Word Books, 1988, p. 450.

${ }^{75}$ KÄSEMANN apud J.A. FITZMYER. La Lettera ai Romani: Commentario critico-teologico, p. 595.

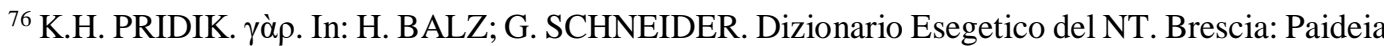
Editrice, 2004, p. 628-629.

${ }^{77}$ K.H. PRIDIK. $\gamma \grave{\alpha} \rho$. In: H. BALZ; G. SCHNEIDER. Dizionario Esegetico del NT, p. 629-630.

78 J.A. FITZMYER. La Lettera ai Romani: Commentario critico-teologico, p. 1116: "La mortificazione, pur essendo necessaria per la vita del cristiano non è propriamente costitutiva. $\mathrm{E}$ piuttosto lo Spirito ad animare, rendere attivo il cristiano e costituirlo figlio di Dio"; W. HENDRIKSEN. Comentário do Novo Testamento - Romanos. São Paulo: Editora Cultura Cristã, 2011, p. 323. 
v.14 é peculiar, sem referimentos explícitos a tudo que podemos fazer por meio do Espírito. Por isso, aqui nos deparamos com uma sentença geral que introduz a relação entre o Espírito Santo e a nossa filiação divina sem explicitar algum complemento de relação: como guiados, de onde e em que direção ${ }^{79}$ ?

Quando falamos de guiados pressupomos a presença de alguém que guia. Assim entramos no coração de nossa dissertação, pois é o Espírito Santo o protagonista da nova vida. O nosso texto exprime a pessoa do Espírito Santo com a palavra $\pi v \varepsilon v \tilde{\mu} \alpha$ e seus derivados, de modo particular $\pi v \varepsilon v ́ \mu \alpha \tau \imath^{80}$.

A palavra $\pi v \varepsilon v ́ \mu \alpha \tau \imath$ vem de $\pi v \varepsilon v \tilde{\mu} \alpha$, que, por sua vez, é derivada da palavra $\pi v \varepsilon ́ \omega$ que designa a força elementar da natureza e da vida: vento, sopro, respiro como princípio da vida, equivalente ao termo " $\psi v \chi \eta ́$ / alma”, junto com matéria e acontecimento $^{81}$.

Dentro do contexto bíblico da Carta aos Romanos, sobretudo no capítulo 8, sabemos que o Espírito Santo é um tema fundamental, pois o apóstolo Paulo pode constatar várias vezes na sua experiência pessoal e nas comunidades com as quais ele teve contato, além de que também o "Espírito é a ponte de comunicação entre

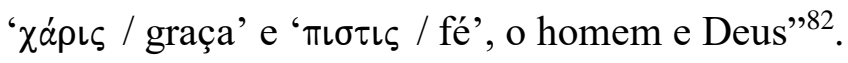

A este ponto encontramos duas correntes que interpretam diversamente o ser guiado pelo Espírito. Uma é aquela de Pitta $^{83}$ e Zeller ${ }^{84}$, que dá uma interpretação exodal ao texto, e outra é aquela de Légasse ${ }^{85}$ que, não obstante encontrar vocabulários de caráter exodal, defende como excessiva uma tal tipologia.

\footnotetext{
${ }^{79}$ A. PITTA. Lettera ai Romani: Nuova versione, introduzione e commento, p. 295.

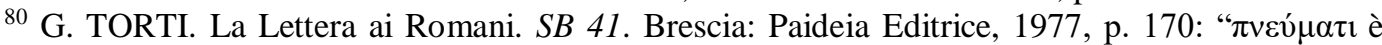
dativo d'agente".

${ }^{81}$ J. KREMER. $\pi v \varepsilon \tilde{\mu} \mu \alpha$. In: H. BALZ; G. SCHNEIDER. Dizionario Esegetico del NT. Brescia: Paideia Editrice, 2004, p. 1011.

${ }^{82}$ G.F. RAVASSI. La Lettera ai Romani, Bologna: Edizioni Dehoniane Bologna, 1990, p. 52.

${ }^{83}$ A. PITTA. Lettera ai Romani: Nuova versione, introduzione e commento, p. 295: "In questa sequenza comincia la relazione con il modello esodale: dalla schiavitù alla liberazione, all'elezione e alla partecipazione della terra promessa. La schiavitù del popolo ebraico in Egito rappresenta il contesto storico paradigmatico sia per la condizione servile esilica, come nel profetismo dell'AT, sia per la schiavitù sotto il dominio del peccato, come per tutti coloro che non sono in Cristo. Come Israele è stato liberato dall'Egitto così i credenti sono liberati dal peccato e dalla morte, e questa libertà conduce all'elezione. Trasferendo il modello esodale alla vita cristiana, siamo guidati dallo Spirito perchè siamo stati liberati dalla legge del peccato e della morte $(\operatorname{Rm~} 8,2)$; e questa guida si esprime nella figliolanza divina. L'uso del verbo 'sono guidati' che trova nel linguaggio familiare

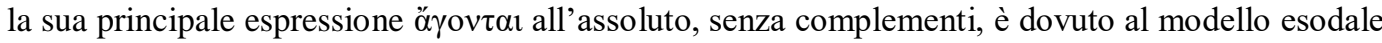
sottostante: 'Il Signore lo guidò da solo, non c'era con lui alcun dio straniero' (Deut 32,12)".

${ }^{84}$ D. ZELLER. Lettera ai Romani. Brescia: Paideia Editrice 1998, p. 250.

${ }^{85}$ S. LÉGASSE. L'Épître de Paul aux Romains, p. 504: "Parler à propos de ce verset de typologie exodiale est excessif. I. de la Potterie, qui défend à juste titre l'exégèse dynamique de Rom 8,14, signale dans Rom 8 la présence de 'grands thèmes du cycle de l'Exode [...] utilisés typologiquement'
} 
Ambrogio Spreafico, num comentário sobre o livro do Êxodo ${ }^{86}$, fala que a Páscoa marcou tanto a fé de Israel quanto a dos cristãos, pois esta transformou-se a partir da experiência, no coração da fé destas tradições religiosas. A Páscoa manifesta a memória na qual o passado, o presente e o futuro unem-se para afirmar o poder da salvação de Deus, que com sua Dicensus Dei liberta o homem da escravidão e da morte, proporcionando àquele que aderir a esta vida nova a filiação divina. Partindo desta certeza, parece-me prudente ter presente que a opinião sustentada por Pitta $^{87}$ e Zeller ${ }^{88}$ é mais plausível, com o processo de continuidade que liga um Testamento ao outro no projeto de salvação da humanidade, não obstante, no seu comentário não apresente, como Légasse ${ }^{89}$, os vocabulários que correlacionam o nosso texto com a cultura exodal, pois o seu intuito é mostrar-nos que todos aqueles que se deixam conduzir pelo Espírito Santo participam de uma vida nova, caracterizada pela filiação divina. Todavia, vejo justo que também podemos encontrar uma grande descontinuidade ${ }^{90}$ que é aquela sustentada por Légasse $^{91}$, quando nos recorda que o papel do Espírito Santo enquanto ligado à filiação divina é de fato dependente de Jesus, pois aqui não estamos falando de um homem qualquer (cf. Mt 1,20-23; Lc 1,30-31; 2,1-21), mas do Filho Unigênito de Deus, o Verbo Encarnado do Pai.

O texto indica que todos que se deixam conduzir pelo Espírito esses são os mesmos que mortificam as obras do corpo. A mesma duplicidade e unidade

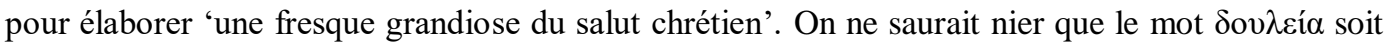
un de ceux qui, dans les Septante désignent la 'servitude' égyptienne ni que le verbe ớ $\gamma \varepsilon ı v$ n'y soit employé à propos de la conduite des Hébreux dans le désert. Les titres de 'fils' et d'héritier de Dieu sont appliqués à Israël et, quant à l'Esprit, le Trito-Isaïe en fait le guide de la marche vers la Terre promise. Mais relever ces contacts et les accumuler n'obligent pas à attribuer à Paul l'idée d'un nouvel Exode vécu par les chrétiens sous l'action de l'Esprit. D'une part, en effet, notions et vocabulaire ne sont pas, dans la Bible grecque, localisés uniquement dans le cadre exodial. D'autre part, pour Paul et selon sa théologie, le rôle de l'Esprit comme constitutif de la filiation divine - tel est ici le thème essentiel - n'a rien d'exodial et n'est même pas proprement biblique, mais il dépend essentiellement de la christologie: du titre et de la qualité de 'Fils de Dieu' attribués à Jésus par la première génération chrétienne découle une analogie pour ceux qui se réclament de lui et lui sont unis par le foi. L'intervention de l'Esprit en l'occurrence se rattache non à l'Exode, mais aux annonces prophétiques du rôle de l'Esprit aux derniers temps".

${ }^{86}$ A. SPREAFICO. El Libro del Éxodo. Barcelona: Editorial Herder, 1995, p. 81.

${ }^{87}$ A. PITTA. Lettera ai Romani: Nuova versione, introduzione e commento, p. 295. (vide nota 82)

${ }^{88}$ D. ZELLER. Lettera ai Romani, p. 250.

${ }^{89}$ S. LÉGASSE. L'Épître de Paul aux Romains, p. 504. (vide nota 85)

${ }^{90}$ A. PITTA. Lettera ai Romani: Nuova versione, introduzione e commento, p. 295-296: "Tuttavia, a causa del modello esodale, non bisogna cadere in una visione sostitutiva, nel senso che i cristiani adesso prenderebbero il posto dell'Israele di Dio; tanto meno si può ignorare la novità dell'affermazione paolina, per la quale si procede dalla guida dello Spirito alla figliolanza divina".

${ }^{91}$ S. LÉGASSE. L'Épître de Paul aux Romains, p. 504. (vide nota 84) 


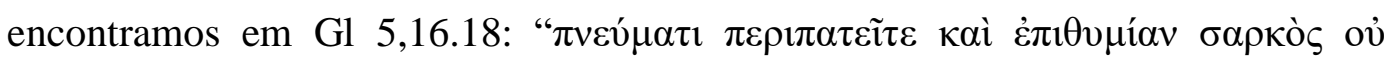
$\tau \varepsilon \lambda \varepsilon ́ \sigma \eta \tau \varepsilon$ / conduzi-vos pelo Espírito e não satisfarei os desejos da carne" e "cỉ [...] $\pi v \varepsilon v ́ \mu \alpha \tau \iota ~ \alpha ̋ \gamma \varepsilon \sigma \theta \varepsilon$ / se [...] vos deixeis guiar pelo Espírito”. O agir do Cristão é sempre um submeter-se e uma decisão de ser guiado pelo Espírito Santo, justamente porque o mesmo Espírito vive em nós pelo Batismo e mortifica em nós as ações egoísticas, solicitando-nos a deixar-nos guiar por Ele, pois tudo é feito Nele e por Ele em nós. Fitzmyer declara que: "ser guiados pelo Espírito é o modo no qual Paulo exprime o que depois os teólogos chamarão de Gratia praeveniens, ou melhor, a iniciativa que Deus assume em guiar a vida cristã"92.

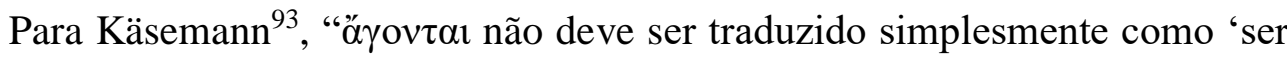
guiados', mas como ser conduzidos pelo Espírito”. Deveras, o verbo ö $\gamma \omega^{94}$ que dá origem à voz ä $\gamma o v \tau \alpha \iota$ pode ser traduzido de outras formas dependendo do contexto,

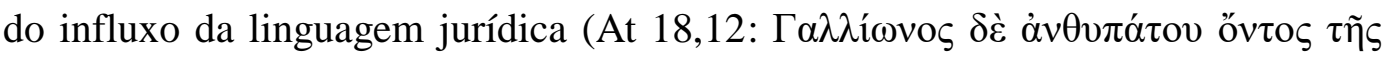

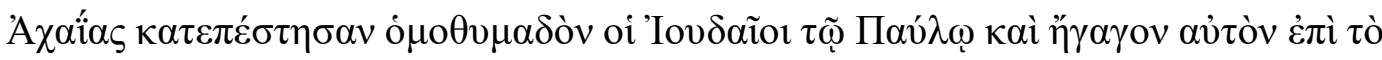
$\beta \tilde{\eta} \mu \alpha$ / Sendo Galião procônsul da Acaia, os judeus levantamram-se unanimente

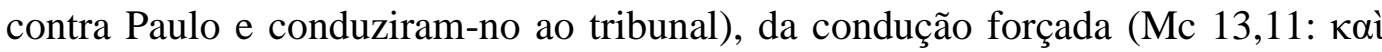

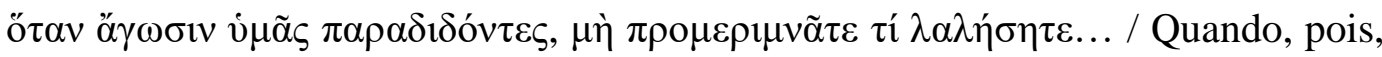
vos levarem para vos entregar, não vos preocupeis com o que havereis de dizer...; cf. Lc 4,40; 10,34; 18,40; 22,54 Jo 7,45; 9,13; 10,16; At 5,26; 20,12), tb com o valor

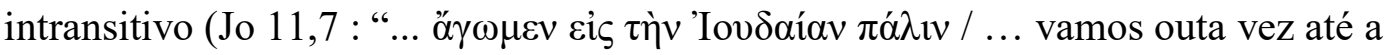
Judeia") e etc. O verbo ó $\gamma \omega$ pode ser traduzido como: "conduzir", "traduzir", "levar", "arrastar", "puxar" e "necessidade de ser conduzido" (Mt 21,2.7; Lc 19,30.35; At 8,32). Segundo Fitzmyer ${ }^{95}$, a interpretação de Käsemann também não é segura:

... de modo algum é segura, pois Schlier nos mostra que Paulo utiliza o verbo á $\gamma \varepsilon \sigma \theta \varepsilon$, somente em G1 5,18, onde "ser guiados pelo Espírito" é paralelo a "caminhar segundo o Espírito" (Gl 5,16). Em todo caso é esta a modalidade pela qual Paulo recorre para exprimir a influência ativa que exercita o Espírito de Cristo na vida daquele que crê, isto é, a reação dos cristãos guiados pelo Espírito.

\footnotetext{
${ }^{92}$ J.A. FITZMYER. La Lettera ai Romani: Commentario critico-teologico, p. 594.

${ }^{93}$ KÄSEMANN apud J. A. FITZMYER. La Lettera ai Romani: Commentario critico-teologico, p. 594; W. HENDRIKSEN. Comentário do Novo Testamento - Romanos, p. 325.

${ }^{94}$ U. BORSE. ö $\gamma \omega$. In: H. BALZ; G. SCHNEIDER. Dizionario Esegetico del NT. Brescia: Paideia Editrice, 2004, p. 64-65.

${ }^{95}$ J.A. FITZMYER. La Lettera ai Romani: Commentario critico-teologico, p. 594.
} 


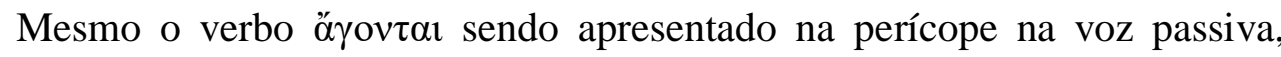
podemos assumir seu valor na voz média ${ }^{96}$ obtendo o significado deixando-se conduzir pelo Espírito para corresponder o v. 14 com a terminação do v. 13b que propõe ao cristão uma escolha e não interpretrar como uma visão extática ${ }^{97}$, sem movimento e contribuição do ser humano. Por essa razão, Wilckens ressalta que: "como o mortificar é possível deixando-se conduzir pelo Espírito de Deus (no lugar

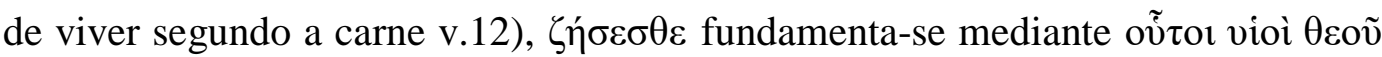
Eioıv / esses são filhos de Deus"98.

\section{$4.1 .2 \mathrm{v} .14 \mathrm{~b} \beta$}

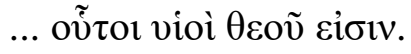

... esses são filhos de Deus.

A presença do Espírito guia e inspira a vida daqueles que creem, garantindo a eles a dignidade de filhos de Deus ${ }^{99}$. No AT, a filiação divina era um privilégio de Israel, enquanto povo eleito para viver a comunhão com Deus (Ex 4,2; Dt 32,6; Is 63,16$)^{100}$. Schiler ${ }^{101}$ e Cranfrield ${ }^{102}$ afirmam que o objetivo do enunciado no v.14

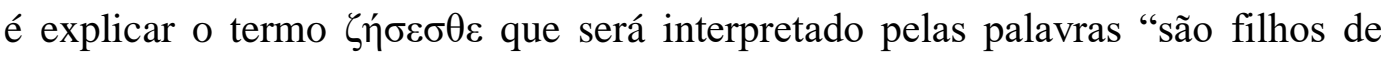
Deus".

O pronome demonstrativo "oṽ $\tau$ / esses" aparece 1391x no NT e indica o que existe diante daquele que fala ou escreve ${ }^{103}$. Este pronome é usado

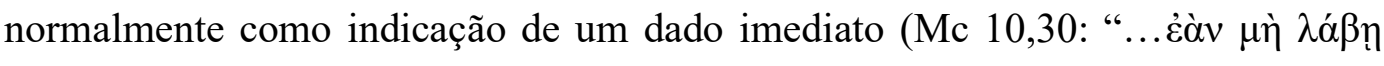

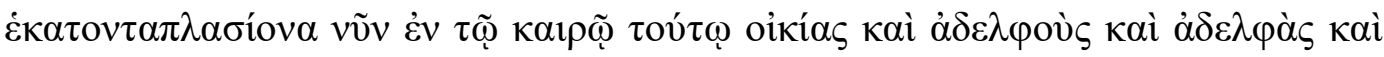

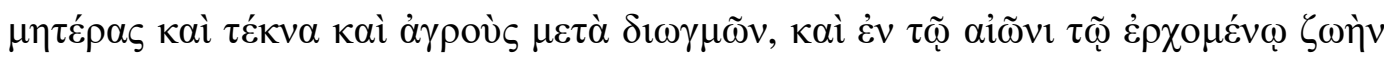
aíovıv / ...que não receba cem vezes mais desde agora, neste tempo, casas, irmãos

\footnotetext{
${ }^{96}$ U. WILCKENS. La Carta a los Romanos 6-16 (II), p. 169.

${ }^{97}$ R. PENNA. Lettera ai Romani: Rm 6-11 (II). Scritti delle origini Cristiane 6, Bologna: Edizioni Dehoniane Bologna, 2006, p. 159. Romano Penna adota a voz passiva no verbo conduzir, todavia afirma que não implica uma inatividade ou inércia do cristão, pois o versículo precedente formula uma condição de escolha para o receptor da mensagem apóstolica.

${ }^{98}$ U. WILCKENS. La Carta a los Romanos, 6-16 (II), p. 169.

${ }^{99}$ K. KERTELGE. A Epístola aos Romanos. Petrópolis: Vozes, 1982, p. 151.

100 J.D.G. DUNN. Jesus y el Espíritu. Jesus y el Espíritu. Comentario a la Epístola de Romanos. Barcelona: Editorial Clie, 2014. p. 557.

${ }^{101}$ H. SCHLIER. La Lettera ai Romani, p. 416

102 C.E.B. CRANFIELD. Carta aos Romanos, p. 180.

${ }^{103}$ T. HOLTZ. oṽ $\tau$ s. In: H. BALZ; G. SCHNEIDER. Dizionario Esegetico del NT, p. 691.
} 
e irmãs, mães e filhos e terras, com perseguições"; cf. Lc 18,30) e como indicativo

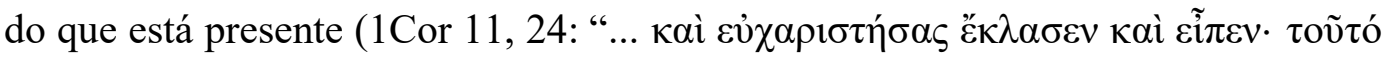

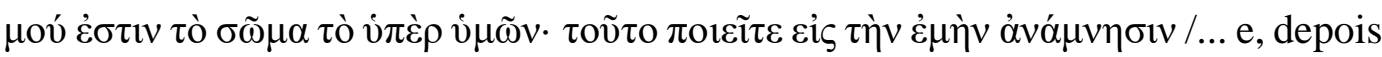
de dar graças, partiu-o e disse: Isto é o meu corpo, que é par vós; fazei isto em memória de mim") ${ }^{104}$.

Segundo A. Sacchi ${ }^{105}$, no limiar da era cristã eram sobretudo os justos designados como "filhos de Deus" (Sb 2,13). Depois Jesus, por sua dignidade messiânica, é proclamado Filho de Deus de modo único e irrepetível (Rm 1,3-4). Entretanto, agora esta dignidade é doada através do Espírito àqueles que creem nele e deixam-se guiar por Ele.

O termo "vioì / filhos" aparece 379x no NT, é estreitamente semelhante a

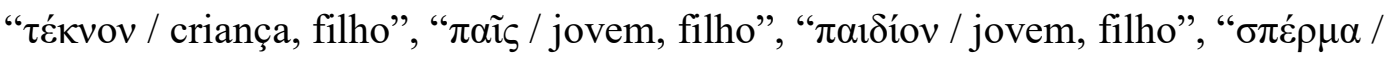
sêmen, descedência”. Este termo pode ser usado para falar de filhos carnais, de um nexo genealógico e como título cristológico. Com relação ao último uso do termo existem três concepções ${ }^{106}$ :

- a filiação de Jesus é fundada na relação com Deus como Pai;

- a constituição como filho de Deus é em sentido messiânico concretizado no ofício de Salvador;

- a filiação divina comporta uma afirmação de essência sobrenatural divina.

Como vimos, o termo "vióc / filho" pode designar seja filiação divina ${ }^{107}$ seja humana. De modo concreto, o que interessa trabalharmos é a primeira concepção

\footnotetext{
${ }^{104}$ T. HOLTZ. oṽ tos. In: H. BALZ; G. SCHNEIDER. Dizionario Esegetico del NT, p. 691-692. 105 A. SACCHI. Lettera ai Romani, p. 137. ${ }^{106}$ F. HAHN. viós. In: H. BALZ; G. SCHNEIDER. Dizionario Esegetico del NT. Brescia: Paideia Editrice, 2004, p. 1688-1691.

107 L.W. HURTADO. Figlio di Dio. In: G.F. HAWTHORNE; R.P. MARTIN; D.G. REID. Dizionario di Paolo e delle sue Lettere Cinisello Balsamo: San Paolo Edizioni, 2000, p. 615-616: "A figliolanza divina di Gesù è una delle principali componenti della cristologia di Paolo, sebbene nelle sue lettere i riferimenti a Gesù come 'Figlio' di Dio siano notevolmente inferiore alle molte designazioni di Gesù come 'Signore' e 'Cristo'. Alcuni hanno affermato che l'idea della figliolanza divina di Gesù fosse appropriazione di tradizioni religiose pagane e che Paolo presentasse con ciò Gesù secondo un modello di divinità cultuali greco-romane, ma le testimonianze sullo sfondo religioso pagano e l'uso da parte di Paolo del linguaggio del 'Figlio' divino vanno in senso contrario a questa affermazione. Paolo non usava principalmente il linguaggio della figliolanza divina per affermare la divinità di Gesù. I suoi riferimenti a Gesù come 'Figlio' di Dio esprimevano essenzialmente lo status unico di Gesú e la sua intima relazione con Dio".
} 
que nos permite participar da vida divina por intermédio de Jesus Cristo, o Filho Unigênito de Deus.

O AT conhece, além da designação dos seres celestes como "Filhos de Deus" e do uso messiânico de "Filho de Deus", um emprego do motivo da filiação divina referido a Israel (Ex 4,22: Então dirás a Faraó: “Assim fala o Senhor: Meu filho primogênito é Israel. Eu te digo: Deixa partir meu filho para que me sirva...") ${ }^{108}$. Já no âmbito do judaísmo helenístico esta tendência é mais clara como demonstra o livro da Sabedoria 2,13.18: "Declara ter conhecimento de Deus e se diz filho do Senhor; Pois se o justo é filho de Deus, Ele o assitirá e o libertará das mãos de seus adversários". 109

Nos evangelhos sinóticos esse motivo aparece esporadicamente. Já na tradição joanina é claro que se trata de um bem salvífico presente: 1Jo 3,2a “...vṽv

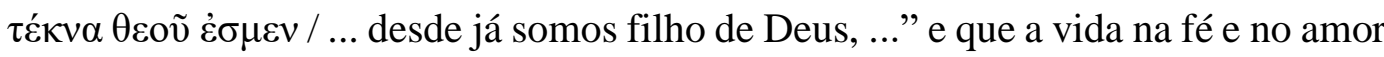
é a característica desta realidade.

Nos escritos do NT atribuídos a Paulo, o título de Filho de Deus não é fixo nem frequente, pois aparece $17 \mathrm{x}(\operatorname{Rm} 1,3-4.9 ; 5,10 ; 8,3.29 .32$; 1 Cor 1,9; 15,28; 2 Cor 1,19; Gl 1,16; 4,4.6; 2,20; Ef 4,13; Cl 1,13; 1Ts 1,10) e nem sempre com a mesma ordem da palavra grega. Todavia o que é importante para Paulo é a convicção de que Jesus é Filho de Deus. Isso significa que Jesus possui uma posição, um status e uma graça única junto a Deus ${ }^{110}$. Também a filiação divina vem proposta no final dos tempos como um bem prometido ( $\mathrm{Rm}$ 8,18-19: "Penso, com efeito, que os sofrimentos do tempo presente não têm proporção com a glória que deverá revela-se em nós. Pois a criação em expectativa anseia pela revelação dos filhos de Deus").

Em Gl 4,4 Paulo sublinha que o Filho Divino aparece em forma humana

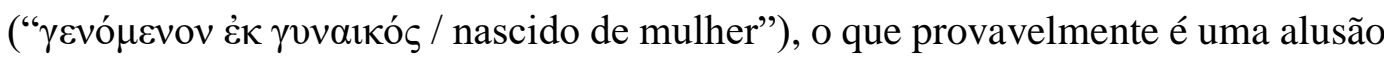
à ideia da encarnação do Filho "preexistente" (Jo 1,1-18), onde sua dimensão

\footnotetext{
${ }^{108}$ F. HAHN. vióc. In: H. BALZ; G. SCHNEIDER. Dizionario Esegetico del NT, p. 1699: “Os. 2,1; Is., Jer., in Deutero/Trito Is. e in Deut. Si tratta sempre dell' elezione di Israele e della cura premurosa del Padre"; A tradução adotada foi da Bíblia. Bíblia Tradução Ecumênica. São Paulo: Edições Loyola, 1994.

${ }^{109}$ F. HAHN. vióc. In: H. BALZ; G. SCHNEIDER. Dizionario Esegetico del NT, p. 1699.

110 L.W. HURTADO. Figlio di Dio. In: G.F. HAWTHORNE; R.P. MARTIN; D.G. REID.

Dizionario di Paolo e delle sue Lettere, p. 620-621.
} 
humana e morte liberta a humanidade da limitação da Torá abrindo-se ao novo da revelação divina ${ }^{111}$.

Muito frequente no NT é o nominativo (ó) " $\theta \varepsilon o ́ \varsigma /$ Deus", que aparece com ou sem o artigo determinativo. A práxis judaica de evitar o nome de Deus ${ }^{112}$ através de um vocábulo é também encontrada no NT, mas não é aplicada sistematicamente, pois $\theta \varepsilon o ́ \varsigma$ não é o verdadeiro nome de Deus, mas um conceito predicativo que indica a divindade.

Na história das religiões, o termo $\theta \varepsilon o ́ \varsigma$ (Mt 16,16; 26,63; Jo 3,33; 6,57; 17,3; At 7,40; 8,9ss; 12,22; 14,11ss; 17,18ss; 19,23ss; Rm 1,18-23; 3,4; 15,6; 1Cor 8,4$6 ; 10,10 ; 2$ Cor 2,17; 3,3; 6,16; 11,31; Ef 3,2; Gl 1,1.3ss; 4,8ss; 1Tes 1,9; 1Jo 5,20; Ap 1,8) é ligado à doutrina sobre o Deus da idade helenística, contudo com a diferença de acolher o monoteísmo e lutar contra o politeísmo. Por outro lado, a interpretação neotestamentária de Deus e do seu agir é o fundamento da separação entre Judaísmo e Cristianismo.

Do ponto de vista conceitual no NT e, de modo geral, no mundo antigo, já se pressupõe historicamente a existência de Deus, todavia o termo $\theta \varepsilon$ ćs não indica propriamente a existência de Deus senão sua presença, sua epifania. Por esta razão, no culto o homem invoca Deus e experimenta a sua presença (1Cor 14,24ss). O substantivo $\theta \varepsilon$ ć pode ser aplicado também à divindade não cristã (At 7,40.43:

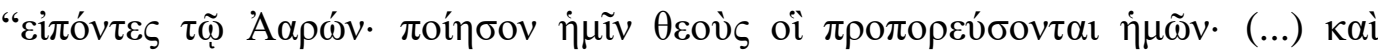

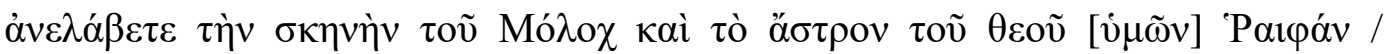
disseram a Aarão : faze-nos deuses que caminhem a nossa frente (...) Entretanto carregastes a tenda de Moloc e a estrela do deus Refã" ; cf. At 19,37; 2Ts 2,4) ${ }^{113}$ a

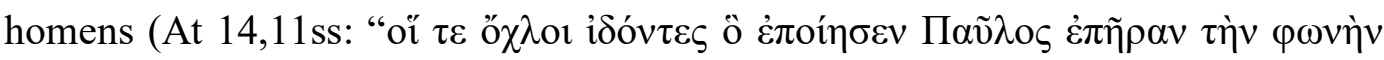

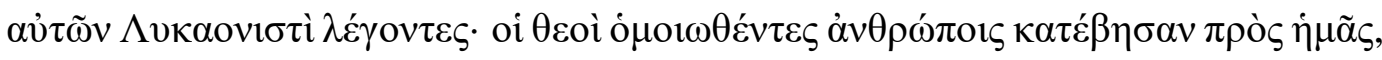
/ Vendo o que Paulo fizera, as multidões levantaram a voz em língua licaônica,

111 L.W. HURTADO. Figlio di Dio. In: G.F. HAWTHORNE; R.P. MARTIN; D.G. REID. Dizionario di Paolo e delle sue Lettere, p. 624.

${ }^{112}$ D.N. FREEDMAN. ירוגו . In: G.J. BOTTERWECK; H. RINGGREN. Grande Lessico dell'AT, vol. III. Brescia: Paideia Editrice, 2003, p. 622: "Il Tetragramma jhwh è il nome proprio del Dio di Mosè. La pronuncia corretta del nome andò persa nella tradizione giudaica medievale. Già nella tarda epoca del secondo tempio il nome divenne sacro in quanto ineffabile e quindi si ritenne di non pronunciarlo nella lettura pubblica ad alta voce, sebbene venisse ancora usato in privato"; De modo geral todos os conceitos da linguagem humana, todo o mundo da imaginação e os atributos podem ser aplicadas a Deus somente em metáfora.

${ }^{113}$ H.D. BETZ. $\theta \varepsilon o ́ c$. In: H. BALZ; G. SCHNEIDER. Dizionario Esegetico del NT. Brescia: Paideia

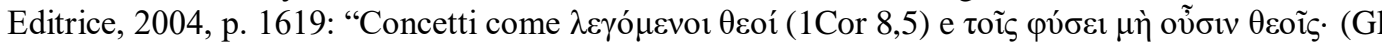
$4,8)$ si possono interpretare sulla base della filosofia ellenistica della religione". 
dizendo: "deuses em forma humana desceram até nós!"; cf. At 28,6), entretanto, essa perspectiva é rejeitada pois é fundamentalmente pagã. Por fim, como imagem

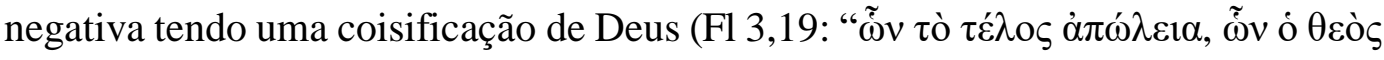

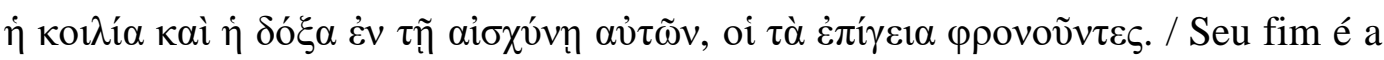
destruição, seu deus é o ventre, sua glória está no que é vergonhoso, e seus pensamentos no que está sobre a terra") onde os deuses dos adversários são o ventre.

É quase impossível tentar exprimir de modo conciso e sintético o pensamento de Paulo sobre Deus; mesmo se necessário, seria muito arriscado por tantos $\operatorname{motivos}^{114}$ :

- primeiro, porque o pensamento de Paulo aqui apenas, primordialmente, não é sistemático nem mesmo especulativo, mas os seus ensinos têm o objetivo de responder às necessidades das comunidades;

- segundo, porque ele afirma sempre refletir o "pensamento de Cristo" (1Cor $2,16)$ e espera que os seus discípulos ou filhos na fé façam o mesmo;

- terceiro, porque as cartas de Paulo foram escritas para as comunidades reunidas para o culto e devem ser lidas em voz alta (Col 4,16 e 1Tes 5,27);

- quarto, porque grande parte da fé de Paulo pertencia às suas crenças judaicas e era a base das suas ideias e do seu modo de viver.

Enfim, a doutrina sobre Deus é fundamental em todo o corpus paulino. Existe muitas afirmações sobre Deus como "Pai e Criador" (Rm 1,20: Sua realidade invisível, seu eterno poder e sua divindade tornou-se inteligível, desde a criação do mundo; 1Cor 8,6: para nós, contudo existe um só Deus, o Pai, de quem tudo procede (...) ; cf. 1Cor 11,12; Ef 3,9; Cl 1,16) ${ }^{115}$, como "Rei e Juiz" (Rm 2,16: "no dia em Deus, segundo o meu evangelho, julgará, por Cristo Jesus (...)” ; 1Cor 15,24-28:

114 D. GUTHRIE; R.P. MARTIN. Dio. In: G.F. HAWTHORNE; R.P. MARTIN; D.G. REID. Dizionario di Paolo e delle sue Lettere. Cinisello Balsamo: San Paolo Edizioni, 2000, p. 445-446. 115 D. GUTHRIE; R.P. MARTIN. Dio. In: G.F. HAWTHORNE; R.P. MARTIN; D.G. REID. Dizionario di Paolo e delle sue Lettere, p. 448: Comentando sobre Deus Criador e Deus Rei e Juiz na visão paulina Guthrie e Martin afirmam: "Nelle sue lettere Paolo distanzia il Creatore dalle creature, come in Rom 1,25. Si dice, inoltre, che la creazione riflette l'opera del Creatore (Rom 1,20). Per farlo solo perché è l'opera diretta delle sue mani. Ci sono specifiche affermazione che tutte le cose sono state fatte da Dio (Rom 11,36; 1Cor 8,6; 11,12; Ef 3,9). Paolo rispecchia la stessa convinzione dell'AT che la creazione non è coeterna al Creatore e non è il prodotto di una divinità inferiore, come poi nello gnosticismo. Dio è l'autore di tutto ciò che esiste, benché a Paolo interessi sopratutto l'elezione divina espressione 'prima della fondazione del mondo', indicando così che il Creatore esisteva indipendentemente dall'esistenza materiale della creazione”. 
“A seguir haverá o fim, quando ele entregar o reino a Deus Pai (...) Pois é preciso que ele reine ..." $)^{116}$ etc.

\subsection{O ESPÍRITO E O GRITO A $\beta \beta \dot{\alpha}$ - PAI}

4.2.1 v. $15 \mathrm{a} \alpha-15 \mathrm{c} \gamma$

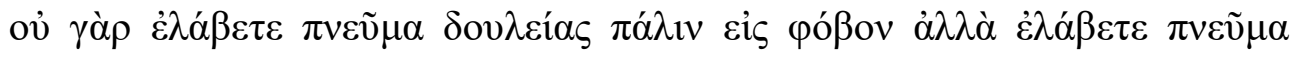

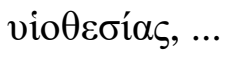

De fato, vós não recebestes um espírito de escravidão, novamente para o medo, mas vós recebestes um Espírito de Filiação, ...

Lexicalmente, a partícula ov̉ aparece 1612x no NT e quer dizer "não". Esta partícula negativa pode ser usada como negação objetiva e como exclamação. $\mathrm{O}$ NT sublinha o aspecto decisivo de "não", como expressão de uma convicção e como clara manifestação da fé fit $^{11}$.

Paulo funda sua determinação dogmática deste modo: Jesus Cristo encarna o total sim de Deus ao mundo, à história e à humanidade. Deus, na encarnação do seu Filho pronunciou "um sim de princípio" ao mundo e a cada homem. Desta fé nasce a determinação também do não e da confiança que a autoridade apostólica deseja à comunidade ${ }^{118}$.

\footnotetext{
116 D. GUTHRIE; R.P. MARTIN. Dio. In: G.F. HAWTHORNE; R.P. MARTIN; D.G. REID. Dizionario di Paolo e delle sue Lettere, p. 452-453: Sobre a realeza de Deus e sua autoridade de Juiz eles comentam: "L'idea di regalità deriva dalla potenza creatrice di Dio. Quando pregavano, i primi cristiani lo risconoscevano, rivolgendosi a Dio come 'Signore sovrano, che hai fatto il cielo e la terra e il mare e tutto ciò che è in essi' (At 4,24). Egli che crea ha il diritto di ordinare, mentre la creatura non ha il diritto di contestare le decisioni del Creatore. La sovranità di Dio è inerente all'attività creatrice di Dio. Paolo vede l'atto finale della storia con la sottomissione - da parte di Dio - di tutti i nemici 'sotto i suoi piedi' (Rom 16,20; 1Cor 15,23-28). Nel pensiero dell'apostolo c'è una piccola reale distinzione tra il regno di Dio e il regno di Cristo, se Cristo alla parusia consegnerà il suo regno a Dio (1Cor 15,24), trasformando così il regnum Christi in regnum Dei. Ciò che è centrale per il pensiero di Paolo, in questo contesto, è la suprema sovranità di Dio su ogni cosa. Il concetto di re è strettamente collegato a quello di giudice. Per Paolo l'ideia di Dio come giudice era parte integrante del suo vangelo (Rom 2,16); non dubitava, infatti, che Dio avrebbe giudicato il mondo (Rom 3,6). Parla con sicurezza del 'tribunale di Cristo' (2Cor 5,10). Per fine, è considerato giusto e conveniente in Paolo che il re divino eserciti la sua prerogativa di giudizio. Però è importante vedere i giudizi di Dio attraverso il prisma della cristologia di Paolo".

117 P.G. MÜLLER. ov̉. In: H. BALZ; G. SCHNEIDER. Dizionario Esegetico del NT. Brescia: Paideia Editrice, 2004, p. 667-669.

${ }^{118}$ P.G. MÜLLER. ov̉. In: H. BALZ; G. SCHNEIDER. Dizionario Esegetico del NT, p. 669.
} 
No nosso texto, o advérbio de negação oủ vem como antítese da apresentação dos dois tipos de espíritos, que representam os dois estados de vida: o da morte, caracterizado pela escravidão, e o da vida, caracterizado pela filiação adotiva.

O início do v.15, introduzido por " $\gamma \alpha ́ \rho$ / de fato" confirma e explica tudo aquilo que foi dito no versículo precedente.

Segundo Pitta ${ }^{119}$, a relação entre Espírito e filiação divina é demonstrada por Paulo com a utilização da voz verbal غ่̇ $\alpha \beta \varepsilon \tau \varepsilon: 2^{a}$ pessoa plural do verbo $\lambda \alpha \mu \beta \alpha ́ v \omega$, que invoca a origem divina do Espírito, significando que foi enviado por Deus (Gl 4,6) e que está em continuidade com o envio de Jesus, seu Filho único.

O seu ambiente semântico é antes de tudo "tocar, pegar", em sentido pacífico ou violento. Podemos também encontrar este termo aplicado a um estado de ânimo, à situação de doença e como um acolhimento espiritual.

$\mathrm{Na}$ LXX, $\lambda \alpha \mu \beta \alpha ́ v \omega$ dá a mesma ideia da raiz hebraica ç̣ como também $\delta \varepsilon ́ \chi 0 \mu \alpha \imath$ que semanticamente é "acolher e receber". Do amplo campo de significado e do uso em partes não específicas emergem dois dados fundamentais: o aspecto do movimento e da tensão exprime-se mais forte no "pegar e levar", já a parte não tanto ativa exprime-se no "receber e acolher" 120 . O verbo $\lambda \alpha \mu \beta \alpha ́ v \omega$ aparece 260x no NT e significa "pegar", "receber", "tocar", “alcançar", "acolher" e "aferrar"

Kretzer $^{122}$ diz que a multiplicidade de uso no NT do verbo $\lambda \alpha \mu \beta \alpha ́ v \omega$, a exemplo de Paulo e dos Evangelhos confirma a vasta tensão e amplo significado do verbo. Não obstante, o mesmo encontra-se concentrado em "receber e acolher" onde faz prevalecer a dimensão teológica significativa. Assim sendo, torna-nos claro o porquê do NT, insistir em apresentar a relação do homem com Deus como uma relação de um que recebe e um que doa.

Légasse $^{123}$ faz uma observação que parece importante tê-la em consideração para sanar as dúvidas sobre a origem do Espírito. A questão é que no v.15 a palavra

119 A. PITTA. Lettera ai Romani: Nuova versione, introduzione e commento, p. 294; U. WILCKENS. La carta a los Romanos 6-16 (II), p. 169: "Somos hijos de Dios; esto significa que hemos comenzado a serlo al recebir en el bautismo el Pneuma como Espíritu de Filiación".

${ }^{120}$ A. KRETZER. $\lambda \alpha \mu \beta \alpha ́ v \omega$. In: H. BALZ; G. SCHNEIDER. Dizionario Esegetico del NT. Brescia: Paideia Editrice, 2004, p. 148-149.

${ }^{121}$ A. KRETZER. $\lambda \alpha \mu \beta \alpha ́ v \omega$. In: H. BALZ; G. SCHNEIDER. Dizionario Esegetico del NT. Brescia: Paideia Editrice, 2004, p. 148.

${ }^{122}$ A. KRETZER. $\lambda \alpha \mu \beta \alpha ́ v \omega$. In: H. BALZ; G. SCHNEIDER. Dizionario Esegetico del NT, p. 152. ${ }^{123}$ S. LÉGASSE. L'Épître de Paul aux Romains, p. 505: 'L'expression 'esprit d'esclavage' s'aligne

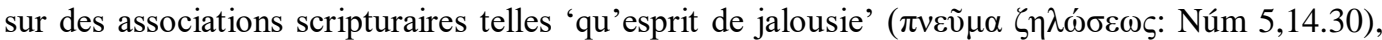

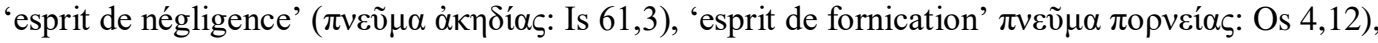

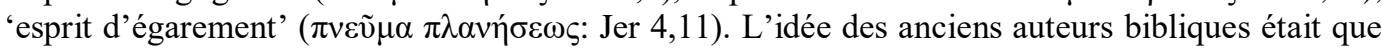


$\pi v \varepsilon \tilde{v} \mu \alpha$ vem citada duas vezes de modo contrastante regida pelo mesmo verbo, gerando a pergunta: Aqui se trata verdadeiramente do Espírito de Deus? De fato, $\pi v \varepsilon \tilde{v} \mu \alpha$ sendo regido pelo mesmo verbo nos permite intuir que os dois espíritos são da mesma natureza, contudo, como o Espírito de Deus não pode gerar a escravidão no homem em sentido negativo, a reflexão nos leva a crer, que a incidência do versículo está na resposta ${ }^{124}$ dada na adesão à vida nova recebida de Deus por intermédio do seu Espírito, que é o Espírito de Jesus, seu Filho único.

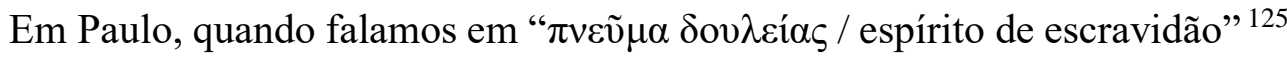
entendemos não somente o sentido negativo que a palavra supõe, mas sobretudo a dimensão de doação total ao serviço de Deus. Para termos uma melhor noção do termo observemos como vêm interpretadas as palavras de raiz $\delta$ ov $\lambda$-. Elas aparecem complexivamente no NT 182x e podem significar: " $\delta o v \lambda \varepsilon v ́ \omega /$ cumprir o serviço de

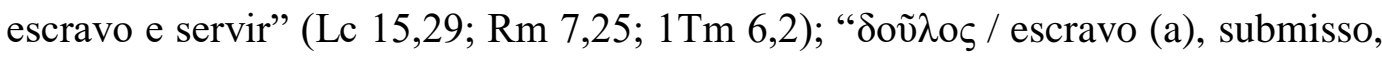

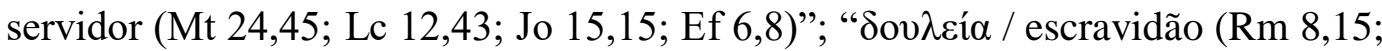

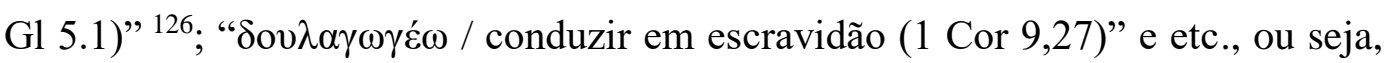
esta raiz põe sempre o acento "no servir como escravo", e então num serviço tido como dependência de um homem totalmente vinculado a um superior ${ }^{127}$.

No AT e no judaísmo antigo ${ }^{128}$ Deus é o Senhor Absoluto. Aqui o homem é totalmente dependente de Deus e ser escolhido por Deus para servi-lo não é degradante, mas honroso. Para o dualismo gnóstico ${ }^{129}$ as palavras derivadas desta raiz servem para exprimir o serviço à matéria e às potências do mundo. Por sua vez, no NT as palavras desta raiz, servem para indicar relacionamento de dependência e de serviço nos seguintes meios ${ }^{130}$ :

rien n'échappant à l'action de Dieu, ces dispositions humaines dérivent en définitive de lui. Il en va de même dans le dualisme qumranien où les 'deux esprits', l'un de 'vérité' et l'autre de 'perversion', relèvent d'un dessein de Dieu sur chaque être humain (1QS 3,18-19)".

${ }^{124}$ J. KREMER. $\pi v \varepsilon \tilde{v} \mu \alpha$. In: H. BALZ; G. SCHNEIDER. Dizionario Esegetico del NT, p. 1012; Em Kremer vemos a diversidade dos significados do uso de $\pi v \varepsilon \tilde{u} \mu \alpha$.

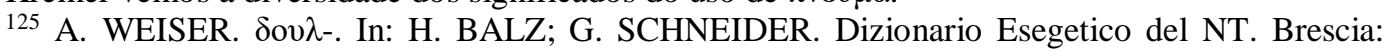

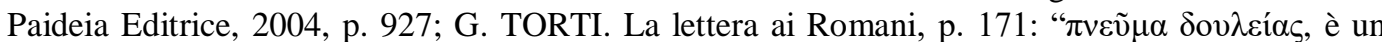

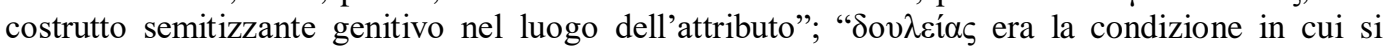
trovavano i cristiani prima del riscatto".

${ }^{126}$ A.A. RUPPRECHT. Schiavo, schiavitù. In: G.F. HAWTHORNE; R.P. MARTIN; D.G. REID. Dizionario di Paolo e delle sue Lettere. Cinisello Balsamo: San Paolo Edizioni, 2000, p. 1416-1419.

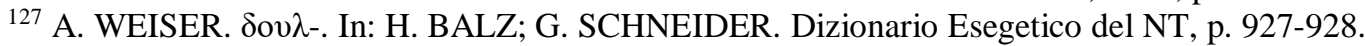

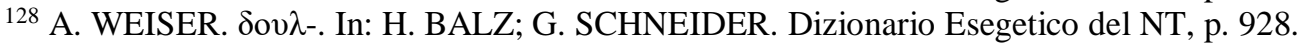

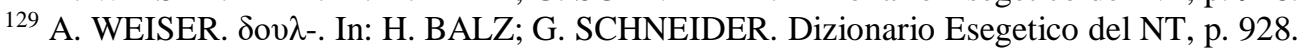

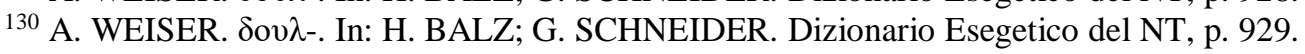


- no estado de escravidão, como uma condição social: escravo doméstico (Mt 8,9); com relação ao um filho (Gl 4,1); escravo livre (1Cor 12,13); escravo amigo (Jo 15,15);

- no relacionamento de dependência e de serviço do homem para com Deus que é Senhor absoluto (Ef 6,7,1Pd 2,16);

Significativos são os escritos paulinos que apresentam esta raiz em diversos contextos com os seguintes significados ${ }^{131}$ :

- os cristãos através do batismo são libertados das potências escravizantes do pecado, da lei, da morte, do cosmo e livres para serem filhos;

- o fato de serem filhos significa que estão a serviço de Deus, de Cristo, da justiça, do próximo na "nova realidade do Espírito" $(\mathrm{Rm} 7,6)$ e não de uma liberdade autônoma e dissoluta;

- para Deus a vida do escravo têm o mesmo valor que a vida de quem é livre, pois cada um têm as mesmas responsabilidades diante de Deus;

- Paulo chama a si mesmo e a seus colaboradores de servos de Cristo ou de Deus;

- no hino pré-paulino de Filipenses diz-se de Jesus Cristo: "Ele tinha a condição divina, e não considerou o ser igual a Deus como algo a que se apegar ciosamente. Mas esvaziou-se a si mesmo, e assumiu a condição de servo" (Fl 2,6-7).

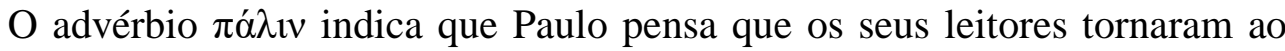
regime que tinham abandonado, isto é, retorno à impotência ou à $\alpha \kappa \rho \alpha \sigma i ́ \alpha^{132}$ "intemperança" (Mt 23,25; 1Cor 7,5), na qual os homens encontravam-se na condição de escravos (Rm 7,7-25) antes da ação libertadora do Espírito. O termo $\pi \alpha ́ \lambda ı v$ aparece 141x no NT e pode significar: "novamente", "atrás", "ainda”, "de novo" e "da outra parte".

O regime de escravidão levaria os homens à " $\varphi$ ó $\alpha$ / medo". Schlier ${ }^{133}$

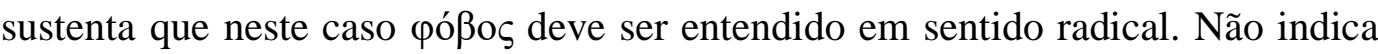

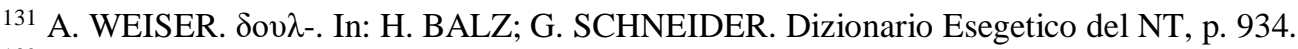

${ }^{132}$ A. PITTA. Lettera ai Romani: Nuova versione, introduzione e commento, p. 296.

${ }^{133}$ H. SCHLIER. La Lettera ai Romani, p. 417-418.
} 
uma realidade particular na qual se tem medo, nem sequer um respeito e reverência

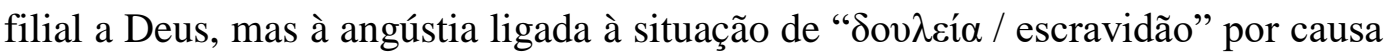
da situação da lei, do pecado e da morte que Paulo descreveu nos capítulos 6 e 7 da Carta aos Romanos ${ }^{134}$.

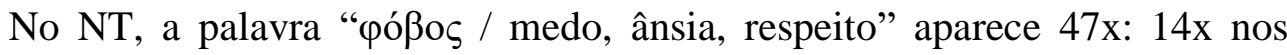
Evangelhos, 5x nos Atos dos Apóstolos, 12x nos escritos paulinos e 16x nos escritos não paulinos (1Pd, 1Jo e Ap) ${ }^{135}$. Assim como o verbo que significa "temer", aparece também o substantivo que colhe o mesmo significado, conforme o contexto, como $^{136}$ :

Terror (pânico); de temor luminoso diante de um evento incompreensível; de temor como comportamento fundamental diante de Deus e nos relacionamentos de submissão desejada por Deus no sentido de respeito; e por fim, de medo diante uma ameaça e de uma punição.

O temor pode, de um lado, ser visto como potência autônoma que "غ̇ंı

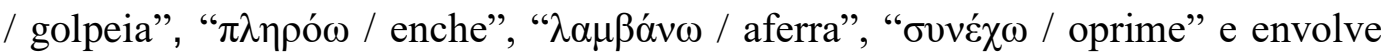
homens; já, por outro lado, constitui uma íntima reação ou emoção, ao qual segue um determinado agir e evento. Somente o Evangelho de João usa póßos exclusivamente em sentido teológico não específico, para designar o temor que os seguidores ou os discípulos de Jesus tinham dos Judeus ${ }^{137}$.

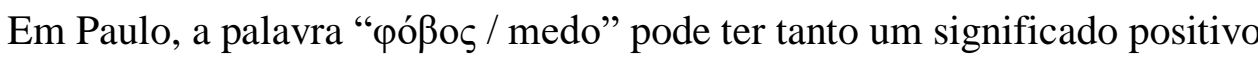
como negativo. Assim, retomando uma tradição antigo-testamentária-judaica, ele afirma que os homens sem temor de Deus estão sob a potência do pecado. Por isso

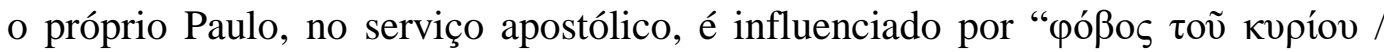
temor do Senhor", ou seja, é envolvido, tomado e ao mesmo tempo estimulado a ter confiança ${ }^{138}$.

Ao contrário do que propõe o espírito de escravidão, Paulo, com superlativa beleza, indica, no v.15, que recebemos o Espírito de adoção ${ }^{139}$, que nos une a Cristo

\footnotetext{
${ }^{134}$ R. PENNA. Lettera ai Romani: Rm 6-11 (II), p. 163. De fato, o advérbio "novamente" indica que o medo pertence a razões do passado.

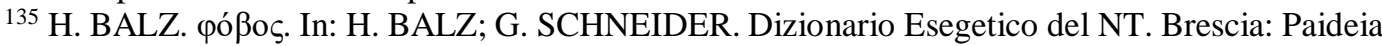
Editrice, 2004, p. 1814-1815.

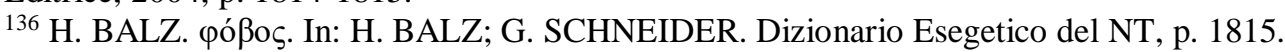

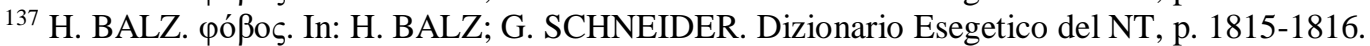

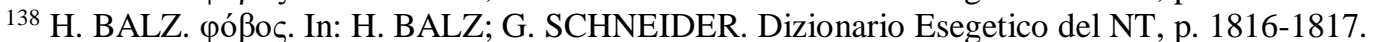

${ }^{139}$ R. PENNA. Non uno spirito da schiavi per ricadere nella paura $(\mathrm{Rm} 8,15)$. PSV: quaderni di lettura bíblica 33 - La paura. Bologna: EDB, 1996, p. 148.
} 
possibilitando crer nele e assim tornando-nos partícipes da sua filiação (Mt 5,9; 6,9; Lc 6,35; 20,36; Jo 1,12; 3,3.5; Rm 6,4; 8,14-17.29; 9,4; Gl 3,26; 4,5ss.; Ef 1,5; Tt 3,5; Hb 12,5-12; $1 \mathrm{Pe} 1,3 ; 2,2 ; 2 \mathrm{Pe} 1,4 ; 1$ Jo 3,1-2). O vocábulo grego que manifesta esta filiação ${ }^{140}$ é vio $\theta \varepsilon \sigma i ́ \alpha$. No mundo grego o termo significa aceitação como filho e não existe fonte de ocorrência deste vocábulo antes do séc. II a.C.

$\mathrm{Na}$ Grécia antiga ${ }^{141}$ nem sempre a adoção era ligada a uma rígida formalidade. Por exemplo, no direito da cidade cretense de Gortina a adoção devia ser feita no mercado, na presença de um grupo de cidadãos da alta tribuna do orador. Um particular é que as normas consentiam a adoção também da parte de quem tinha descendentes masculinos. Em Atenas a " $\pi$ oínбıৎ/ adoção" parece prevista somente em caso de falta dos descendentes e é permitido somente a adoção de cidadãos áticos de legítima descendência ${ }^{142}$.

Na LXX não encontramos o conceito de adoção. No NT, o vocábulo vem usado unicamente para indicar a assunção a filho de Deus em Paulo. A indicação do termo como filiação é entendida não como um fato natural, mas como uma superlativa grandeza do dom de Deus que nós devemos sempre agradecer por tal gratuidade que recebemos somente pela fé. Conforme Fitzmyer ${ }^{143}$, Paulo aplica o

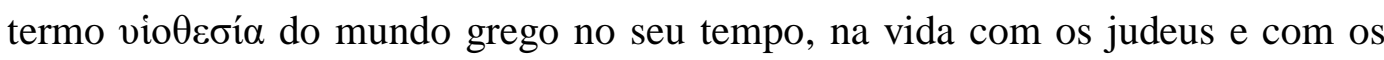
cristãos:

140 X. LÉON-DUFOUR. Hijo de Dios. Barcelona: Herder, 1965, 1966, p. 386-387: "En los sinópticos se afirma repetidas veces la filiación adoptiva de que hablava ya el AT: Jesús no sólo enseña a los suyos a llamar a Dios de 'Padre nuestro' sino que da el título de 'hijos de Dios' a los pacíficos, a los caritativos, a los justos resucitados. La doctrina de los escritos joánicos tiene exactamente el mismo tono. Hay que renacer, dice Jesús a Nicodemos del agua y del Espíritu. Es que, en efecto, a los que creen en Cristo les da Dios poder de venir a ser hijos de Dios. Esta vida de hijos de Dios es para nosostros una realidad actual, aun cuando el mundo lo ignore. Vendrá un día en que se manisfestará abiertamente y entonces seremos semejantes a Dios porque lo veremos tal como es. No se trata, pues, ya únicamente de un título que muestra el amor de Dios a sus criaturas: el hombre participa de la naturaleza de aquel que lo ha adoptado por hijo"; S.P. Millos. Romanos: Comentario Exegético al Texto Griego del NT. Barcelona: Editorial Clie, 2011, p. 623.

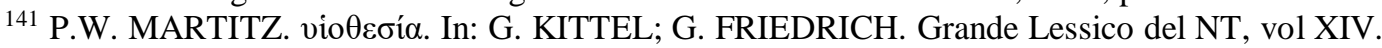
Brescia: Paideia Editrice, 1984, p. 269.

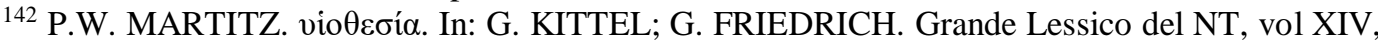
p. 269.

143 J.A. FITZMYER. La Lettera ai Romani: Commentario critico-teologico, p. 596: Falando teologicamente sobre a filiação adotiva Fitzmyer utilizando também uma ajuda de Michel diz: "Per

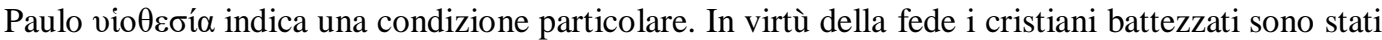
assunti nella famiglia di Dio, sono entrati sotto la patria potestas di Dio stesso ed hanno acquisito una condizione di figli legittimi in questa famiglia; non semplecimente la condizione di schiavi (che pure dell'antica famiglia erano integrante), ma quella di figli. La filiazione adottiva è espressione della libertà del battezzato, il quale non deve riconoscere altro legame che non sia volontà di Dio, nella convinzione che Dio si è dato all'uomo e nella fiducia che scaturisce dal suo essere Padre. L'atteggiamento dei cristiani, quindi, dovrebbe corrispondere alla condizione di cui godono". 
Em Rm 9,14 Paulo usa o termo em relação a Israel, no sentido amplo, para indicar a filiação global e corporativa do povo escolhido. Normalmente, no AT não se fala de adoção. Os únicos textos que parecem tocar na perspectiva de adoção são Gn 15,2; 48,$5 ; \operatorname{Jr} 3,19$ e $1 \mathrm{Cr} 28,6$. No posterior Judaísmo rabínico fala-se de homens que tomam conta de filhos de outros pais, porém não existe uma certeza se a esses filhos venham reconhecidos todos os direitos legais que possui os verdadeiros filhos.

Para Wilckens ${ }^{144}$ a filiação era apresentada para os israelitas na cultura veterotestamentária judia com a proposição "vioì $\theta \varepsilon$ oṽ / filhos de Deus", e com Cristo a filiação se extende para todos cristãos (provindos do judaísmo e

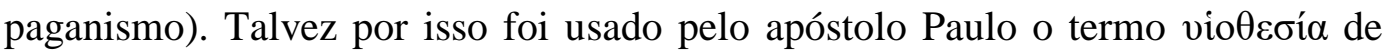
origem helenística dando a possibilidade de abertura a outros povos para serem filhos adotivos de Deus, por intermédio do batismo.

O texto de Rm 8,19 mostra que a espera escatológica tem um papel essencial,

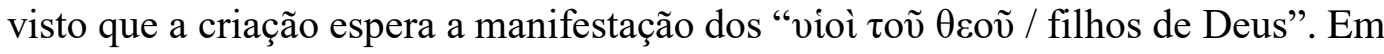
Rm 8,23, fala-se de vio $\theta \varepsilon \sigma i ́ \alpha$ no sentido da redenção do corpo. Não obstante estas citações, vale ressaltar que para Paulo a filiação não é um bem salvífico exclusivamente do futuro, mas um bem presente como encontramos em Rm 8,14:

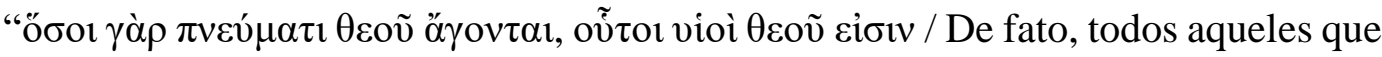
são conduzidos pelo Espírito de Deus, esses são filhos de Deus"145. Os crentes receberam o "Espírito de filiação" e, por isso, podem gritar: 'A $\beta \beta \alpha ́$ Pai $(\mathrm{Rm} 8,15)$. Com isto, o Espírito confirma que nós somos " $\tau \varepsilon ́ \kappa v \alpha \theta \varepsilon$ coṽ / filhos de Deus" e, como

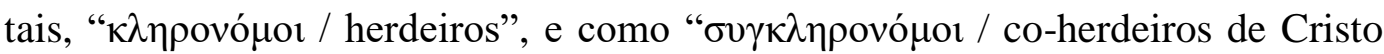
vamos ao encontro da glória futura ( $\mathrm{Rm} 8,16 \mathrm{ss})$.

\section{2 .2 v. $15 \mathrm{~d} \alpha-15 \mathrm{e} \beta$}

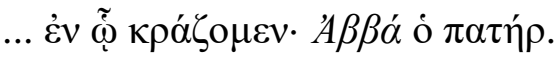

... no qual gritamos: Abba Pai!

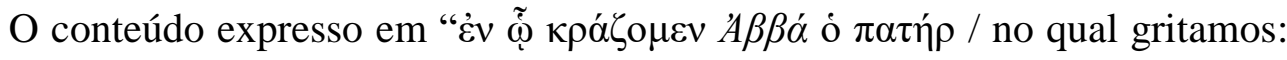
Abba Pai" é a consequência da vida no Espírito ${ }^{146}$, tanto que Paulo utiliza um verbo

\footnotetext{
${ }^{144}$ U. WILCKENS. La carta a los Romanos 6-16 (II), p. 170.

${ }^{145}$ P. ALTHAUS. La Lettera ai Romani. Brescia: Paideia Editrice, 1970, p. 165: "Nell'essere figli si raccogli tutta dignità e la vera salvezza dei credenti. La certezza di essere figli coincide con la certezza di essere salvi. Tutto dipende della certezza della nostra adozione".

${ }^{146}$ MAZZAROLO, I. A Carta aos Romanos: Educar para a maturidade e o amor. Rio de Janeiro: Mazzarolo editor, 2006, p. 103.
} 
que implica uma participação intensa do sujeito que a exprime. Esta familiaridade nos deu o Espírito de Deus que vive dentro de cada cristão, permitindo realizar este apelo em direção ao Eterno Pai.

Relacionando o texto de Gálatas com o de Romanos, observamos duas realidades: na primeira, confirmamos que de fato Paulo, na Carta aos Romanos, desenvolve a explanação sobre o relacionamento do Espírito com o homem da carta aos Gálatas; e na segunda, encontramos uma reciprocidade ${ }^{147}$ entre o Espírito e o homem.

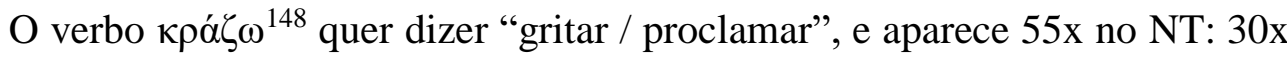
nos Evangelhos, 11x nos Atos dos Apóstolos, 2x nos Escritos paulinos (Rm 8,15; Gl 4,6), 1x em Tg 5,4 e 11x no Apocalipse. Este verbo normalmente em sentido pleonástico indica um gritar vazio e incompreensivo (Mt 14,26; 27,50; Mc 5,5.7; 9,26; 15,39; Lc 9,39; At 7,57.60; Gl 4,16; Ap 10,3; 12,2), entretanto, junto com o verbo " $\lambda \varepsilon ́ \gamma \omega$ / dizer" introduz um enunciado (Mt 8,29; 9,27; 15,22; 20,30-31; 21,9.15; 27,23; Mc 3,11; 5,7; 10,47-48; 11,9; 15,13-14; Lc 4,41; 18,39; Jo 12,13) ou uma declaração que Jesus faz de si mesmo (Jo 7,28.37.40; 12,44).

Segundo Fendrich ${ }^{149}$, Rm 8,15 e Gl 4,6 afirmam que o Espírito de filiação faz o crente gritar " $A \beta \beta \alpha ́$ Pai”" ${ }^{50}$. No ponto de vista de Käsemann ${ }^{151}$ Paulo faz alusão a uma situação cultual. O grito $A \beta \beta \alpha^{152}$ da comunidade é inspirado pelo " $\pi v \varepsilon v \tilde{\mu} \alpha$ /

\footnotetext{
${ }^{147}$ A. PITTA. Lettera ai Romani: Nuova versione, introduzione e commento, p. 297: Com relação a esta última observação Pitta recorda: "Dal confronto con Gál 4,6 risalta subito il cambiamento del processo nella relazione tra lo Spirito e il grido: ora, non è più lo Spirito che grida in noi ma noi gridiamo nello Spirito. A causa della partecipazione con Cristo e con lo Spirito, entrambi i movimenti sono significativi: lo Spirito grida in noi perchè è in noi, quale presenza permanente di Cristo; gridiamo nello Spirito perchè siamo nello Spirito (Rom 8,9), come siamo in Cristo. Il cambiamento del movimento è dovuto proprio all'accentuazione dell'essere nello Spirito e nella relativa partecipazione, proprio di Rom 8,1-13, mentre in Gál 4,17 Paolo non aveva ancora sviluppato questo aspetto relazionale tra i credenti e lo Spirito".

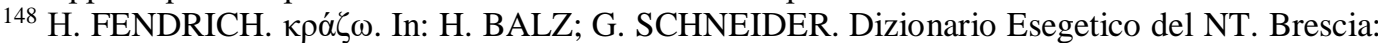
Paideia Editrice, 2004, p. 90-92.

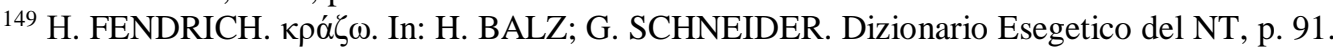

150 F.F. BRUCE. Romanos: Introdução e comentário. São Paulo: Vida Nova, 1979, p. 134; U. VANNI. Lo Spirito e la libertà secondo Paolo. PSV: quaderni di lettura bíblica 4 - lo Spirito del Signore. Bologna: EDB, 1979, p. 178.

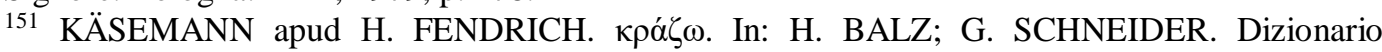
Esegetico del NT, p. 91.

${ }^{152}$ LUTERO apud F.F. BRUCE. Romanos: Introdução e comentário, p. 135: "Esta é uma palavra tão pequenina, e, no entanto, abrange todas as coisas. A boca não fala assim, mas o afeto do coração fala desse modo. Ainda que eu seja oprimido pela angústia e terror de todo lado, e pareça estar abandonado e ter sido totalmente expulso da Tua presença, contudo sou Teu filho, e Tu és meu Pai, por amor de Cristo: sou amado por causa do Amado. Por conseguinte, esta pequena palavra Pai, concebida efetivamente no coração, sobrepuja toda eloquência de Demóstenes, de Cícero, e dos mais eloquentes retóricos que já houve no mundo. Esta matéria não se expressa com palavras, mas com
} 
espírito" que torna possível a relação de filiação e motiva todo aquele que crer a confessar a sua fé no Cristo, mestre e Senhor que pela sua Morte e Ressureição redimiu toda a humanidade.

Para Torti ${ }^{153}$ o significado preciso do verbo no presente contexto é discutível. Entretanto, Althaus assegura que para Kuss o verbo vai do forte grito estático isolado à "oração em alta voz com tom de confiança e alegria, contrapondo-se, segundo Paulo, à oração dos judeus que, por tradição, devia ser murmurada, isto é, sinal do espírito de quem é servo" ${ }^{154}$.

No aramaico antigo $A \beta \beta \alpha ́$ é um vocábulo próprio da linguagem infantil ${ }^{155}$ que significa "papai". Mas na época neotestamentária o uso não era mais limitado à linguagem das crianças ${ }^{156}$, dado que também era usado pelos filhos adultos e servos quando se direcionavam aos anciãos. Deste modo, em hebraico esta palavra recebe a conotação não somente de "meu Pai", mas de "seu Pai e nosso Pai"157.

Na literatura proto-cristã, $A \beta \beta \alpha ́$ aparece 2x em Paulo (Gl 4,6 e Rm 8,15) e 1x no Evangelho de Marcos (Mc 14,36) como termo usado para direcionar-se a Deus. No Judaísmo antigo não se encontra $A \beta \beta \alpha ́$ como termo pelo qual nos direcionamos a Deus, mesmo se a invocação coletiva Pai-Nosso foi testemunhada em duas orações judaicas $^{158}$. Com relação às Cartas de Paulo Kittel afirma ${ }^{159}$ :

O uso do termo aramaico nas cartas de Paulo escritas em grego, pode ter sido originado de umas reminiscências litúrgicas ou talvez repete o início do Pai-Nosso. Destarte, é certo que o uso da palavra na Igreja Primitiva se restabelece na definição de Deus dada por Jesus e indica a adesão ao novo relacionamento entre Deus e o homem pregado e vivido por Cristo. O confronto do mesmo termo com o uso judaico

gemidos, gemidos que não podem ser proferidos com palavras ou com oratória, pois nenhuma língua os pode expressar".

${ }^{153}$ G. TORTI. La Lettera ai Romani, p. 172.

${ }^{154}$ KUSS apud P. ALTHAUS. La Lettera ai Romani, p. 167; C. PERROT. Epístola aos Romanos, p. 69: Conforme Perrot a oração aqui "não é simplesmente uma palavra, mas é de verdade um ato. É o próprio Deus que, através do seu espírito, provoca essa ação. Oração não é mais uma magia para extorquir o impossível, é um dom de Deus".

155 G. TORTI. La Lettera ai Romani, p. 172: "In originale l'aramaico 'abb' era una forma senza flessione del linguaggio infantile; in secondo tempo essa ha soppiantato il vocabolo 'abî e ha sostituito lo 'stato enfatico' $a b^{1}$ ' ('il padre') passando poi a significare suo padre e nostro padre"; $H$. W. KUHN. 'A $\beta \beta \alpha \dot{\alpha}$ In: H. BALZ; G. SCHNEIDER. Dizionario Esegetico del NT. Brescia: Paideia Editrice, 2004, p. 1.

${ }^{156}$ R. PENNA. I Ritratti originali di Gesù il Cristo: Inizi e sviluppi della cristologia neotestamentaria, I, p. 116; H. W. KUHN. A $\beta \beta \alpha ́$. In: H. BALZ; G. SCHNEIDER. Dizionario Esegetico del NT, p. 2; W. HENDRIKSEN. Comentário do Novo Testamento - Romanos, p. 328.

${ }^{157}$ H.W. KUHN. Á $\beta \beta \alpha ́$. In: H. BALZ; G. SCHNEIDER. Dizionario Esegetico del NT, p. 2.

${ }^{158}$ H.W. KUHN. Á $\beta \beta \alpha ́$. In: H. BALZ; G. SCHNEIDER. Dizionario Esegetico del NT, p. 2.

${ }^{159}$ G. KITTEL. A $\beta \beta \alpha ́$. In: G. KITTEL; G. FRIEDRICH. Grande Lessico del NT, vol. I. Brescia: Paideia Editrice. 1965, p. 18; confira igualmente J. JEREMIAS. A $\beta \beta \alpha ́$. Supplmenti al Grande Lessico del NT. Brescia: Paideia Editrice, 1968, p. 56-57. 
mostra como o conceito cristão de filiação entre o homem e Deus é mais íntimo que todas as concepções judaicas em mérito, também porque se apresenta como realidade absolutamente nova.

Dentro da teologia paulina, a concepção de Deus que mais se salienta é a de Deus como Pai. Na literatura paulina, a paternidade de Deus é vista em três modos: é o Pai de Jesus (1Cor 1,9); é o Pai dos cristãos (2Cor 1,2) e é o Pai de toda a criação. Podemos encontrar tantas citações, seja nas saudações iniciais das cartas de Paulo, onde ele sempre descreve Deus como Pai (Rm 1,7; 1Cor 1,3; Fl 1,2), seja quando relaciona com Jesus (2Cor 1,3; Ef 1,3; Cl 1,3) e também quando fala da glória (Gl 1,5; Ef 1,6; Fl 1,11) $)^{160}$.

Para Paulo, a paternidade de Deus significa, para aquele que crer, a fonte da vida espiritual e a certeza do seu Amor: Deus que se preocupa pelo bem do homem e pelo seu crescimento conforme o seu Amor e sua santidade. Pitta afirma "que, por causa da participação no Espírito como expressão eclesial daquela em Cristo, os crentes passam a ser em pleno título filhos de Deus, com tudo aquilo que tal relação determina e em vista da herança que herdam os filhos" ${ }^{161}$.

\subsection{O TESTEMUNHO JUNTO A NOSSO ESPÍRITO \\ 4.3.1 v.16a $\alpha-16 \mathrm{~b} \beta$}

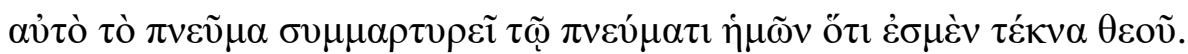

Ele, o Espírito, testemunha junto ao nosso espírito que somos filhos de Deus.

Para dar continuidade ao versículo precedente, é importante sanar o problema

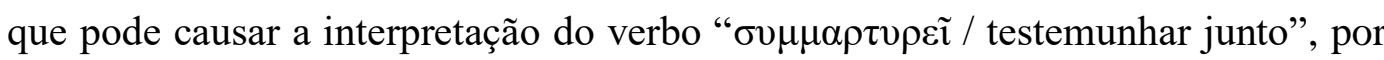
causa do prefixo $\sigma v v$-, que coloca no centro da questão o homem como independente, que sem a ajuda do Espírito, pode chegar a ser filho de Deus. Por

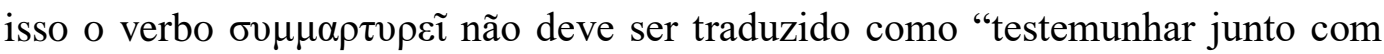
alguém", mas sim como "testemunhar alguém"162.

160 D. GUTHRIE; R.P. MARTIN. Dio. In: G.F. HAWTHORNE; R.P. MARTIN; D.G. REID. Dizionario di Paolo e delle sue Lettere, p. 450.

${ }^{161}$ A. PITTA. Lettera ai Romani: Nuova versione, introduzione e commento, p. 298.

162 J.A. FITZMYER. La Lettera ai Romani: Commentario critico-teologico, p. 597-598; H. SCHLIER. La Lettera ai Romani, p. 420; A. SACCHI. Lettera ai Romani, p. 137; A. PITTA. Lettera 
O vocábulo " $\mu \alpha ́ \rho \tau v \varsigma /$ testemunha" pertence, provavelmente, à raiz do hebraico עוֹ עוֹ, que pode significar "pensar, recordar-se, estar preocupado". Manifesta uma pessoa que recorda, e que recordando atrai conhecimento de alguma coisa e,

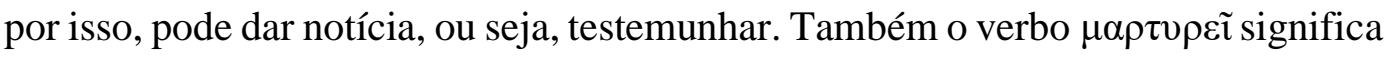
"ser testemunho, dar testemunho, testemunhar alguma coisa"163.

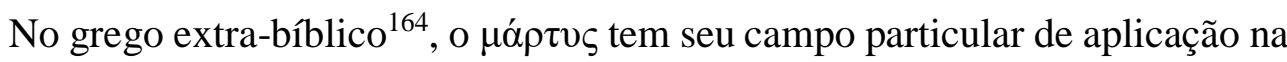
jurisprudência, e designa aquele que por experiência pessoal imediata é preparado para depor, pelo fato que tem parte direta, pois assistiu ao evento que aconteceu com a pessoa ou tem conhecimento direito da situação. $\mathrm{O}$ ato de testemunhar é

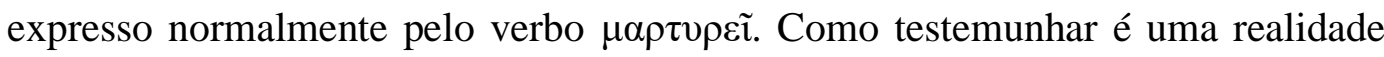
ampla, esse vocábulo pode ter, além do uso jurídico, também o uso do testemunho em modo geral, de verdade e de opinião ${ }^{165}$.

O v.16 é caracterizado pelo verbo composto " $\sigma u \mu \mu \alpha \rho \tau \nu \rho \varepsilon \tilde{~ / ~ t e s t e m u n h a r ~}$ juntos", que colocará o acento da reflexão na meditação do versículo precedente, onde o Espírito Santo, doador da vida nova dá a capacidade ao homem de adquirir

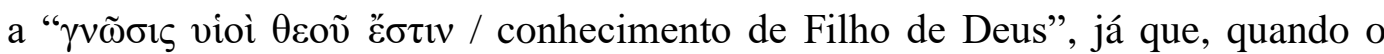
cristão, na oração ${ }^{166}$, reconhece e confessa o seu relacionamento com o Pai ele grita

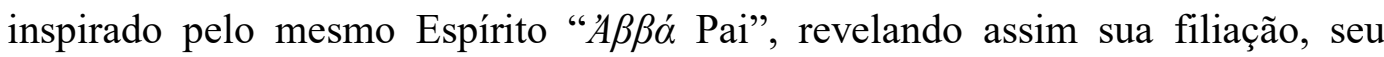
espírito é "confortado e ajudado"167 fazendo-o participante da vida de Cristo ${ }^{168}$ (Paixão, Morte e Ressurreição) e destinando-o à sua glória.

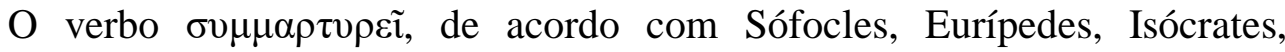
Xenofontes, Plutarco e os papiros ${ }^{169}$, é um composto de uso corrente, que aparece no NT somente em Rm 2,15; 8,16 e 9,1. O vacábulo antes de tudo como derivado de $\mu \alpha \rho \tau \nu \rho \varepsilon \tilde{i}$, significa “testemunhar juntos". Com o passar do tempo, o referimento

\footnotetext{
ai Romani: Nuova versione, introduzione e commento, p. 298-299; C.E.B. CRANFIELD. Carta aos Romanos, p. 184.

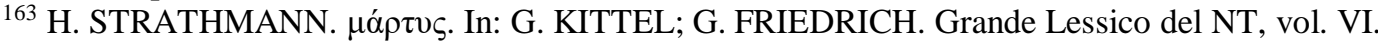
Brescia: Paideia Editrice, 1970, p. 1273-1274.

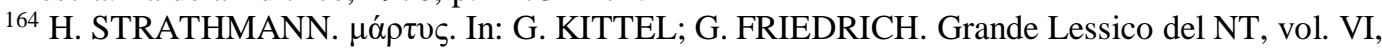
p. 1275.1277.

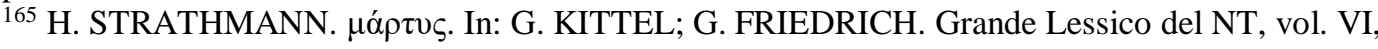
p. 1269.

${ }^{166}$ H. SCHLIER. La Lettera ai Romani, p. 420; A. SACCHI. Lettera ai Romani, p. 138.

${ }^{167}$ H. SCHLIER. La Lettera ai Romani, p. 421.

${ }^{168}$ D. ZELLER. Lettera ai Romani, p. 251: “Così, adesso, noi partecipiamo, come al suo dolore, così anche alla sua gloria. La condivisione della sofferenza è la realtà presente, ma anche il presupposto della glorificazione futura, che è di nuovo la sua meta oggettiva".

169 Sófocles; Eurípedes; Isócrates; Xenofontes; Plutarco; Papiros apud H. STRATHMANN. $\sigma v \mu \mu \alpha \rho \tau \nu \rho \varepsilon \tilde{i}$ In: G. KITTEL; G. FRIEDRICH. Grande Lessico del NT, vol. VI. Brescia: Paideia Editrice, 1970, p. 1374.
} 
ao significado fundamental se perde e $\sigma v \mu \mu \alpha \rho \tau v \rho \varepsilon \tilde{~}$ passa a significar simplesmente confirmar qualquer declaração ou afirmação de outro fato ou opinião ${ }^{170}$.

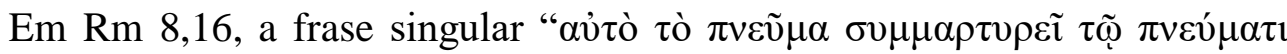

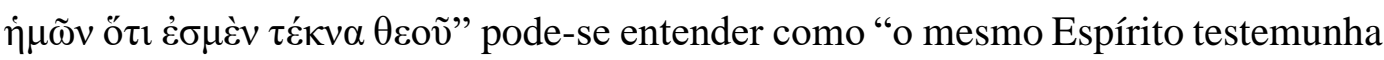
de acordo com nosso espírito que somos filhos de Deus". O divino " $\pi v \varepsilon v \tilde{\mu \alpha} /$

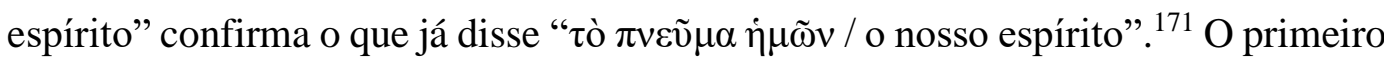

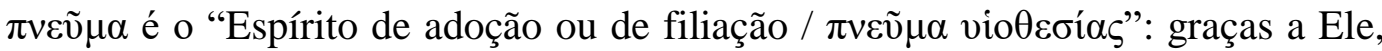
recebemos a dignidade de sermos filhos de Deus e a possibilidade de invocar Deus como Pai $(\mathrm{Rm} 8,14)$. Ao lado desse está "o nosso espírito", melhor dizendo, o nosso "eu espiritual”, o voṽ, aquele no qual chamamos alma ${ }^{172}$. Se $\sigma 0 \mu \mu \alpha \rho \tau \nu \rho \varepsilon \tilde{\imath}$ é visto em sentido estreito, pode-se dizer que aqui já existe implicitamente a afirmação no qual o "eu espiritual” proclama o cristão filho de Deus. Logo, somos obrigados a

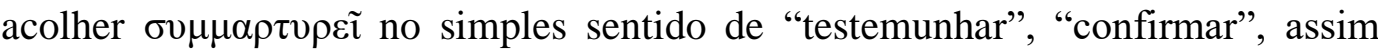
traduzindo "confirma ao nosso espírito"173.

Por fim, neste versículo o outro vocábulo fundamental e que vale ressaltar na perícope é $\tau \varepsilon ́ \kappa v o v{ }^{174}$. Este significa "criança", "menino" e "filho". Existem vários semitismos para o uso do plural $\tau \dot{\varepsilon} \kappa v \alpha^{175}$, como:

- na LXX os habitantes de uma cidade são designados como os seus $\tau \varepsilon ́ \kappa v \alpha$;

- grupos de pessoas que pertencem a uma determinada entidade vêm

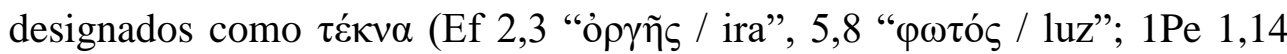

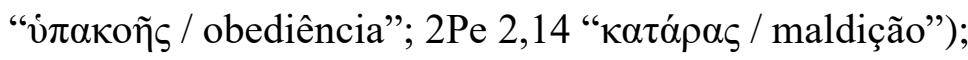

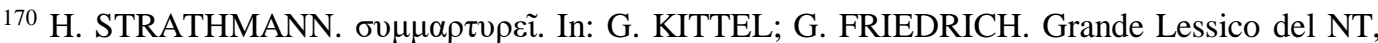
vol. VI, p. 1374

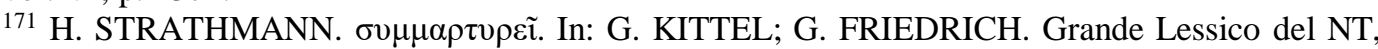
vol. VI, p. 1376.

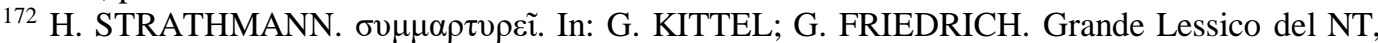
vol. VI, p. 1374.

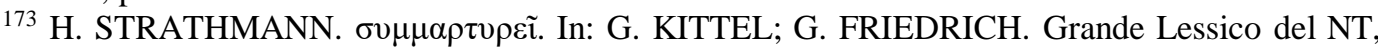
vol. VI, p. 1376-1377.

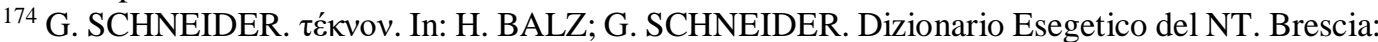
Paideia Editrice, 2004, p.1584-1585; J.A. FITZMYER. La Lettera ai Romani: Commentario criticoteologico, p. 595.

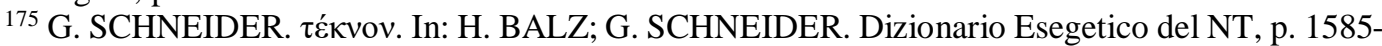
1586: "Nei passi seguenti viene usato in senso proprio: il figlio nel suo rapporto con i padre e la madre: Mt 7,11; 10,21; 15,26; 18,15; 19,29; 22,24; Mc 7,27; 10,29.30; 12,19, 13,12; Lc 1,7.17; 12,$13 ; 14,26 ; 18,19 ; 20,31 ; 23,28$; At 21,5.21; 1 Cor 7,14; 2Cor 12,14a.b; 1Tes 2,7.11; 1Tim 3,4.12; 5,4; Tt 1,6; Riguardo il battesimo del cristianesimo primitivo (1Cor 7,14); Riguardo i discendenti di una persona: Mt 2,18; 27,25; At 2,39; 13,33; Gal 4,27.31; Il rapporto con il maestro o apostolo viene designato come figliolanza spirituale: 1Cor 4,14.17; 2Cor 6,13; Gal 4,19; Flm 10,1; 1Tim 1,2; 2 Tim 2,$1 ; \mathrm{Tt} 1,4 ; 3 \mathrm{Jo}$ 4".
} 


\subsection{SOFRIMENTO E GLÓRIA}

4.4 .1 v. $17 \mathrm{a} \alpha-17 \mathrm{c} \gamma$

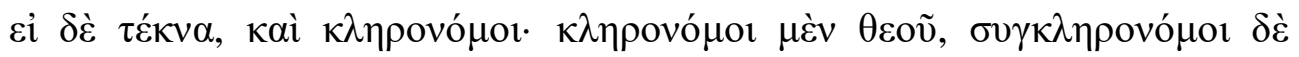

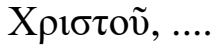

E se filhos, também herdeiros; herdeiros certamente de Deus, isto é, coherdeiros de Cristo, ...

Como para Paulo, “ $\tau \varepsilon ́ \kappa v \alpha ~ \theta \varepsilon o \tilde{v}^{176}$ / crianças de Deus” é considerado sinônimo de "vioì $\theta \varepsilon$ õ / filhos de Deus", Paulo liga a ideia da filiação divina dos cristãos com a adoção da parte de Deus como Pai ${ }^{177}$ devido ao grito pronunciado no Espírito "A $\beta \beta \alpha ́$ Pai", mostrar aos crentes que eles são "filhos de Deus", herdeiros e coherdeiros em Cristo.

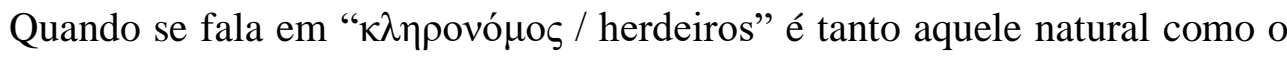
testamentário ou legal ${ }^{178}$. A partir disto é importante notar que o direito romano ${ }^{179}$ reconhecia uma ampla liberdade testamentária, pela qual o filho não era herdeiro; ao contrário, no direito grego, helenístico, judaico e do povo do Egito, o filho ou os filhos eram herdeiros eo ipso ${ }^{180}$. Outro ponto fundamental para salientar é que nos

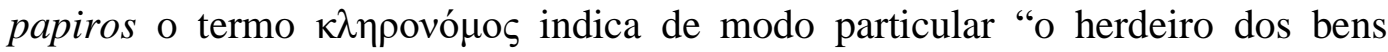
imóveis ou de um poder", enquanto jamais vem designada assim uma pessoa que receba somente bens móveis. Em outros termos, $\kappa \lambda \eta \rho o v o ́ \mu \circ \varsigma$ refere-se somente a um patrimônio real ${ }^{181}$.

O referimento à herança prometida era claro a cada ouvinte judeu, porque, já na TANAK נַחדְלָ e na LXX era incluída como a posse da terra prometida que Deus tinha concedido a Israel nos patriarcas com Abraão ${ }^{182}$ (Ex 32,13; Nm 26,52-56; Dt

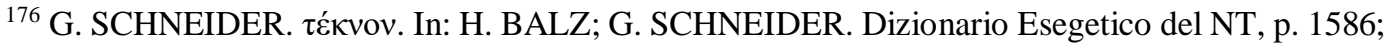
C. PERROT. Epístola aos Romanos. São Paulo: Edições Paulina, 1993, p. 68: "Paulo não distingue 'filhos' de 'crianças', diferentemente de João que reserva a palavra 'Filho' para o Cristo (Jo $1,12.18)$ ".

${ }^{177}$ R. PENNA. Lettera ai Romani: Rm 6-11 (II), p. 166.

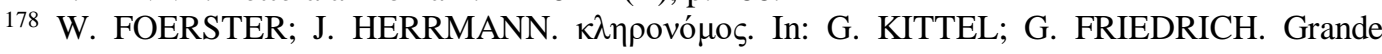
Lessico del NT, vol. V, Brescia: Paideia Editrice, 1969, p. 612.

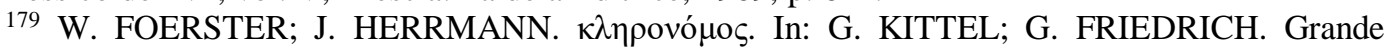
Lessico del NT, vol. V, p. 614.

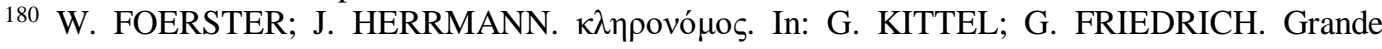
Lessico del NT, vol. V, p. 614; J.D.G. DUNN. Jesus y el Espíritu, p. 563.

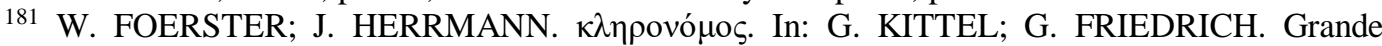
Lessico del NT, vol. V, p. 614-615.

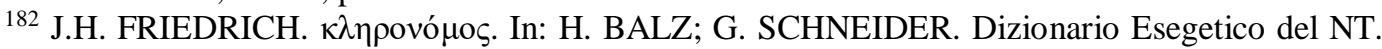
Brescia: Paideia Editrice, 2004, p.50.
} 
6,10) e que, para Paulo, essa estendia-se à sua "descendência" que estava em Cristo (Gl 3,16.18.29; 4,1.7) ${ }^{183}$, onde todos os que eram cristãos sendo herdeiros e coherdeiros em Cristo participavam da mesma graça (Ef 3,18; $\operatorname{Rm~8,17;~Gl~4,7).~}$

A este ponto parece imprescindível considerar a clareza de Cranfield $^{184}$, quando recorda que:

... nem o termo "herdeiro de Abraão, o qual há de receber no devido tempo, as bênçãos que Deus prometeu a ele e à sua descendência", nem o paradoxo envolvido ao referir-se a "herdeiros do (Eterno) Deus" deve ser eliminado apelando para o fato de que os dois verbos hebraicos, que se usavam quando se aludia à sucessão hereditária, significam, em primeiro lugar e na maioria das vezes, não "adquirir por sucessão hereditária", mas respectivamente, "possuir" e fazer com que se distribua a alguém como sua porção; porque aqui, em $\mathrm{Rm} 8,17$, existe o relacionamento mais estreito possível entre direito de herança e filiação, e a filiação em apreço é com toda clareza (v.16) a de filho de Deus. Aqui as imagens retóricas, naturalmente, deixam de funcionar; já que o Deus eterno não morre (o pensamento que está presente em Hb 9,15-17 não está presente aqui), não há problema de herdeiros de Deus sucederem-lhe. No entanto, elas apontam com eficácia mais extraordinária para os fatos de que os cristãos são homens que têm grandes expectativas; que suas expectativas fundamentam-se no fato de serem filhos de Deus; que estas expectativas referem-se à participação, não apenas em diversas bênçãos que Deus pode outorgar, mas naquilo que é peculiarmente próprio dele, a glória perfeita e imorredoura da sua própria vida; e que essa fixação do tempo em que essas expectativas serão concretizadas está fora do seu domínio.

No NT o vocábulo $\kappa \lambda \eta \rho o v o ́ \mu \rho \varsigma /$ herdeiro" aparece $15 \mathrm{x}^{185}$. Paulo aqui não

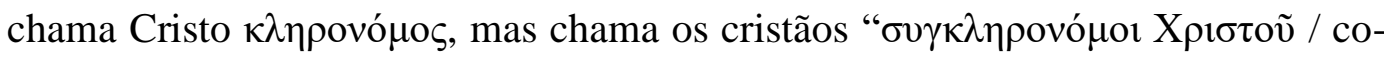
herdeiros de Cristo" $(\mathrm{Rm} 8,17)$ e liga a herança dos cristãos expressamente à sua

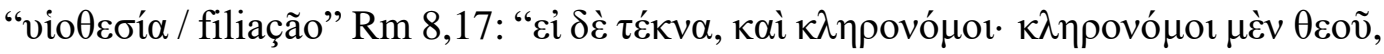

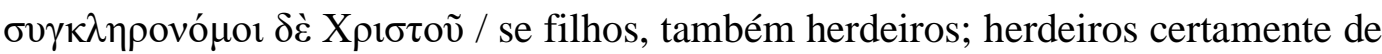

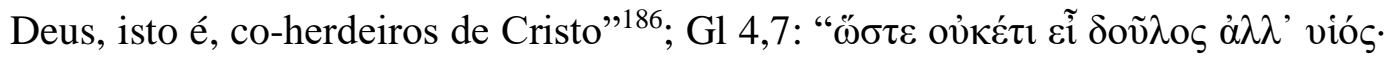

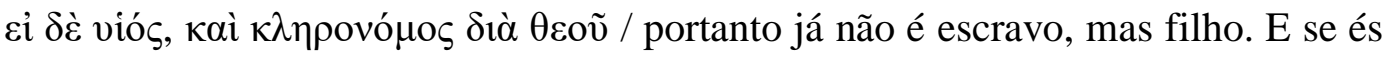

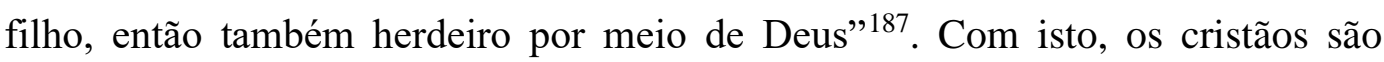

\footnotetext{
${ }^{183}$ Mesmo tendo presente a Divindade de Cristo, Filho unigênito de Deus, Jesus assume a nossa carne fazendo-se homem como nós, mas não participando conosco do pecado, entra na história da humanidade, dentro da raça eleita pelo Eterno Pai desde o início do seu projeto salvífico, desde Abraão (Gn 12), passando por Davi (1Sm 16) comprovando que Jesus historicamente, enquanto homem é descendente do povo eleito (Mt 1,1-17; Lc 3,23-28).

${ }^{184}$ C.E.B. CRANFIELD. Carta aos Romanos, p. 186-187.

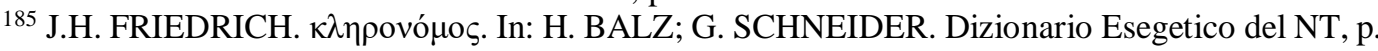
50 .

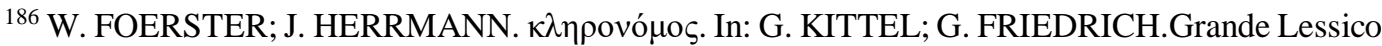
del NT, vol. V, p. 650.

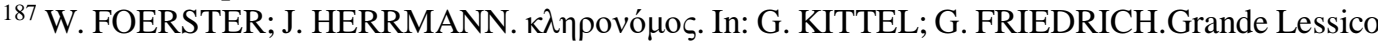
del NT, vol. V, p. 650.
} 


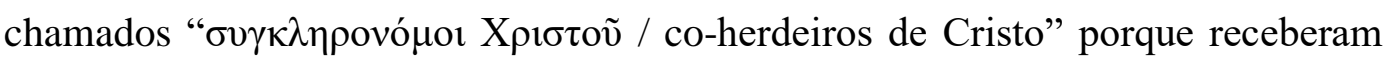
através de Cristo a graça de serem filhos e herdeiros ${ }^{188}$.

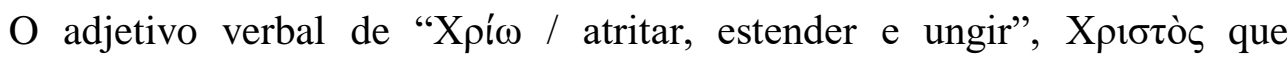

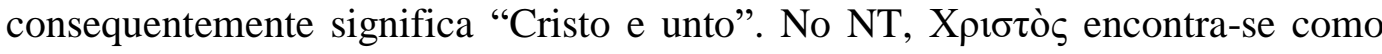
tradução de $M \varepsilon \sigma \sigma i \alpha^{\prime} \varsigma^{189}$, exclusivamente referido a uma pessoa, ou seja, à figura do Messias esperado e desconhecido, como a Jesus de Nazaré, como Messias

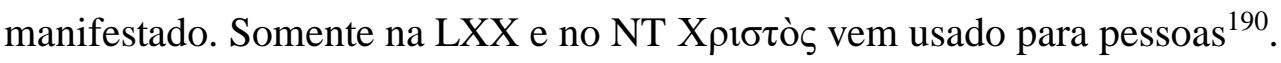

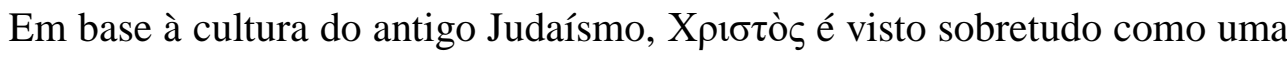
designação de função de uma pessoa unta. É um apelativo que pode ser atribuído a uma figura histórica de Israel ou do tempo final e que exprime uma qualidade de majestade adquirindo um caráter de título ${ }^{191}$.

No NT Xpıбт̀̀ $53 x$ nos Evangelhos, 26x nos Atos dos Apóstolos, 383x no Corpus Paulinum, 12x carta aos Hebreus, 49x nas cartas católicas e 7x no

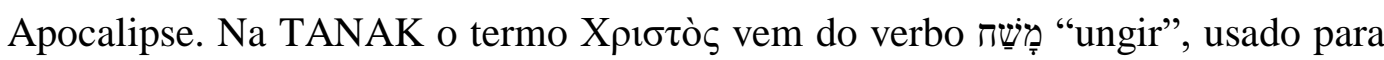
unção de pessoas como: um rei (1Sm 9,16; 10,1.6-9.13; 12,3.5; 16,3.12ss; 24,7.11; 26,9-11.23; 2 Sm 1,14.16; 7,8-16; 19,22; 23,1; $1 \operatorname{Re} 1,34$ ss; $1 \operatorname{Re} 19,15 ; 2 \operatorname{Re} 9,3.6 .12 ;$ Sl 18,51; 132,19; Is 45,1; Jd 9,7-15), um Sumo sacerdote (Lv 4,3.5.16; 6,15; $1 \mathrm{Cr}$ 29,22; Eclo 45,15; Dn 9,25) e profetas (1Re 19,16; 2Re 2,9.15; Sl 105,15; Is $61,1)^{192}$.

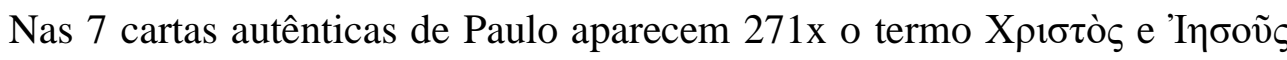

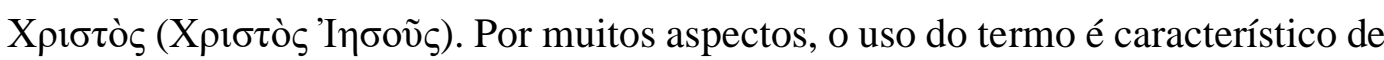
Paulo. Porém, na base, existe um uso linguístico proto-cristão. A partir disto

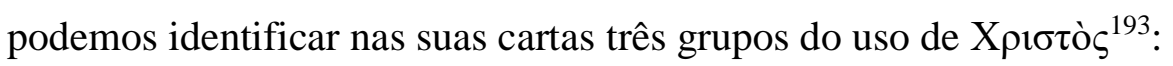

- o primeiro grupo forma um quadro relativamente unitário. A locução

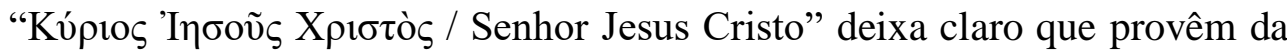

\footnotetext{
${ }^{188}$ R. PENNA. Lettera ai Romani: Rm 6-11 (II), p. 167: "Il costrutto grego $\sigma 0 \gamma \kappa \lambda \eta \rho о v o ́ \mu o$, infatti, suggerisce l'idea di partecipazione a una eredità che è propria di Cristo..."

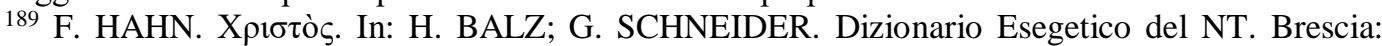
Paideia Editrice, 2004, p. 1937: “A prescindere da concezioni non escatologiche e da un'escatologia coerentemente teocratica, nel giudaismo primitivo si ebbero diverse forme di messianologia. 'Messia' s'incontra solo per la figura attesa per il tempo della salvezza'.

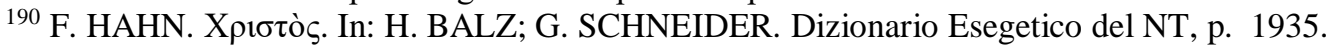

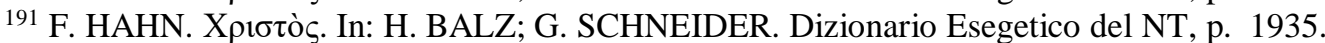

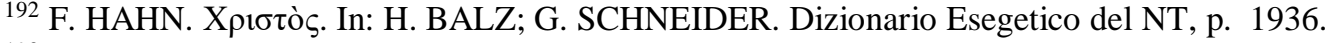

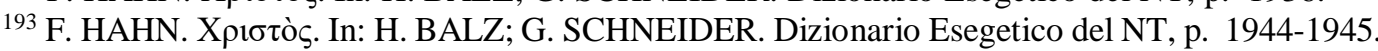


tradição confessional (1Cor 8,6; Fl 2,12;3,20) e litúrgica (Rm 1,7; 13,14; 1Cor 1,3 ; 2 Cor 1,2; 13,13; Gl 1,3; Fl 1,2; 4,23; 1Ts 1,1; Fm 3,25);

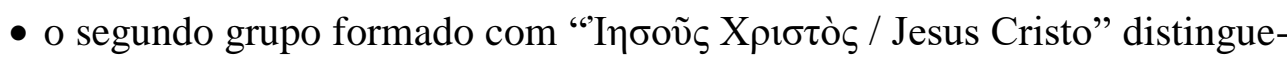
se por um determinado nexo de vocábulos. Paulo fala de si mesmo como

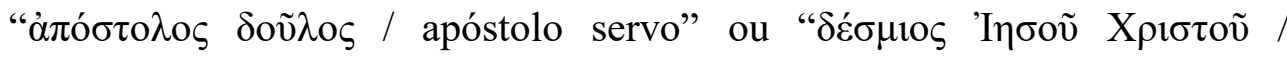
"prisioneiro de Jesus Cristo" (Rm 1,1; 1Cor 1,1; 2Cor 1,1; Fl 1,1; Fm 1,9).

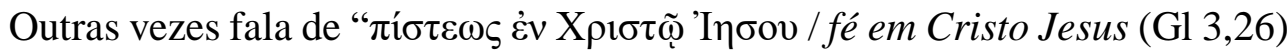

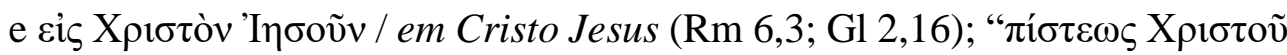

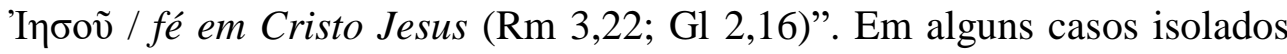

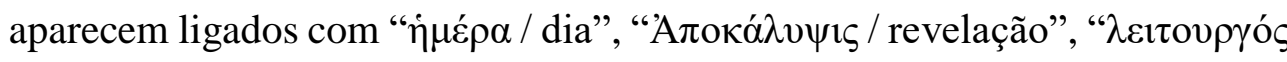
/ servidor" etc.;

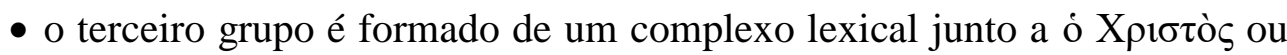

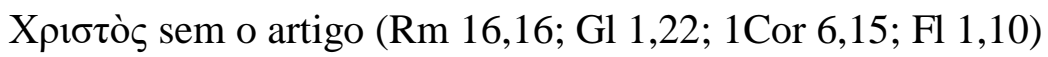

4.4 .2 v. $17 \mathrm{~d} \alpha-17 \mathrm{e} \beta$

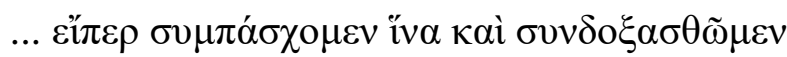

... porque juntos com Ele sofremos para também juntos com Ele sejamos glorificados.

Outro vocábulo importante é " $\sigma u \mu \pi \alpha ́ \sigma \chi 0 \mu \varepsilon v /$ juntos com Ele sofremos". Encontramos já em Platão ${ }^{194}$ o uso do termo $\sigma v \mu \pi \alpha ́ \sigma \chi \omega$ que significa "sofrer contemporaneamente, sofrer junto com, padecer a mesma coisa de". Muito raramente, significa "ter, sentir piedade" (aqui é substituído pelo sinônimo $\sigma \pi \lambda \alpha \gamma \chi v i \zeta o \mu \alpha \imath)$. No NT aparece somente em dois passos da literatura paulina: Rm 8,17 e 1 Cor 12,26. Referido à comunidade, em 1Cor 12,26a, $\sigma u \mu \pi \alpha ́ \sigma \chi \omega$ não significa que se um membro se faz mal, todos os outros membros participam da dor com simpatia e sensibilidade. Mas, ao invés fala de todos serem envolvidos no dano,

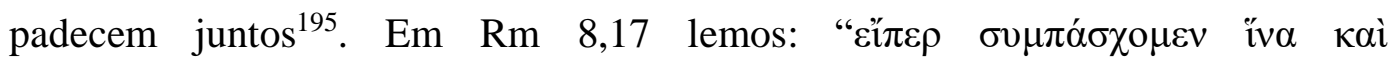

${ }^{194}$ W. MICHAELIS. $\sigma v \mu \pi \alpha ́ \sigma \chi \omega$. In: G. KITTEL; G. FRIEDRICH. Grande Lessico del NT, vol. XII. Brescia: Paideia Editrice, 1974, p. 1046-1047.

${ }^{195}$ W. MICHAELIS. $\sigma v \mu \pi \alpha ́ \sigma \chi \omega$. In: G. KITTEL; G. FRIEDRICH. Grande Lessico del NT, vol. XII, p. 1047. 
$\sigma v v \delta o \xi \alpha \sigma \theta \tilde{\omega} \mu \varepsilon v$ / porque juntos com Ele sofremos para também juntos com Ele sejamos glorificados".

De todo o contexto, conclui-se claramente que $\sigma u \mu \pi \alpha ́ \sigma \chi \omega$ não pode significar

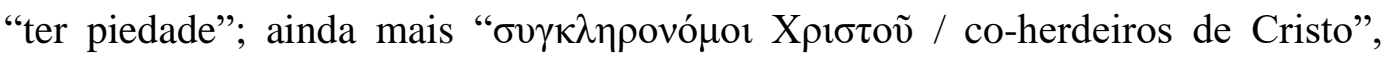
imediatamente precedente, mostra que o prefixo $\sigma v v-$, de $\sigma v \mu \pi \alpha ́ \sigma \chi \omega$, não indica uma comunidade de dor entre os cristãos, mas sim uma relação dos crentes em

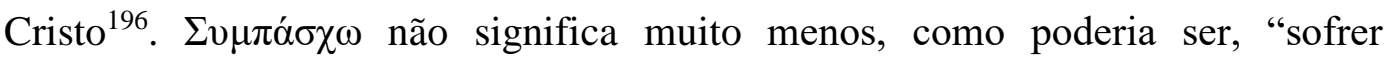

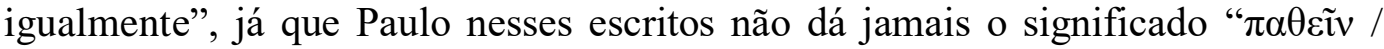

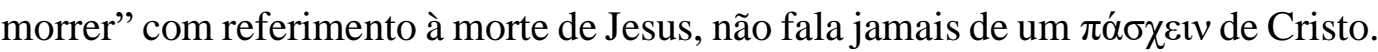
Assim também desaparece a possibilidade que com $\sigma v \mu \pi \alpha ́ \sigma \chi \varepsilon ı v$ o apóstolo queira indicar a comum participação de Cristo e dos cristãos a uma suposta dor complexiva: a ideia de um tal sofrimento coletivo, de modo geral é desconhecida pelos escritos paulinos ${ }^{197}$.

Também a expressão " $\sigma \nu v \delta o \xi \alpha \sigma \theta \tilde{\omega} \mu \varepsilon v$ / juntos com Ele sejamos glorificados" contém a ideia que eles receberam a " $\delta$ ó $\xi \alpha$ / glória” celeste mediante Cristo $^{198}$. Analogamente, significa que com Cristo os cristãos vivem uma situação

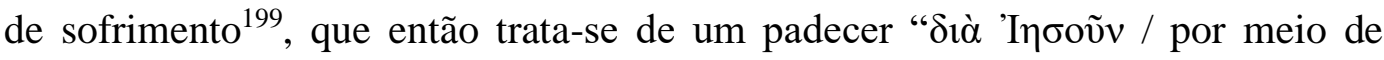

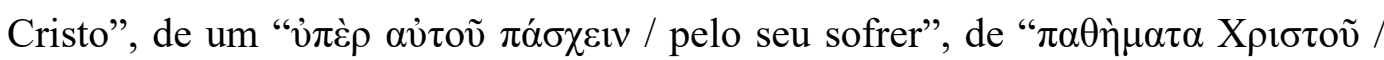
Paixão de Cristo" ${ }^{200}$ refletida na prática da vida cristã, onde seguir a Cristo também implica em passar dificuldades para testemunhar o Evangelho. Neste sentido afirma Légasse $^{201}$ :

Partindo do contexto da comunidade de Roma, é necessário sublinhar que Paulo, de modo diverso das outras cartas, aqui está falando mais dos efeitos das hostilidades externas que das provas internas vividas por qualquer cristão que decide ser fiel à sua vocação. Ainda mais, todos estes sofrimentos não comportam uma participação naquilo que foi objetivo da Paixão de Jesus e necessita excluir das provas cristãs qualquer valor redentor.

\footnotetext{
${ }^{196}$ W. MICHAELIS. $\sigma \nu \mu \pi \alpha ́ \sigma \chi \omega$. In: G. KITTEL; G. FRIEDRICH. Grande Lessico del NT, vol. XII, p. 1047.

${ }^{197}$ W. MICHAELIS. $\sigma 0 \mu \pi \alpha ́ \alpha \chi \omega$. In: G. KITTEL; G. FRIEDRICH.Grande Lessico del NT, vol. XII, p. 1047-1048.

${ }^{198}$ W. MICHAELIS. $\sigma v \mu \pi \alpha ́ \sigma \chi \omega$. In: G. KITTEL; G. FRIEDRICH. Grande Lessico del NT, vol. XII, p. 1048.

${ }^{199}$ J.A. FITZMYER. La Lettera ai Romani: Commentario critico-teologico, p. 598.

${ }^{200}$ W. MICHAELIS. $\sigma 0 \mu \pi \alpha ́ \sigma \chi \omega$. In: G. KITTEL; G. FRIEDRICH.Grande Lessico del NT, vol. XII, p. 1049

${ }^{201}$ S. LÉGASSE. L’Épître de Paul aux Romains, p. 509.
} 
Entretanto, Paulo sabe que o sofrimento é algo muito concreto pela sua experiência e, por isso, fixa uma intenção insubstituível, que não é subjetiva, mas objetivamente cristológica, a essa dura realidade humana, como nos recorda Pitta ${ }^{202}$ :

Graças à fé e ao batismo os cristãos crescem juntos a Cristo $(\mathrm{Rm}$ 6,5) e participam da sua paixão, do seu sofrimento e morte. Assim, Paulo não diminui a responsabilidade dos cristãos de colaborar com Cristo. Em outras palavras, é importante que eles participem do sofrimento de Jesus, pois a participação na herança de Cristo depende, também, de modo definitivo da participação no seu sofrimento e na sua Glória. Por isso, os termos compostos com a preposição $\sigma v v-$ (co-herdeiros, com sofrimento, e ser co-glorificados) não têm tanto uma dimensão antropológica ou eclesial, no sentido que a participação nos sofrimentos dos outros fosse para nós garantia para a nossa participação da glória e a herança final, mas estes verbos de participação têm uma consistente dimensão cristológica. Então com sofrimento quer dizer participar antes de mais nada da morte de Cristo e ser coglorificados, ou seja, dividir com Cristo a sua ressurreição.

Portanto, com toda a reflexão feita, agora podemos responder à pergunta elaborada no início do comentário exegético onde a questão se configurava como: qual seria a vida daqueles que pelo Espírito mortificam as obras da carne? Com todo percurso realizado podemos afirmar que, se estamos no Espírito e o Espírito está guiando-nos, podemos mortificar as ações da carne para responder melhor a Deus, por nos ter dado tão grande dádiva, que é a filiação divina, nesta peregrinação terrena nos concedendo a herança (Ef 1,3-4) do reino de Deus, pelo batismo na Paixão, Morte e Ressurreição de Cristo Jesus, para que também no kaıрó s oportuno, participemos com Ele da sua glória na morada eterna ${ }^{203}$. É esta a vida prometida por Cristo, quando, no final do seu peregrinar na terra, diz aos seus discípulos, e que serve também para cada um de nós, segundo o Evangelista João 14,1-4, que nos convida a uma confiança profunda nas mãos do Senhor:

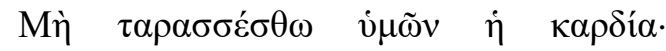

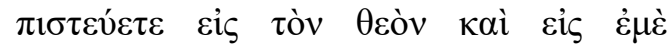

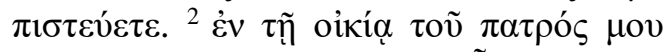

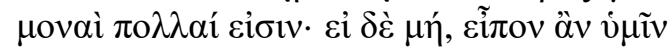

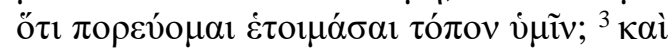

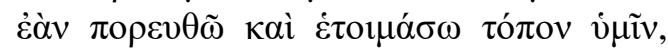

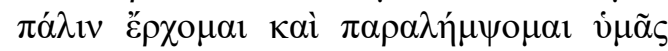

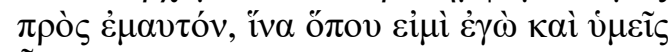

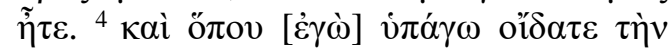
ódóv.
Não se perturbe o vosso coração. Credes em Deus, crede também em mim. Na casa de meu Pai há muitas moradas. Se não fosse assim, eu vos teria dito; pois vou preparar-vos um lugar, virei novamente e vos levarei comigo, a fim de que, onde eu estiver, estejais vós também. E para onde vou, conheceis o caminho.

\footnotetext{
202 A. PITTA. Lettera ai Romani: Nuova versione, introduzione e commento, p. 299.

203 I. MAZZAROLO. A Carta aos Romanos: Educar para a maturidade e o amor, p. 104; U. WILCKENS. La carta a los Romanos 6-16 (II), p. 172.
} 


\section{Síntese teológica de $\mathrm{Rm} \mathbf{8 , 1 4 - 1 7}$}

Como comentamos nos capítulos anteriores, a Carta aos Romanos é tida como o escrito mais ou um dos mais importantes de todo o epistolário paulino e o escrito neo-testamentário que mais criou interesses nos estudos bíblicos, causando muitas novidades na história. $\mathrm{O}$ estudo da investigação exegética pode levar a uma meditação teológica conduzindo-nos a colher uma mensagem hoje para a nossa vida. Por isso, o hodierno estudo que fizemos da compreensão do texto sobre $\mathrm{Rm}$ 8,14-17 nos leva à conclusão, entre tantos temas do capítulo 8, que o tema referente ao do Espírito Santo ${ }^{204}$ tem valor preponderante em toda a Carta aos Romanos.

O Espírito Santo é designado pela palavra grega $\pi v \varepsilon \tilde{u} \mu \alpha$ e seus derivados

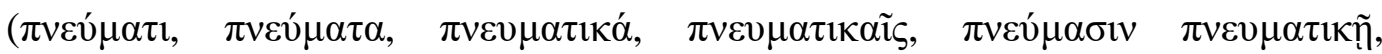
$\pi v \varepsilon v \mu \alpha \tau 1 \kappa \tilde{\eta} \varsigma, \pi v \varepsilon v \mu \alpha \tau 1 \kappa o i ́, ~ \pi v \varepsilon v \mu \alpha \tau 1 \kappa o i ̃ \varsigma, ~ \pi v \varepsilon v \mu \alpha \tau 1 \kappa o ́ v, ~ \pi v \varepsilon v \mu \alpha \tau 1 \kappa o ́ \varsigma, ~ \pi v \varepsilon v \mu \alpha \tau 1 \kappa \tilde{\omega} v$, $\pi v \varepsilon v \mu \alpha \tau \iota \kappa \tilde{\omega} \zeta, \pi v \varepsilon v ́ \mu \alpha \tau o \zeta, \pi v \varepsilon v \mu \alpha ́ \tau \omega v)$ que se encontram $182 \mathrm{x}$ no epistolário paulino e na Carta aos Hebreus, sendo que somente na Carta aos Romanos encontramos $37 \mathrm{x}$.

A palavra $\pi v \varepsilon \tilde{u} \mu \alpha$ e seus derivados aparecem $21 \mathrm{x}$ neste capítulo no qual constitui-se a palavra chave e demonstrando o quanto fosse caro ao apóstolo Paulo. Na sessão estudada, a palavra $\pi v \varepsilon \tilde{u} \mu \alpha$ é citada 3x e o seu derivado $\pi v \varepsilon v ́ \mu \alpha \tau \imath 2 x$. Por esta frequência na perícope, já podemos ter uma ideia da importância do Espírito para o apóstolo. Antes de introduzir e entender como o apóstolo Paulo concebe o Espírito veremos a partir de agora um panorama geral no epistolário paulino e na Carta aos Hebreus a frequência do termo $\pi v \varepsilon \tilde{u} \mu \alpha$ e seus derivados:

${ }^{204}$ G. BARBAGLIO. La Teologia di Paolo, p. 642. 


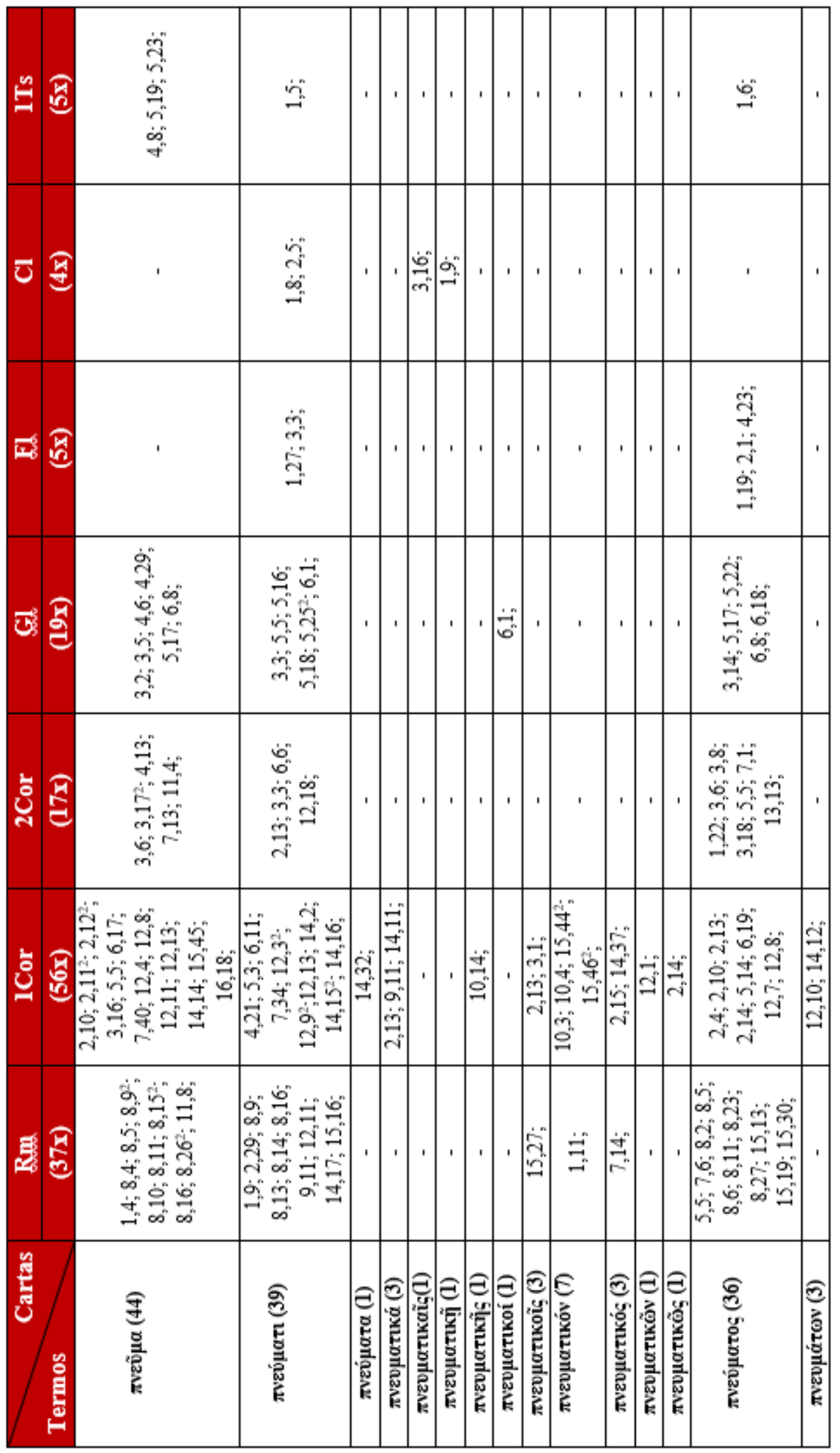




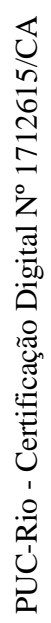

\begin{tabular}{|c|c|c|c|c|c|c|c|c|c|c|}
\hline 照 & d્d & 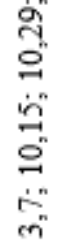 & & $\begin{array}{l}\stackrel{+}{ \pm} \\
- \\
\stackrel{-}{-} \\
-\end{array}$ & ' & $\begin{array}{l}\ddot{n} \\
\text { à }\end{array}$ & ' & ' & 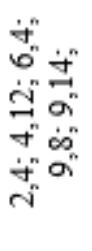 & $\begin{array}{l}\text { gे } \\
\text { In }\end{array}$ \\
\hline$\ddot{B}$ & 뜰 & ' & ' & ' & ' & ' & ' & ' & $\ddot{m}$ & ' \\
\hline 貝 & 居 & $\stackrel{=}{\Rightarrow}$ & & ' & ' & ' & ' & ' & 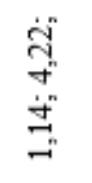 & ' \\
\hline 思 & 疱 & $\ddot{-}$ & $\stackrel{\ddot{m}}{m}$ & ' & ' & $\overrightarrow{7}$ & ' & ' & ' & ' \\
\hline 茨 & 局 & ' & هon & ' & ' & ' & ' & ' & 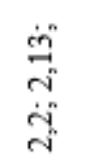 & ' \\
\hline 被 & E & 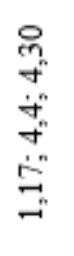 & 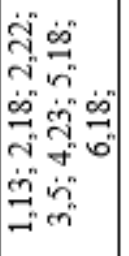 & ' & בี & ' & iे & $\stackrel{\eta}{\sim}$ & 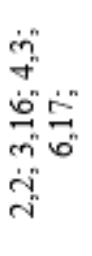 & ' \\
\hline $\overrightarrow{\mathrm{E}}$ & 息 & 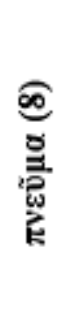 & 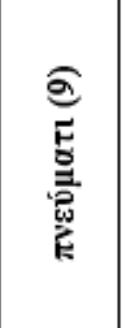 & 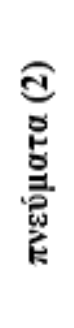 & 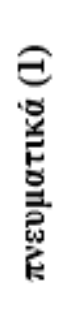 & 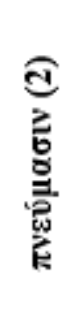 & 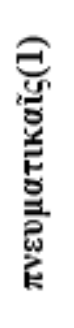 & 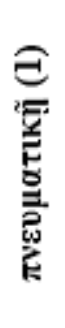 & 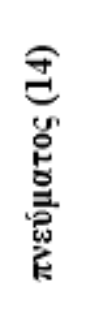 & 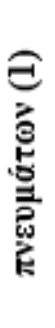 \\
\hline
\end{tabular}




\subsection{O Dom do Espírito}

\subsubsection{O Espírito / $\pi v \varepsilon \tilde{u} \mu \alpha$}

No grego profano o termo $\pi v \varepsilon \tilde{u} \mu \alpha$ é usado frequentemente no sentido semântico entusiástico, ou seja, relativo à aspiração e mais tarde como expressão de uma substância vital cósmica-universal e divina ${ }^{205}$.

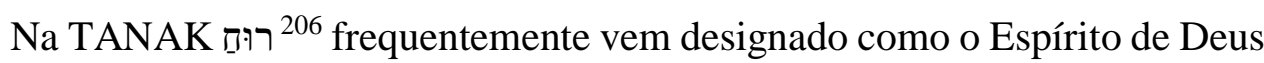
que age como força vital e doa dons particulares ou inspira determinadas pessoas. Somente no período pós-exílico passa a ser considerado o conceito de Espírito Santo. Por influência dos mundos contemporâneos da época, o termo ㄲำ ( $\pi v \varepsilon \tilde{u} \mu \alpha)$ no Judaísmo passa a ser termo técnico para designar seres sobrenaturais bons e maus, sem contar que, no ambiente helenístico, o termo $\pi v \varepsilon v \tilde{\mu} \alpha$ normalmente é concebido como substância por causa de concepções filosóficas gregas, ou por especulações sobre a sabedoria ${ }^{207}$.

No NT o vocábulo $\pi v \varepsilon \tilde{u} \mu \alpha$ é caracterizado essencialmente pelo equivalente hebraico 밈 e pelo seu significado no Judaísmo, como "vento" e "respiro". Não obstante isso, os dois termos não falam de realidade substanciosa, mas de uma força que se encontra no respiro e na rajada do vento, no qual permanece misterioso o fato donde vem e para onde vai ${ }^{208}$.

No NT $\pi v \varepsilon \tilde{u} \mu \alpha$ encontra-se complexivamente 379x e somente três dessas citações há um inequivocamente um sentido original de "vento e sopro (impetuoso)". Normalmente designa o $\pi v \varepsilon \tilde{u} \mu \alpha$ do homem (47x), como espíritos malvados (38x) e espíritos dos defuntos ou dos anjos (9x); muitas vezes indica o $\pi v \varepsilon \tilde{v} \mu \alpha$ de Deus (275x), onde vem escrito sem a personificação - de Deus - ou mais

\footnotetext{
${ }^{205}$ J. KREMER, $\pi v \varepsilon v \tilde{\mu} \alpha$. In: H. BALZ; G. SCHNEIDER. Dizionario Esegetico del NT, p. 1011. ${ }^{206}$ H. OBERMAYER et al. Spirito. In: H. OBERMAYER; K. SPEIDEL; K. VOGT; et. al. ed. Piccolo Dizionario Biblico. Cinisello Balsamo: San Paolo Edizioni, 1997, p. 305-306: "La parola ebraica usata per indicare lo spirito originalmente significa soffio de vento (Êx 10,13), respiro della vita (Gen 7,15; Mt 27,50), ed indica anche il fatto che un uomo ha saziato la sua fame o la sua sete e ha ripreso coraggio (Giud. 15,19) testo originale di Gen 45,27. Jahvé è Signore di questo respiro della vita $($ Gen 2,7$)$ ed è lui che fa vivere (Ez 37,1-14). Tuttavia egli può riprendersi anche questo spirito della vita (Giob. 34,14ss.). In seguito ci si chiede che cosa accada con questo 'spirito' dopo la morte di un uomo ( $\mathrm{Lc} 23,46)$. Il termine spirito può indicare anche un modo di comportarsi ('Spirito di smarrimento' Is 19,14). Lo spirito di Dio comunica specialmente forza e sostegno (Num 11,25; Giud. 14,6; Lc 1,15; 4,14)".

${ }^{207}$ J. KREMER. $\pi v \varepsilon \tilde{\mu} \mu \alpha$. In: H. BALZ; G. SCHNEIDER. Dizionario Esegetico del NT, p. 1012.

${ }^{208}$ J. KREMER. $\pi v \varepsilon \tilde{u} \mu \alpha$. In: H. BALZ; G. SCHNEIDER. Dizionario Esegetico del NT, p. 10111012.
} 


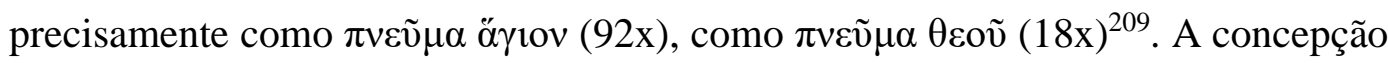
paulina do Espírito aparece em três fontes ${ }^{210}$ principais:

- a revelação no cânon do AT;

- o judaísmo intertestamentário;

- o pensamento da Igreja primitiva.

Com relação a isto, Paulo foi muito influenciado pela experiência pessoal com o Espírito e com a experiência das comunidades que ele fundou. É importante constatar que na TANAK algumas vezes o "Espírito de Deus" vem chamado de Santo (S1 51,13; Sb 9,17; Is 63,10-11; Dn 13,44), porém esta atribuição passa a ser comum no período intertestamentário. As raízes veterotestamentárias tornam-se evidentes no fato que para Paulo o Espírito é único e singular. Por isso, para Paulo falar do Espírito Santo significa falar da presença e do Poder de Deus ${ }^{211}$. Como Deus é único assim também existe um só Espírito de Deus (1Cor 12,4-6.11.13; Ef 4,4-6).

Desde a antiguidade, o Espírito Santo tem sido unido à profecia (Nm 11,29; 1Sam 10,6; 19,20-24; Mq 3,8; Ez 11,5; Eclo 48,12.24;) e, sobretudo, nos profetas assume uma característica moral, sendo associado à justiça, ao juízo e à vida na Aliança (Is 4,4; 28,5-6; 59,21; 63,10; Ez 36,26-27; 39,27-29; S1 51,10-11; 143,10). O AT exprime a esperança que esse Espírito vivificador da profecia e de uma vida conforme à Aliança será um elemento da futura era messiânica de bênçãos (Is 32,15; 44,3; Ez 36,25-27; 39,28-29; J1 3,1-2).

Paulo herda da fé do seu povo, não obstante não se encontrem somente no mundo hebraico, ainda duas ideias que são importantes para a compreensão do Espírito: a associação do Espírito com a Força (2Re 2,9-15; Jz 6,34-35; 14,19; 15,14-15) e com a vida enquanto potência vivificadora que tem em Deus a própria origem (Gn 1,2; 6,3; S1 104,29-30; Jó 32,8; Is 42,5; Ez 37,4-14). Não obstante toda esta construção da concepção paulina de Espírito, é importante ressaltar que a mesma não é uma simples continuação da ideia do AT e do Judaísmo, porque nos

\footnotetext{
${ }^{209}$ J. KREMER. $\pi v \varepsilon \tilde{u} \mu \alpha$. In: H. BALZ; G. SCHNEIDER. Dizionario Esegetico del NT, p. 1012.

${ }^{210}$ T. PAIGE. Spirito Santo. In: G.F. HAWTHORNE; R.P. MARTIN; D.G. REID. Dizionario di Paolo e delle sue Lettere. Cinisello Balsamo: San Paolo Edizioni, 2000, p. 1489.

${ }^{211}$ T. PAIGE. Spirito Santo. In: G.F. HAWTHORNE; R.P. MARTIN; D.G. REID. Dizionario di Paolo e delle sue Lettere, p. 1490.
} 
escritos paulinos o Espírito tem uma relevância quantitativa que é muito superior àquela do AT Esta realidade quantitativa pode ser explicada pelo fato de que as primeiras comunidades cristãs experimentaram a presença do Espírito Santo na vida deles (At 2, 37-47; 3,32-37; 11,19-26; 1Cor 2,10-12; 3,16; 7,40; 12,11.13) ${ }^{212}$ :

- como a percepção de uma presença divina no culto;

- como os milagres operados e as inspirações da profecia;

- como o fato de ter anunciado o Evangelho com coragem, sabedoria e usufruindo desta alegria mesmo nas dificuldades.

Toda esta realidade demostra a Paulo uma grande esperança escatológica ${ }^{213}$ do AT com relação à promessa do Espírito Santo, onde esta vinda é sinal concreto para os primeiros cristãos que o Senhor ressuscitado, ou seja, Jesus Cristo, era verdadeiramente o Messias esperado ${ }^{214}$ (Ez 36,25-27; Jo 16,7-11; At 2,14-24.36.3839; Gl 3,1-5.14; Ef 1,13).

É importante também sublinhar que Paulo não vê no Espírito uma força que é sempre disponível às ordens daquele que crê, como por exemplo na cultura pagã onde se diziam que os demônios e os espíritos socorriam os magos em qualquer de suas intenções. Por isso, o Espírito não pode ser controlado com atos e encantos particulares. Porém, Ele está presente para ajudar todo aquele que crê a realizar a vontade de Deus ${ }^{215}$.

${ }^{212}$ T. PAIGE. Spirito Santo. In: G.F. HAWTHORNE; R.P. MARTIN; D.G. REID. Dizionario di Paolo e delle sue Lettere, p. 1490-1491; É importante ressaltar que Paulo viveu em primeira pessoa a mesma experiência.

213 T. PAIGE. Spirito Santo. In: G.F. HAWTHORNE; R.P. MARTIN; D.G. REID. Dizionario di Paolo e delle sue Lettere, p. 1500-1501: "Paolo considera lo Spirito, riversato sui credenti, come un segno escatologico che indica che sono già iniziate la salvezza e la restaurazione promesse da Dio al suo popolo. Questa prospettiva escatologica ha qualche precedente nell'AT e nella speranza rabbinica di uno dono generale dello Spirito nell'era futura, e anche in alcune espressioni dei testi di Qumran (Sekki 82-83). La differenza rispetto a Paolo è che lo Spirito rappresenta l'irruzione di questo tempo finale nel presente. Vi è eco escatologica anche nella concezione dello Spirito come 'primizia' e come 'caparra' ( $\alpha \rho \rho \alpha \beta \tilde{\omega} v \alpha)$ per i credenti di ciò che riceveranno quando il regno messianico se sarà realizzato pienamente, il giudizio sarà effettuato e ogni nemico di Dio sarà sconfitto (Rom 8,18-25; 2 Cor 1,22; 5,5; Ef 1,13-14; 4,30). Pertanto nel tempo presente lo Spirito è nello stesso tempo una componente della vita e del potere dell'età futura, e un segno che rimanda al di là del presente e dice ai credenti che non è ancora giunta la pienezza del tempo messianico: 'La creazione stessa attende con impazienza la rivelazione dei figli di Dio..., ma anche noi, che possediamo le primizie dello Spirito, gemiamo interiormente aspettando la (nostra) adozione a figli, la redenzione del nostro corpo' (Rom 8,19.23)".

214 T. PAIGE. Spirito Santo. In: G.F. HAWTHORNE; R.P. MARTIN; D.G. REID. Dizionario di Paolo e delle sue Lettere, p. 1491.

215 T. PAIGE. Spirito Santo. In: G.F. HAWTHORNE; R.P. MARTIN; D.G. REID. Dizionario di Paolo e delle sue Lettere, p.1491: "E mentre la magia antica riteneva che un aiuto soprannaturale 


\subsubsection{O Espírito de Deus}

Para Paulo o Espírito Santo é o Espírito de Deus que, de acordo com o AT e a literatura judaica intertestamentária, é único e particular no seu poder e na sua relação com Deus (1Cor 2,11; Rm 8,9.11; 2Cor 3,17; Ef 4,4). Quando Paulo fala do Espírito que foi dado aos cristãos, ele sempre pronuncia no singular: Espírito Santo ou Espírito de Deus (Rm 8,9; 1Cor 3,16; 12,4-6; 2Cor 5,5; Gl 3,5). Esta unidade do Espírito pode ser adotada como argumento teológico para comprovar a unidade da

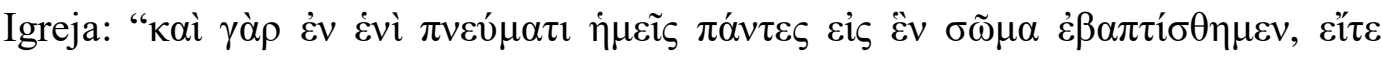

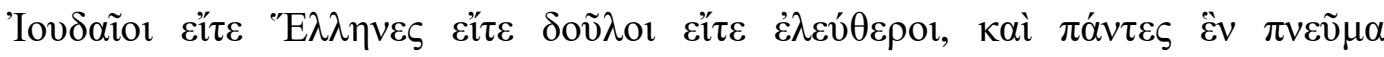
$\varepsilon \dot{\pi} \tau^{\prime} \tilde{\sigma} \sigma \eta \mu \varepsilon v$ / Pois fomos todos batizados num só Espírito para sermos um só corpo, judeus e gregos, escravos e livres; e todos bebemos de um só Espírito" (1Cor 12,13). Para Paulo o Espírito é sinal da presença de Deus entre o seu povo, de modo particular quando pronuncia discursos inspirados, sobretudo na proclamação do Evangelho, das profecias; quando dá coragem, quando exorta, quando ensina e quando fazem milagres (1Cor 12,4-11; 1Ts 1,5 ; Gl 3,1-5) ${ }^{216}$.

\subsubsection{O Espírito de Cristo}

Vanni ${ }^{217}$ diz que para compreender especialmente o que é o Espírito de Cristo em Paulo devemos recorrer ao Evangelho segundo João 20,19.22, que descreve a aparição de Jesus aos discípulos na noite de Páscoa. O evangelista ${ }^{218}$ afirma que:

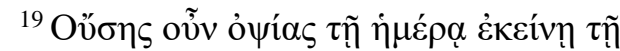

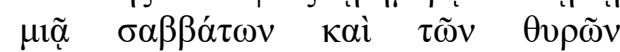

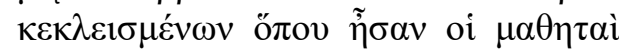

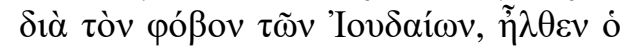

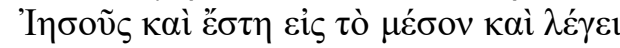

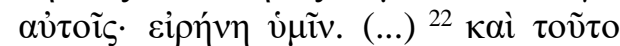

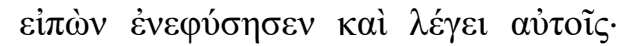

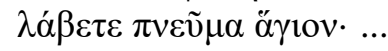

19 À tarde deste mesmo dia, o primeiro da semana, estando fechadas as portas onde se achavam os discípulos, por medo dos judeus. Jesus veio e pondo-se no meio deles, lhes Disse: "A Paz esteja convosco!" (...) ${ }^{22}$ Dizendo isto, soprou sobre eles: "Recebei o Espírito Santo"...

fosse prestato solo a poche persona dotate de una conoscenza esoterica (non importa per quali scopi), lo Spirito viene dato a tutti liberamente, alla sola condizione che si creda in Cristo come Signore (1Cor 12,3)".

216 T. PAIGE. Spirito Santo. In: G.F. HAWTHORNE; R.P. MARTIN; D.G. REID. Dizionario di Paolo e delle sue Lettere, p. 1491.

${ }^{217}$ U. VANNI. L'ebbrezza nello Spirito. Roma: Edizioni ADP, 2000, p. 77.

${ }^{218}$ F. PORSH. $\pi \alpha \rho \alpha ́ \kappa \lambda \eta \tau$ ○. In: H. BALZ; G. SCHNEIDER. Dizionario Esegetico del NT. Brescia: Paideia Editrice, 2004, p. 780. Na concepção joanina Jesus, para os discípulos, é considerado o primeiro $\pi \alpha \rho \alpha ́ \kappa \lambda \eta \tau o \varsigma$ 'paráclito' sendo assim o Espírito Santo é o segundo: "E eu rogarei ao Pai, e Ele vos dará outro Paráclito, para que fique eternamente convosco" (Jo 14,16). 
Quem aparece no meio deles é Jesus Cristo ressuscitado com as marcas da paixão, tendo em si o desejo de doar-se aos seus discípulos, dizendo "A Paz esteja convosco" (Lc 24,36; Jo 20,19-23.26). Aqui, a Paz é o mesmo Jesus, que se comunica e sopra o seu Espírito sobre os seus discípulos. Um gesto parecido acontece também no livro do Gênesis quando Deus cria Adão (Gn 1,26; 2,7). Assim, desse gesto se pode intuir quem é o Espírito Santo, o Espírito de Cristo de modo analógico à compreensão que tiveram os discípulos, isto é, o " $\pi \alpha \rho \alpha ́ \kappa \lambda \eta \tau o \varsigma$ 219/ defensor", é a vitalidade de Jesus ressuscitado que é passada para os discípulos ${ }^{220}$. E, verdadeiramente, é a realidade do ressuscitado que dá um novo sentido à vida do Apóstolo Paulo. No livro dos Atos dos Apóstolos encontra-se descrito como Paulo muda de vida a partir de seu encontro com o Ressuscitado (At 9,1-9; 22,6-11).

Para Paulo, "a essência espiritual da religião é uma realidade admitida sem muita explanação"221, pois tanto para ele quanto para os seus predecessores a experiência e a manifestação fundamental do Espírito estão na natureza conforme a de Jesus, ou seja, o Espírito possui a mesma característica de Jesus.

Paige $^{222}$ afirma que um dos aspectos mais significativos da doutrina de Paulo sobre o Espírito, e que o distingue da fé israelita e judaica, é a profunda conexão do Espírito com o Senhor Jesus, isto é, aquilo que foi chamado o caráter Jesuânico do Espírito. Portanto, o Espírito é chamado o Espírito de Cristo ou o Espírito do Filho de Deus (Rm 8,9; Gl 4,6). Com isso, se pode afirmar que o Espírito transforma o coração daquele que crê2 $\hat{2}^{223}$, de modo que ele reproduza as mesmas características

\footnotetext{
${ }^{219}$ H. OBERMAYER et al. Paraclito. In: H. OBERMAYER; K. SPEIDEL; K. VOGT; et. al. ed. Piccolo Dizionario Biblico, p. 242: "Il termine Paraclito che significa intercessore, assistente e erroneamente alcuni traducono 'consolatore'. Il termine 'Paraclito' si incontra solo nei 'discorsi d'addio' di Gesú in Gv 14,16.26; 16,7 ed in 1Gv 2,1. Tutti i tipi di intercessori dell'apocalittica giudaica vengono superati in modo insospettato dal Paraclito. Una volta esso appare come una fonte impersonale di rinvigorimento (Gv 14,17), un'altra volta piuttosto come persona (Gv 16,13). La concezione dello Spirito Santo propria della teologia dogmatica e della fede della Chiesa, pur tenendo conto di questa diversità, ha un suo solido fondamento anche nei testi giovannei che parlano del Paraclito (Gv 14,16), dato che anche Gesù Cristo è chiamato Paraclito nella tradizione giovannea $(1 \mathrm{Gv} 2,1)$. Al posto del Cristo risuscitato egli deve testimoniare nel mondo la presenza attiva di Dio e mostrare la via ai discepoli".

${ }^{220}$ U. VANNI. L'ebbrezza nello Spirito, p. 77.

${ }^{221}$ D. GUTHRIE; R.P. MARTIN. Dio. In: G.F. HAWTHORNE; R.P. MARTIN; D.G. REID. Dizionario di Paolo e delle sue Lettere, p. 454.

${ }^{222}$ T. PAIGE. Spirito Santo. In: G.F. HAWTHORNE; R.P. MARTIN; D.G. REID. Dizionario di Paolo e delle sue Lettere, p. 1493.

${ }^{223}$ S. BRODEUR. La dimensione escatologica de la morale cristiana in Rom 8. StMor 36. Roma: Editore Pontificia Universitá Gregoriana, 1988, p. 398: "E questa nostra fede nell'azione salvifica di Dio ci permette di anticipare il futuro con fiducia e di vivere nel presente con 'speranza' (غ̇ $\left.\lambda \pi^{i} \varsigma\right)$ ".
} 
do Senhor Jesus Cristo (2Cor 3,3; Ef 1,16-18), estando em comunhão com Ele (1Cor 1,9) e, assim, com o Espírito Santo (2Cor 13,13; Fl 2,1).

\subsubsection{O espírito do homem}

O texto da Carta aos Romanos, trabalhado nesta dissertação, menciona que mesmo Espírito testemunha ao nosso espírito que somos filhos de Deus $(\mathrm{Rm} 8,16)$, mas quem é esse "nosso espírito" pelo qual o Espírito Santo testemunha que somos filhos de Deus? Quando falamos de "espírito do homem" não se trata de um componente psicológico articulado, mas sobretudo do "eu" com os seus projetos ( $R m$ 2,11), seus sentimentos (1Cor 16,18), e seu conhecimento (1Cor 2,11 como autoconhecimento). Pode-se pensar também em oposição ao corpo (1Cor 7,34; 2 Cor 7,1; 1Tes 5,23) e separado do corpo (1Cor 5,3.5; Cl 2,5). É sobre este "eu" que o Espírito dá testemunho (Rm 8,15ss.; 1Cor 2,11; Gl 6,18); às vezes o "eu" apresenta-se como um espírito de mansidão, de amor, de compreensão, compaixão etc. sob o influxo do Espírito Santo (1Cor 4,21): assim Paulo caracteriza-o referindo-se ao seu ministério $(\mathrm{Rm} 1,9)$ ou ao carisma do poder apostólico (1Cor $5,5 ; \mathrm{Col} 2,25)$.

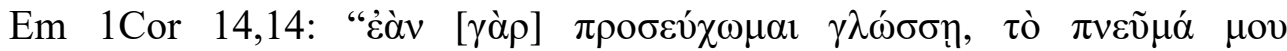

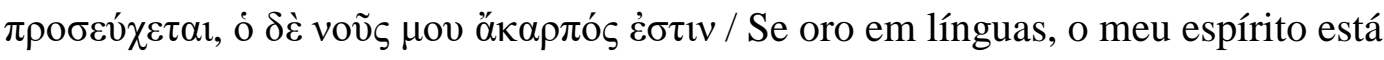
em oração, mas a minha inteligência nenhum fruto colhe". Paulo opõe este espírito à razão: neste caso, sua linguagem é parecida à de Filon de Alexandria ${ }^{224}$ que concebe o espírito como força estática superior à razão e capaz de destronar no momento da inspiração. Em tal modo, Paulo usa a mesma maneira de exprimir-se dos estáticos de Corinto, com a qual combate a supervalorização dos espíritos inspiradores (1Cor 14,12 onde temos o plural, como também em 1Cor 14,32 onde se fala da inspiração dos profetas em Ap 22,6), porque ele submete o êxtase ao Amor (1Cor 12,31-13,1; 14,15ss.) ${ }^{225}$.

\footnotetext{
${ }^{224}$ E. KAMLAH. Spirito. In: L. COENEN; E. BEYREUTHER; H. BIETENHARD; et al. Dizionario dei Concetti Biblici del NT. Bologna: EDB, 1976, p. 1791.

${ }^{225}$ E. KAMLAH. Spirito. In: L. COENEN; E. BEYREUTHER; H. BIETENHARD; et al. Dizionario dei Concetti Biblici del NT, p. 1791.
} 


\subsection{O Espírito na Filiação Divina}

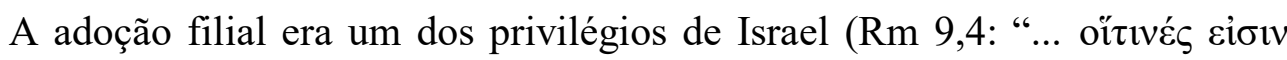

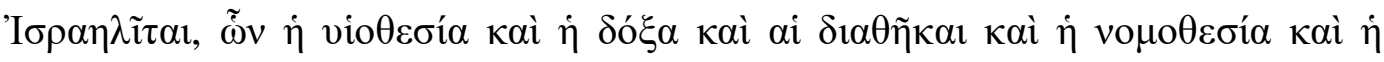

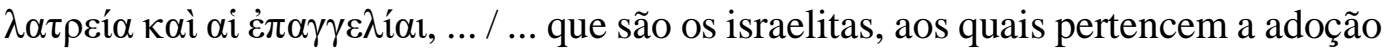
filial, a glória, as alianças, a legislação, o culto, as promessas, ...”). Porém, agora os cristãos são filhos de Deus, num sentido muito mais forte, pela fé em Cristo (Gl 3,26; Ef 1,5). No Filho Unigênito de Deus - Jesus Cristo - pela ação do Espírito Santo, todo homem na adesão à fé passa a participar da vida de Deus (Gl 3,26; Ef 1,$13 ; 3,16-17$ ), de modo que a filiação manifesta consigo uma ligação entre a fé (o Batismo), a ação do Espírito Santo e o ser filho. No batismo, unimo-nos à MorteSepultura e à Ressurreição de Cristo (Rm 6,3-5; Col 2,12), que pelo Espírito Santo

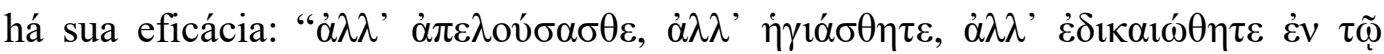

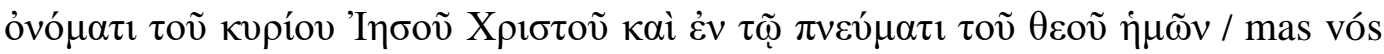
vos lavastes, mas fostes santificados, mas fostes justificados em nome do Senhor Jesus Cristo, e pelo Espírito de nosso Deus" (1Cor 6,11; 1Cor 12,13), que é quase como o instrumento, a causa eficiente do pertencer a Deus. Ilustrativo, neste sentido, é o texto que encontramos na Carta a Tito 3,5-6:

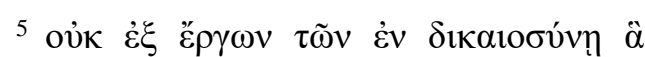

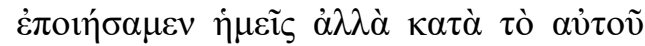

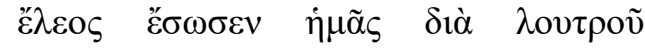

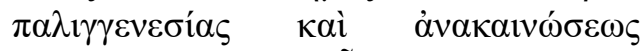

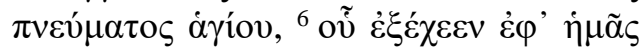

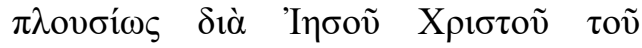

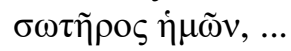

${ }^{5}$ não por causa dos atos que houvéssemos praticado, mas porque, por sua misericórdia, fomos lavados pelo poder regenerador e renovador do Espírito Santo, ${ }^{6}$ que ele ricamente derramou sobre nós, por meio de Jesus Cristo, nosso Salvador, ...

Esse renascer pelo Espírito Santo que encontramos mencionado na Carta a

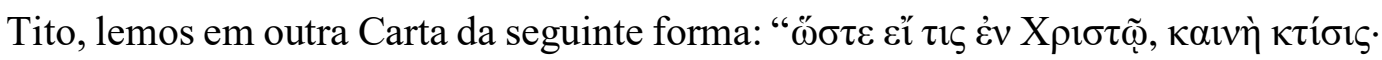

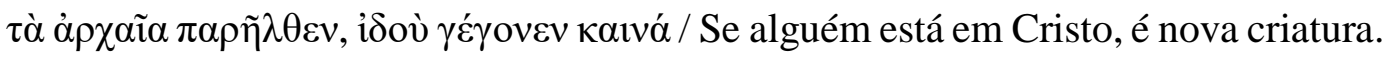
Passaram-se as coisas antigas; eis que se fez uma realidade nova!" (2Cor 5,17; cf. Ef 2,$15 ; \mathrm{Cl} 3,10-11)^{226}$.

\footnotetext{
${ }^{226}$ S. ZEDDA. Prima lettera di San Paolo, p. 464
} 
A transformação em Cristo é obra do Senhor que é Espírito (2Cor 3,18). Passa a ser Espírito vivificante (1Cor 15,45) que age, entra em contato com as almas mediante o espírito. De fato, o ser de Cristo, o pertencer a Cristo, e tê-lo em si é uma realidade concreta somente na medida em que o ser humano tem, operando em si mesmo, o Espírito de Cristo ( $R m$ 8,19-10). A Ressurreição de Jesus nos garante uma adoção perfeita ( $\operatorname{Rm} 8,23)$, é o fruto da presença do Espírito Santo ( $R m$ 8,11) mencionado solenemente no Filho de Deus $(\operatorname{Rm~} 1,4)$.

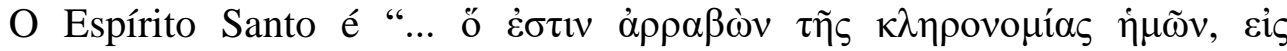

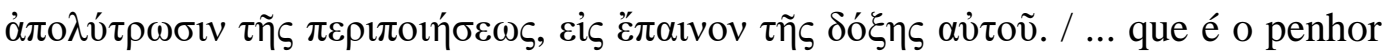
da nossa herança, para a redenção do povo que ele adquiriu para seu louvor e glória.” (Ef 1,14), as primícias daquela que será a adoção perfeita, a redenção do corpo na Ressurreição ( $\operatorname{Rm} 8,23)$. Portanto, o dom do Espírito Santo nesta terra, faz parte da adoção futura começada, e constitui como na sua plena efusão, a filiação divina perfeita. Por isso, todos aqueles que se deixam mover pelo Espírito de Deus,

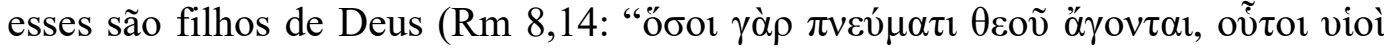
$\theta \varepsilon o v ̃$ ciøıv / De fato, todos aqueles que são conduzidos pelo Espírito de Deus, esses são filhos de Deus").

Ser filho de Deus significa estar sob a moção do Espírito Santo. O apóstolo Paulo acrescenta que temos um espírito filial, um dom de confidência filial, um dom espiritual vindo do Espírito Santo que testemunha ao nosso espírito que somos filhos de Deus (Rm 8,15; Gl 4,6). Nisto somos chamados a reproduzir em nós mesmos a Imagem do Filho Único (Rm 8,29), pois fomos instituídos co-herdeiros com Ele (Rm 8,17). Assim somos filhos adotivos no Filho pela natureza e Deus nos trata como tais, inclusive quando tem que nos $\operatorname{corrigir}^{227}$ (Hb 12,5-12).

\subsection{O dualismo Espírito e carne}

Numa perspectiva bíblica, para o dualismo espírito-carne, podemos encontrar duas realidades ${ }^{228}$ : a primeira é uma profecia de Ez 37,5-10, onde o " $\pi v \varepsilon \tilde{u} \mu \alpha \zeta \omega \tilde{\eta} \varsigma$

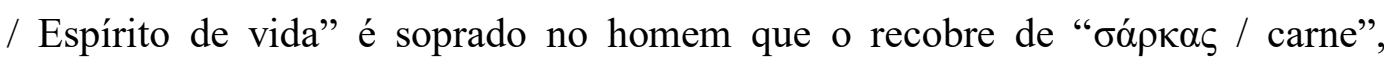

\footnotetext{
${ }^{227}$ X. LÉON-DUFOUR. Hijo de Dios, p. 386-387.

${ }^{228}$ O. CERFAUX. O Cristão na teologia de Paulo. São Paulo: Editora Teológica Ltda, 2003. p. 460.
} 
mostrando a situação de vida atual e antiga do homem. Já a segunda exprime o

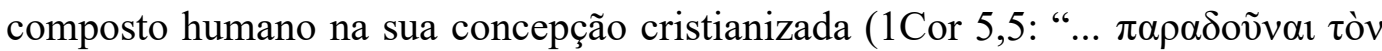

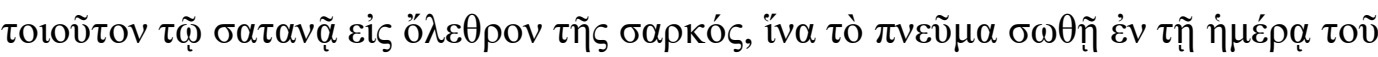
кupíov. / ... entreguemos tal homem a satanás para a perda da sua carne, a fim de que o espírito seja salvo no dia do Senhor").

\subsubsection{O dualismo}

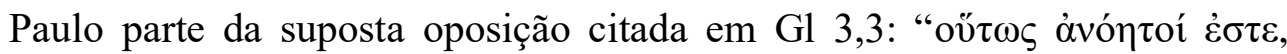

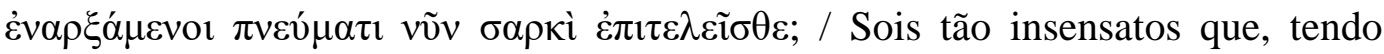
começado com o espírito, agora acabais na carne?” entre a prática da lei e as manifestações carismáticas dos cristãos, ou seja, a lei é a religião da carne, e a fé como seguimento de Cristo constitui a vida no Espírito. Ele procura demostrar a distinção espírito-carne com dois exemplos: o primeiro com os dois filhos de

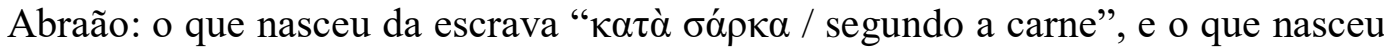

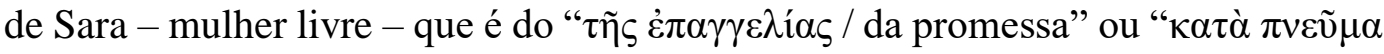
/ segundo o Espírito", que nasce em vista de Cristo. Assim, a mulher livre é a Jerusalém celeste e o povo antigo é o filho da escrava.

O segundo exemplo é uma comparação com a lei. A lei prescreve a

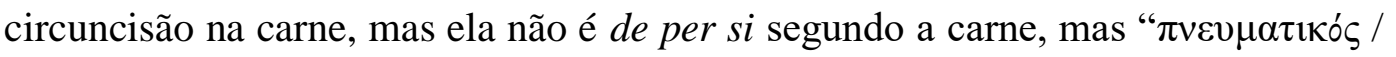
espiritual" enquanto representa a vontade de Deus, isto é, traz em si a promessa de Cristo, pois indica a direção que se deve tomar porque Deus fala através dela. A lei não foi compreendida porque permaneceu letra, ao passo que a intenção era divina (segundo o Espírito). Assim, o povo que vive segundo a carne, não a entende pois não submeteu à lei tal como Deus tinha querido, aberta para Cristo. Nisto o povo exaltou a letra da lei em detrimento do Espírito na qual havia sido criada ${ }^{229}$.

O ser na carne é o contrário de caminhar no Espírito ${ }^{230}$. A carne representa o ser humano na sua fraqueza, no seu egocentrismo, na sua autoafirmação, na sua

${ }^{229}$ L. CERFAUX. O Cristão na teologia de Paulo, p. 461-463.

${ }^{230}$ T. PAIGE. Spirito Santo. In: G.F. HAWTHORNE; R.P. MARTIN; D.G. REID. Dizionario di Paolo e delle sue Lettere, p. 1498. "Poiché l'umanità partecipa collettivamente della natura dell'Adamo caduto, la vita attuale del credente è caratterizzata dalla lotta, nel tempo che si estende tra i due eoni. L'influsso della vecchia natura non viene meno, anche se ora i credenti appartengono all'era futura, alla nuova umanità in Cristo. 'Anche noi, che possediamo le primizie dello Spirito, gemiamo interiormente aspettando l'adozione a figli, la redenzione del nostro corpo' (Rom 8,23). La redenzione di Cristo includerà quindi il rinnovamento completo anche dell'aspetto fisico, quando 
ignorância obstinada em oposição à vontade de Deus, ou seja, a sua humanidade em Adão que o leva à morte por causa dos desejos carnais. Contudo, com a certeza de que a carne foi redimida pela Morte e Ressurreição de Jesus, pode-se afirmar ainda que o cristão, mesmo sendo redimido, ele é de carne, vendido como escravo do pecado, tendo o seu corpo só parcialmente espiritualizado, pois Cristo condenou

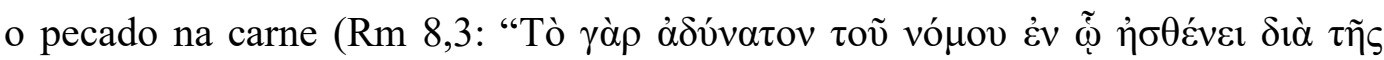

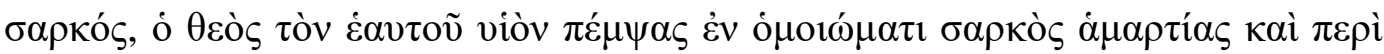

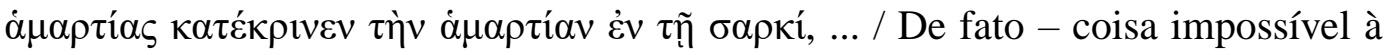
Lei, porque enfraquecida pela carne - Deus, enviando o seu próprio Filho numa carne semelhante à do pecado e em vista do pecado, condenou o pecado na carne,...") de modo que o homem continua submisso ao pecado se não aderir à vida no Espírito ${ }^{231}$, até o momento em que o corpo passe a ser totalmente espiritualizado na ressurreição da carne, à qual professamos e cremos. Paulo tem consciência desta fraqueza do homem e, por isso, numerosas vezes o instrui para não pecar ( Rm 6,1216; 8,12-14; 1 Cor 5,9-13; 6,18-20; 10,11-14.18-22.31; 2Cor 12,21; Gl 5,16-26) exortando a escolha da estrada que leva à vida no Espírito, porque somente "no Espírito se pode dizer que o cristão cumpre a lei"232 (Rm 8,1-4.12-15).

\subsubsection{A vitória do Espírito}

O Triunfo do Espírito sobre a carne no homem está ligado à sua vontade de viver segundo o Espírito. Teologicamente, o Espírito domina a carne com a vitória de Cristo na sua Morte e Ressurreição. Porém, a vitória se torna real contanto que os cristãos se entreguem a esta força e aceitem triunfar.

\footnotetext{
alla parusia i cristiani risusciteranno dai morti e riceveranno 'corpi spirituali' (1Cor 15,42-54; 2 Cor $5,1-5)$. D'altra parte, dovremmo prendere sul serio quanto Paolo afferma in Rom 8 , e cioè che una simile scelta della strada della vita, di camminare nello Spirito e di piacere a Dio, è veramente possibile nel tempo presente. Lo Spirito offre nuove possibilità agli uomini, e la sua presenza potente caratterizza la nuova esistenza, la quale è l'indicativo (ossia affermazione di una situazione di fatto) su cui si fonda l'imperativo etico. Non si tratta soltanto di credere in un contenuto oggeettivo e legale; secondo Paolo, questa vita nello Spirito deve tradursi in un impegno concreto in mezzo al mondo. Dice in Gál 5,16: Vi dico dunque: camminate secondo lo Spirito e non sarete portati a soddisfare i desideri della carne (Rom 8,4.12-17; 1Tes 1,4-10; 4,3-8)".

${ }^{231}$ T. PAIGE. Spirito Santo. In: G.F. HAWTHORNE; R.P. MARTIN; D.G. REID. Dizionario di Paolo e delle sue Lettere, p. 1497.

${ }^{232}$ T. PAIGE. Spirito Santo. In: G.F. HAWTHORNE; R.P. MARTIN; D.G. REID. Dizionario di Paolo e delle sue Lettere, p. 1498.
} 
Cerfaux ${ }^{233}$ diz que a vontade do homem era fraca pois estava lutando sozinha contra a carne, mas com o Espírito a vontade se fortalece. O Espírito unido ao nosso voũ cria em nós uma natureza renovada, dando-nos novas possibilidades.

Com toda a reflexão que fizemos a partir do apóstolo Paulo, podemos observar que a vida no Espírito é um dom de Deus, mas também é uma colaboração da nossa parte. Esse dom é manifestado no Amor gratuito de Deus Pai que veio a nós na sua liberdade por meio de seu único Filho Jesus, e na força do Espírito, para restaurar-nos da condição na qual vivíamos, condição essa que nos escravizava e não nos permitia viver a sua vida $(\operatorname{Rm} 6,1-11)^{234}$ e realizar a nossa vocação humana como imagem e semelhança de Deus. A ideia teológica que assim tentamos exprimir é indicada pela expressão "a colheita do Espírito”. O Espírito Santo está em nós como sementes; as sementes são a causa da colheita, mas esta não se faz sem o trabalho do homem, ou seja, depende do homem que pelo Espírito retomou a autonomia da sua vontade com intuito de usá-la para que, conduzido pelo mesmo Espírito, cumpra o desejo de Deus Pai em seu plano de Salvação.

\subsection{Filiação}

O fundamento teológico para a filiação divina daquele que crê está na filiação de Jesus, o Filho de Deus que veio ao mundo para salvar a humanidade. Schweiser afirma que a filiação se dá quando "Deus manda seu Filho (Rm 8,3s e Gl 4,4) para que, com sua morte seja desfeito a maldição e o sentido da força que a lei exercia

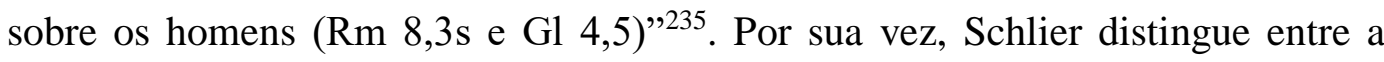
possibilidade de ser filhos e a realidade: "a primeira é dada com a vinda de Cristo; já a segunda com o batismo. Entretanto, se deve falar da realidade da filiação dada pela morte de Jesus e efetivada não só no batismo, mas na prática da vida de fé, na oração e na esperança"236.

\footnotetext{
${ }^{233}$ L. CERFAUX. O Cristão na teologia de Paulo, p. 458-459.

${ }^{234}$ Gostaria de sublinhar que quando falamos de vivermos a vida de Deus se trata de participação pelo Batismo na filiação adotiva, ou seja, filhos no Filho.

${ }^{235}$ E. SCHWEIZER. vios. In: G. KITTEL; G. FRIEDRICH. Grande Lessico del NT, vol. XIV, p. 252.

${ }^{236}$ SCHLIER apud E. SCHWEIZER. vios. In: G. KITTEL; G. FRIEDRICH. Grande Lessico del NT, vol. XIV, p. 252-253.
} 
É a partir da filiação que o cristão envolvido pelo Espírito clama a Deus com convicção e afeto de filho: Abba Pai! Essa verdade contrasta com o desejo de viver na carne e assim morrer pelo espírito de escravidão $(\operatorname{Rm~} 8,12.15)^{237}$. De fato, Paulo afirma na Carta aos Romanos que os cristãos não receberam um espírito de escravidão, mas um espírito de filiação, onde o mesmo Espírito afirma ao nosso ser que somos filhos. Essa afirmação é a base para a vida antecipada de novas criaturas, de filhos de Deus (Rm 8,14.19; 9,26; Gl 3,26; 4,6.7).

Em suma, a filiação nos faz participar do sofrimento de Cristo para que com Ele possamos ser glorificados. Ser de Cristo significa torna-se herdeiros de Deus e co-herdeiros, por Ele, de Deus Pai. E sendo assim, ao participarmos da sua glória recebemos a plenitude da filiação que em Cristo Jesus já havíamos experimentado antecipadamente na sua morte e ressureição pelo Batismo e adesão na fé.

\footnotetext{
${ }^{237}$ G. BRAY. La Biblia Comentada por los Padres de la Iglesia: Nuevo Testamento 6 - Romanos, p. 306-307: "Segundo Constancio no Comentario a la Carta a los Romanos: "Pablo enseña aqui com claridade que él no había tratado anteriormente de la muerte humana común y natural cuando dijo: $<<$ Pues si vívis según la carne, moriréis >>. Sino que se refiere a la muerte del castigo eterno; no es porque la carne humana sea mala y el espíritu sea bueno, por lo que alaba al espíritu y vitupera a la carne... Esto lo dice más bien queriendo probar que la mayor parte de las pasiones son ansias del cuerpo humano, que tenemos en común con los demás animales irracionales. Del mismo modo que los otros animales nacen de la tierra, así también el cuerpo que nosotros tenemos, pero nuestra alma es espiritual, incorpórea, racional e inmortal."
} 


\section{Conclusão}

Tentar refletir sobre a grande dádiva da filiação divina num contexto bíblico não é uma tarefa fácil por dois motivos particulares: primeiro, porque o mistério sempre vai muito além da nossa capacidade de refletir e exprimir; segundo, porque toda reflexão e dissertação depende de um estudo complexo dentro de vários ambientes de cogitação.

Iniciamos nosso itinerário tentando conhecer as questões preliminares que envolve o Sitz im Leben de Roma. Com o decorrer do estudo, e procurando conhecer a pessoa de Paulo, foi observado que na carta endereçada aos Romanos o apóstolo tinha em vista duas realidades: um desejo de estimular os membros judeus-cristãos a se abrirem ao universalismo do Evangelho contra toda forma de particularismo judaico ou judaísta ${ }^{238}$, uma vez que a comunidade de Roma já contava com a presença de gentios-cristãos; e escrever sua opus maius, isto é, seu testamento. Tendo em vista esses aspectos não resta dúvidas o quanto foi importante a cidade de Roma na visão do apóstolo, haja vista, sua intenção de realizar o seu projeto de evangelização na capital do Império.

Com a aplicação dos métodos histórico-crítico e retórico identificamos como está disposta a perícope de Rm 8,14-17. Um texto aparentemente simples, sem grandes problemas no seu aparato crítico que questionasse sua autenticidade, sem influências ad extra de fragmentos na sua confecção e estilo impresso do autor, e com enorme teor teológico Bíblico.

Através do comentário exegético, coração da nossa pesquisa, de acordo com os versículos escolhidos do capítulo 8 , chegamos à conclusão que de fato a mensagem que o apóstolo Paulo tinha proposto para a comunidade de Roma, e que serve também para cada um de nós, tem analogamente com o texto da TANAK um caráter exodal. Isto é, assim como o povo hebreu, que foi oprimido com a escravidão no Egito, celebrou sua páscoa, sendo liberado pelo poder de Deus, também todo aquele que crê e adere ao Cristo pelo batismo é liberado do domínio do pecado e da morte pela Páscoa definitiva realizada no Filho unigênito de Deus. No entanto, para participarmos desta vida nova precisamos nos deixar conduzir pelo Espírito Santo. Neste ponto vale ressaltar que a condução realizada pelo Espírito,

\footnotetext{
${ }^{238}$ R. PENNA. Lettera ai Romani, p. 43-50.
} 
representada pelo verbo "ó $\gamma o v \tau \alpha$ / ser conduzido" assume a voz média conforme defende Wilckens ${ }^{239}$. Ou seja, o cristão tem o compromisso de se deixar conduzir pelo Espírito e evitar a dimensão extática, através de uma ação conjunta entre quem conduz e quem se deixa conduzir.

Depois do caminho percorrido através da exegese se torna claro que a temática mais marcante no capítulo 8 é a pneumátologia. Nesta etapa da pesquisa observamos que o estado de vida que permite gritarmos ao Eterno Deus $A \beta \beta \dot{\alpha}$ Pai! é somente aquele pelo qual o Espírito Santo que vive dentro de nós, impulsiona a cada um a manter-se sob sua guia, e que pela Morte e Ressurreição de Cristo, obtivemos a dignidade de sermos filhos no seu Único Filho, Jesus Cristo. Por isso, entendemos imprescindível, na última parte do nosso estudo, fazer uma breve reflexão teológico-bíblica sobre o Espírito e a Filiação.

Nestas reflexões, identificamos que na condição de filhos de Deus, a vida do cristão tem sentido somente se vivida em Cristo na fé e através do seu Espírito: " $\delta i \alpha ̀$

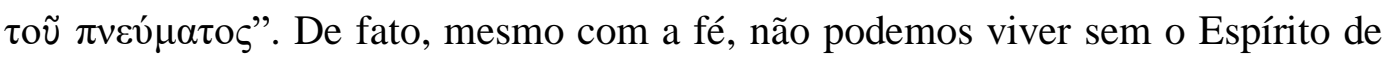

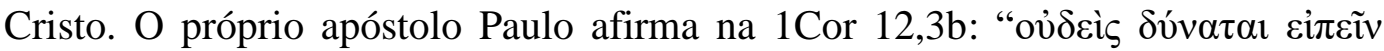

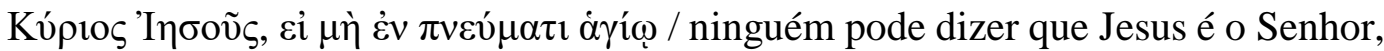
senão pelo Espírito Santo”. É o Espírito Santo que transforma a nossa vida, e é Ele que, através do batismo, nos dá a dignidade de sermos filhos de Deus e a capacidade de frear as forças dinâmicas da carne, mortificando assim as concupiscências e negando o pecado. É o Espírito Santo que modela o ícone do Filho em nós

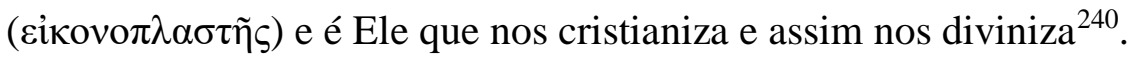

Contudo, esperamos que nossa dissertação, embora não apresente uma novidade, possa motivar os pesquisadores a continuarem, com a ajuda do Espírito Santo e o esforço pessoal, a desvelar, na medida do possível, e permitido por Deus, a Beleza e a riqueza deste maravilhoso mundo que é a Sagrada Escritura, palavra do Eterno Pai que quis comunicar aos seus filhos e filhas o seu Amor.

\footnotetext{
${ }^{239}$ U. WILCKENS. La Carta a los Romanos 6-16 (II), p. 169.

240 A.M. GARCÍA. La sabiduría del Espíritu és Biogéna. Hacia una Sintaxis de la alteridad (Rom 8,6 y Flp 2,2). Bible (NT)- Romans 5-8. Madrid: Estudios Bíblicos 60, 2002, p. 15.
} 


\section{Referências Bibliograficas}

\subsection{Fontes}

BÍBLIA. Bíblia de Jerusalém. São Paulo: Paulus, 1995.

BÍBLIA. Bíblia Tradução Ecumênica. São Paulo: Edições Loyola, 1994

KITTEL, R.; ELLIGER, K.; RUDOLPH, W.; RUGER, H.P.; WEIL, G.E. Biblia Hebraica Stuttgartensia. Editio Funditus Renovata. Stuttgart: Deutsche Bibelstiftung, 1990.

NESTLE, E.; ALAND, K. Novum Testamentum Graece. 28. Rev. Aufl. Stuttgart: Deutsche Bibelgesellschaft, 2012.

RAHLFS, A.; HANHART, R. Septuaginta. Id est Vetus Testamentum graece iuxta LXX interpretes. Editio altera. Stuttgart: Deutsche Bibelgesellschaft, 2006.

7.2 Comentários e obras diversas

ALETTI, J.N. Romanos: Comentario Bíblico Internacional. Estella (Navarra): W.R. Farmer, 1999, p. 1416-1458.

ALEXANDER, L.C.A. Cronologia di Paolo. In: HAWTHORNE, G.F.; MARTIN, R.P.; REID, D.G. Dizionario di Paolo e delle sue Lettere. Cinisello Balsamo: San Paolo Edizioni, 2000, p. 408-421.

ALTHAUS, P. La Lettera ai Romani. Brescia: Paideia Editrice, 1970.

AUNE, D.E. Imperatori Romani. In: HAWTHORNE, G.F.; MARTIN, R.P.; REID, D.G. Dizionario di Paolo e delle sue Lettere. Cinisello Balsamo: San Paolo Edizioni, 2000, p. 847-850.

BALZ, H. фóßos. In: BALZ, H.; SCHNEIDER, G. Dizionario Esegetico del NT. Brescia: Paideia Editrice, 2004, p. 1814-1819.

BALZ, H.; SCHNEIDER, G. a cura di O. SOFFRITTI. Dizionario Esegetico del NT. Brescia: Paideia Editrice, 1995, 2004².

BARBAGLIO, G. La persona e l'opera di Paolo. In: SACCHI, A. - et al., ed., Lettere Paoline e altre Lettere. LCSB 6. Torino: Elledici, 1996, p. 53-68.

BARBAGLIO, G. La teologia di Paolo. Bologna: EDB, 1999.

BARBAGLIO, G. Le Lettere di Paolo, I-III. Roma: Borla, 1980. 
BETZ, H.D. өєós. In: BALZ, H.; SCHNEIDER, G. Dizionario Esegetico del NT. Brescia: Paideia Editrice, 2004, p. 1612-1619.

BLASS, F.; DEBRUNNER, A. A Greek Grammar of the New Testament and Other Early Christian literature. Chigago: The University of Chicago Press, 1961.

BORSE, U. ớ $\gamma \omega$. In: BALZ, H.; SCHNEIDER, G. Dizionario Esegetico del NT. Brescia: Paideia Editrice, 2004, p. 64-65.

BOTTERWECK, G.J.; RINGGREN, H.; eda cura di P.G. BORBONE. Grande Lessico dell'AT Brescia: Paideia Editrice, 2003.

BRAY, G. La Biblia Comentada por los Padres de la Iglesia: NT 6 - Romanos. Madrid: Ciudad Nueva, 2000, p. 306-307.

BRODEUR, S. La dimensione escatologica de la morale cristiana in Rom 8. StMor 36. Roma: Editore Pontificia Università Gregoriana, 1988, p. 393-419.

BRUCE, F.F. Romanos: Introdução e comentário. São Paulo: Vida Nova, 1979.

CERFAUX, L. O Cristão na teologia de Paulo.São Paulo: Editora Teológica Ltda, 2003.

CIPRIANI, S. Epistola ai Romani. In Introduzione alla Bibbia, I. Milano: San Paolo Edizioni, 1966, p. 405-502.

COENEN, L.; BEYREUTHER, E.; BIETENHARD, H.; et al. a cura di A. DAL BIANCO - B. LIVERANI - G. MASSI. Dizionario dei Concetti Biblici del NT. Bologna: EDB, 1976.

CRAFTON, J.A. Paul's Rhetorical Vision and the Purpose of Romans. Toward a New Understanding. NT 32. Evanston, Il: Biblical studies, 1990, p. 317339.

CRANFIELD, C.E.B. Carta aos Romanos. GCB. São Paulo: Paulinas, 1992.

DRANE, J.W. Why Did Paul Write Romans? In: HANGER, D.A.; HARRIUS, M.J. ed. Exeter: Pauline Studies, 1980, p. 208-227.

DUNN, J.D.G. A teologia do apóstolo Paulo. São Paulo, Paulus, 2003.

DUNN, J.D.G. Jesus y el Espíritu. La experiencia carismática de Jesús y sus Apóstoles. Barcelona: Editorial Clie, 2014.

DUNN, J.D.G. Lettera ai Romani. In: HAWTHORNE, G.F.; MARTIN, R.P.; REID, D.G. Dizionario di Paolo e delle sue Lettere. Cinisello Balsamo: San Paolo Edizioni, 2000, p. 1353-1375.

DUNN, J.D.G. Romans 1-8. WBC 38. Dallas: Word Books, 1988. 
FENDRICH, H. крáと๘. In: BALZ, H.; SCHNEIDER, G. Dizionario Esegetico del NT. Brescia: Paideia Editrice, 2004, p. 90-92.

FITZMYER, J.A. La Lettera ai Romani: Commentario critico-teologico. Casale Monferrato: Edizioni Piemme, 1999.

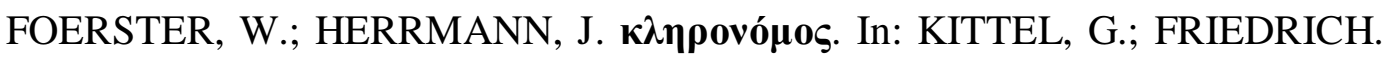
G. Grande Lessico do NT, vol. V, Brescia: Paideia Editrice, 1969, p. 611-663.

FREEDMAN, D.N. ירזֶרה . In: BOTTERWECK, G.J.; RINGGREN, H. Grande Lessico dell'AT, vol. III. Brescia: Paideia Editrice, 2003, p. 621-622.

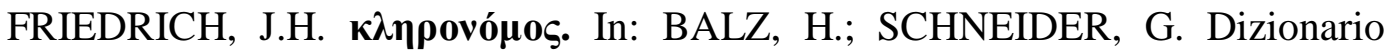
Esegetico del NT. Brescia: Paideia Editrice, 2004, p. 49-52.

GARCÍA, A.M. La Sabiduría del Espíritu es Biógena. Hacia una Sintaxis de la alteridad (Rom 8,6 y Flp 2,2). Bible (NT)- Romans 5-8. Madrid: Estudios Bíblicos 60, 2002, p. 3-30.

GONZAGA, W.A. Sagrada Escritura, a Alma da Sagrada Teologia. In: MAZZAROLO, I.; FERNANDES, L.A.; LIMA, M.L.C. Exegese, Teologia e Pastoral: relações, tensões e desafios. Santo André: PUC-Rio Academia Cristã, 2015, p. 201-235.

GUTHRIE, D.; MARTIN, R.P. Dio. In: HAWTHORNE, G.F.; MARTIN, R.P.; REID, D.G. Dizionario di Paolo e delle sue Lettere. Cinisello Balsamo: San Paolo Edizioni, 2000, p. 445-468.

HAHN, F. viós. In: BALZ, H.; SCHNEIDER, G. Dizionario Esegetico del NT. Brescia: Paideia Editrice, 2004, p. 1687-1713.

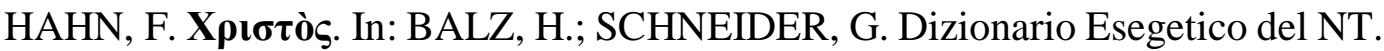
Brescia: Paideia Editrice, 2004, p. 1933-1953.

HANSEN, G.W. Critica Retorica. In: HAWTHORNE, G.F.; MARTIN, R.P.; REID, D.G. Dizionario di Paolo e delle sue Lettere. Cinisello Balsamo: San Paolo Edizioni, 2000, p.384.

HAWTHORNE, G.F.; MARTIN, R.P.; REID, D.G. Dizionario di Paolo e delle sue Lettere. Cinisello Balsamo: San Paolo Edizioni, 2000.

HENDRIKSEN, W. Comentário do NT - Romanos. São Paulo: Editora Cultura Cristã, 2011.

HENGEL, M. Il Paolo precristiano. SB 100. Brescia: Paideia Editrice, 1992.

HOLTZ, T. oṽ்os. In: BALZ, H.; SCHNEIDER, G. Dizionario Esegetico del NT. Brescia: Paideia Editrice, 2004, p. 691-692. 
HURTADO, L.W. Figlio di Dio. In: HAWTHORNE, G.F.; MARTIN, R.P.; REID, D.G. Dizionario di Paolo e delle sue Lettere. Cinisello Balsamo: San Paolo Edizioni, 2000, p. 615-626.

JEREMIAS, J. A $\beta \beta \dot{\alpha}$. Supplmenti al Grande Lessico del NT. Brescia: Paideia Editrice, 1968.

KAMLAH, E. Spirito. In: COENEN, L; BEYREUTHER, E.; BIETENHARD, H.; et al. Dizionario dei Concetti Biblici del NT. Bologna: EDB, 1976, p. 1791.

KERTELGE, K. A Epístola aos Romanos. Petrópolis: Vozes, 1982.

KITTEL, G. A’ $\boldsymbol{\beta} \boldsymbol{\beta}$ ó. In: KITTEL, G.; FRIEDRICH. G. Grande Lessico del NT, vol. I. Brescia: Paideia Editrice. 1965, p. 15-18.

KITTEL, G.; FRIEDRICH, G. et al. Grande Lessico del NT, I-XVI. p. 1965-1992.

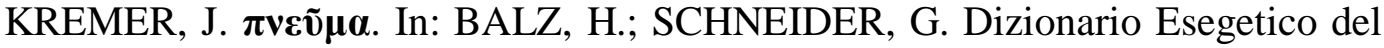
NT. Brescia: Paideia Editrice, 2004, p. 1009-1011.

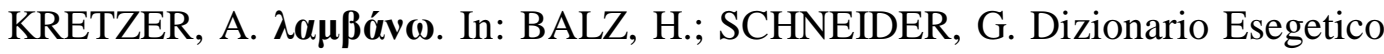
del NT. Brescia: Paideia Editrice, 2004, p. 148-152.

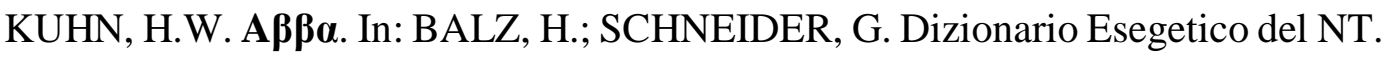
Brescia: Paideia Editrice, 2004, p, 1-3.

LAGRANGE, J.M. Saint Paul: L'Épître aux Romains. Paris: Etudes Bibliques 1916, XVIII-XX.

LEENHARDT, F.J. L'Épître de St. Paul aux Romains. Neuchâtel-Paris: Desclée de Brouwer, 1962.

LÉGASSE, S. L’Ếpître de Paul aux Romains. Paris: Cerf, 2002.

LÉGASSE, S. Paolo Apostolo: Biografia crítica. Roma: Città Nuova, 1994.

LEON-DUFOUR, X. Vocabulario de Teología Bíblica. Barcelona: Editorial Herder, S.A., $1996^{17}$.

LIMA, M.L.C. Exegese Bíblica: teoria e prática. São Paulo: Paulinas, 2014.

MAPILA, M. Glosarios de numismática antiga. In: http://www.tesorillo.com/roma/1tipos.htm\#D,2006, [acesso em: 11/07/2017].

MAZZAROLO, I. A Carta aos Romanos: Educar para a maturidade e o amor. Rio de Janeiro: Mazzarolo Editor, 2006.

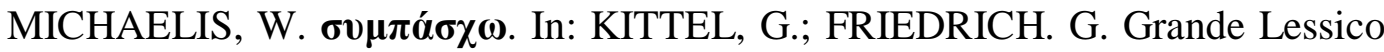
del NT, vol. XII. Brescia: Paideia Editrice, 1974, p. 1046-1051. 
MILlOS, S.P. Romanos: Comentario Exegético al Texto Griego del NT. Barcelona: Editorial Clie, 2011.

MÜLLER, P.G. ov̉. In: BALZ, H.; SCHNEIDER, G. Dizionario Esegetico del NT. Brescia: Paideia Editrice, 2004, p, 667-669.

MURPHY-O'CONNOR, J.P. Vita di Paolo. Introduzione allo Studio della Bibbia, Supplementi 13. Brescia: Editrice Paideia, 2003.

OBERMAYER, et. al. Paolo. In: OBERMAYER, H.; SPEIDEL, K.; VOGT, K., et. al. ed. Piccolo Dizionario Biblico. Cinisello Balsamo: San Paolo Edizioni, 1997, p. 238-240.

OBERMAYER, H. et. al. Paraclito. In: OBERMAYER, H.; SPEIDEL, K.; VOGT, K.; et. al. ed. Piccolo Dizionario Biblico. Cinisello Balsamo: San Paolo Edizioni, 1997, p. 242.

OBERMAYER, H. et. al. Spirito. In: OBERMAYER, H.; SPEIDEL, K.; VOGT, K.; et. al. ed. Piccolo Dizionario Biblico. Cinisello Balsamo: San Paolo Edizioni, 1997, p. 305-306.

OBERMAYER, H.; SPEIDEL, K.; VOGT, K.; et. al. Ed. a cura di A. MINISSALE. Piccolo Dizionario Biblico. Cinisello Balsamo: San Paolo, 1988, $1997^{7}$.

PAIGE, T. Spirito Santo. In: HAWTHORNE, G.F.; MARTIN, R.P.; REID, D.G. Dizionario di Paolo e delle sue Lettere. Cinisello Balsamo: San Paolo Edizioni, 2000, p. 1489-1504.

PENNA, R. I Ritratti originali di Gesù il Cristo: Inizi e sviluppi della cristologia neotestamentaria, I. Gli sviluppi, Studi sulla Bibbia e il suo Ambiente. Cinisello Balsamo: San Paolo Edizioni, 1996, 2001².

PENNA, R. Lettera ai Romani: Rm 1-5 (I). Scritti delle origini Cristiane 6 . Bologna: Edizioni Dehoniane Bologna, 2004.

PENNA, R. Lettera ai Romani: Rm 6-11 (II). Scritti delle origini Cristiane 6. Bologna: Edizioni Dehoniane Bologna, 2006.

PENNA, R. Non uno spirito da schiavi per ricadere nella paura $(\mathbf{R m} 8,15)$. $P S V$ : quaderni di lettura bíblica 33 - La paura. Bologna: EDB, 1996, p. 147-161.

PERROT, C. Epístola aos Romanos. São Paulo: Edições Paulina, 1993.

PITTA, A. Disposizione e messaggio della Lettera ai galati. Analisi retoricoletteraria. Analecta Biblica. Roma: Editore Pontificia Università Gregoriana, 1992.

PITTA, A. Lettera ai Romani: Nuova versione, introduzione e commento. LBNT 6. Milano: San Paolo, 2001. 


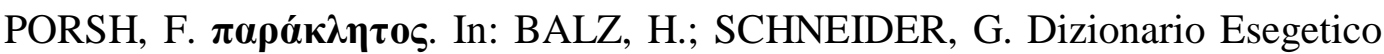
del NT. Brescia: Paideia Editrice, 2004, p. 778-781.

PRIDIK, K. H. yò $\rho$. In: BALZ, H.; SCHNEIDER, G. Dizionario Esegetico del NT. Brescia: Paideia Editrice, 2004, p. 628-630.

RADL, W. őбos. In: BALZ, H.; SCHNEIDER, G. Dizionario Esegetico del NT. Brescia: Paideia Editrice, 2004, p. 661-663.

RAVASSI, G.F. La Lettera ai Romani. Bologna: Edizioni Dehoniane Bologna, 1990.

REASONER, M. Roma e il cristianesimo romano. In: HAWTHORNE, G.F.; MARTIN, R.P.; REID, D.G. Dizionario di Paolo e delle sue Lettere. Cinisello Balsamo: San Paolo Edizioni, 2000, p.1345-1353.

RENARD, H.; GRELOT, P. Hijo de Dios. In: LÉON-DUFOUR, X. Vocabulario de Teología Bíblica. Barcelona: Herder, 1965, 1966, p. 384-387.

RICCIOTTI, G. Paolo Apostolo: Biografia con Introduzione Crítica. Roma: Coletti Editore, 1958.

RUPPRECHT, A.A. Schiavo, schiavitù. In: HAWTHORNE, G.F.; MARTIN, R.P.; REID, D.G. Dizionario di Paolo e delle sue Lettere. Cinisello Balsamo: San Paolo Edizioni, 2000, p. 1416-1419.

SACCHI, A. La cronologia Paolina. In: A. SACCHI et al. ed. Lettere Paoline e altre Lettere. LCSB 6. Torino: Elledici, 1996, p. 61-68.

SACCHI, A. Lettera ai Romani. NT - esegetico e spirituale. Roma: Città Nuova, 2000.

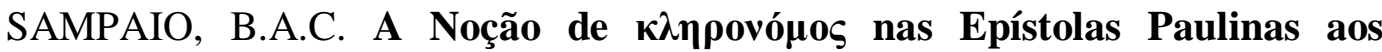
Romanos e aos Gálatas. Thesis as Doctoratum in Theologia totaliter edita. Roma: Pontificia Universitas Sanctae Crucis, 2000.

SANCHEZ BOSCH, J. Escritos paulinos. IEB 7. Estalla (Navarra): Editorial Verbo Divino, 1998.

SCHLIER, H. La Lettera ai Romani. Brescia: Paideia Editrice, 1982.

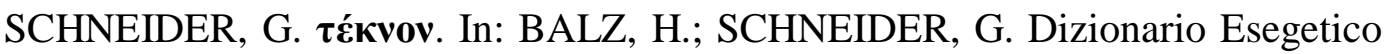
del NT. Brescia: Paideia Editrice, 2004, p. 1584-1587.

SCHWEIZER, E. viós. In: KITTEL, G.; FRIEDRICH, G. Grande Lessico do NT, vol. XIV. Brescia: Paideia Editrice, 1984, p. 247-254.

SPREAFICO, A. EI Libro del Éxodo. Barcelona: Editorial Herder, 1995. 
STENDAHL, K. Paolo tra ebrei e pagani. Picolla Collana Moderna, Serie Teologica 74. Torino: Claudiana Editrice, 1995.

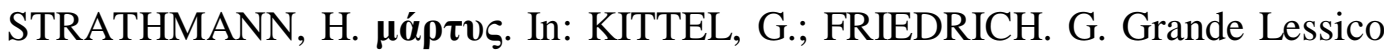
del NT, vol. VI. Brescia: Paideia Editrice, 1970, p. 1269-1372.

STRATHMANN, H. $\boldsymbol{\sigma} \boldsymbol{\mu} \mu \boldsymbol{\mu} \boldsymbol{\tau} \boldsymbol{\rho} \rho \tilde{\varepsilon}$. In: KITTEL, G.; FRIEDRICH. G. Grande Lessico del NT, vol. VI. Brescia: Paideia Editrice, 1970. p. 1374-1377.

TORTI, G. La Lettera ai Romani. SB 41. Brescia: Paideia Editrice, 1977.

VANNI, U. Lettera ai Galati e ai Romani. Torino: Claudiana, 1989, 72.

VANNI, U. L'ebbrezza nello Spirito. Roma: Edizioni ADP, 2000.

VANNI, U. Lo Spirito e la libertà secondo Paolo. PSV: quaderni di lettura bíblica 4 - lo Spirito del Signore. Bologna: EDB, 1979, p. 173-185.

VASCONCELOS, F.A. Abba ho Patēr e Syn-Construtos: Formas de Antitéticas à Idolatria/Sincretismo em Rm 8,14-17. Doutorado (Teologia Bíblica). Rio de Janeiro: Pontíficia Universidade Católica do Rio de Janeiro, 2013.

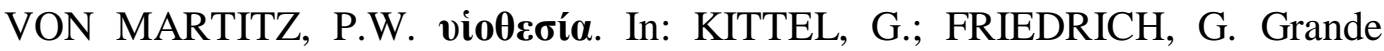
Lessico del NT, vol. XIV. Brescia: Paideia Editrice, 1984, p. 268-271.

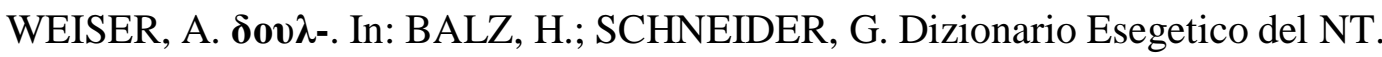
Brescia: Paideia Editrice, 2004, p. 926-936.

WILCKENS, U. La Carta a los Romanos 6-16 (II). BEB 61, 62. Salamanca: Ediciones Sigueme, 1992.

WINTER, B. W. Retorica. In: HAWTHORNE, G.F.; MARTIN, R.P.; REID, D.G. Dizionario di Paolo e delle sue Lettere. Cinisello Balsamo: San Paolo Edizioni, 2000, p. 1326-1328.

ZEDDA, S. Prima lettura di S. Paolo. Brescia: Paideia Editrice, 1963, $1973^{5}$.

ZELLER, D. Lettera ai Romani. Brescia: Paideia Editrice, 1998. 